\title{
Eolian dust influx and massive whitings during the kozlowski/Lau Event: carbonate hypersaturation as a possible driver of the mid-Ludfordian Carbon Isotope Excursion
}

\author{
WOJCIECH KOZŁOWSKI
}

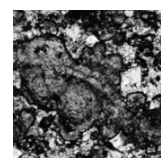

\begin{abstract}
The mid-Ludfordian Carbon Isotope Excursion (CIE) is one of the biggest perturbation in the isotope and facies record in the Palaeozoic. However, its causes still remain unknown. In the periplatform setting of the Baltica palaeocontinent the event interval contains rock-forming minute calcite crystals, interpreted here as suspension-originated analogues of recent whitings and calcite rafts. The grains were preferentially formed around picocyanobacterial filaments, which are preserved as tubes inside. An event-related, 9 m-thick, massive calcisiltite bed points to the persistent hypersaturated state conditions (HSS) during the increasing limb of the CIE. The studied interval contains also a significant admixture of minute-sized detrital dolomite grains, appear for the first time several meters below and reach peak abundance immediately below the calcisiltite interval. The dolomite grains show consistent $\delta^{13} \mathrm{C}$ values $(\sim 0 \%)$ across the CIE. Their record is decoupled from the bulk-rock $\mathrm{C}$-isotope record and thus indicates overwhelmingly pre-sedimentary formation and extrabasinal provenance of the dolomite. The size and provenance of the grains, along with their incorporation into surface water precipitates and formation of specific very thin laminas with internal density gradation of grains (dolomite-quartz couplets), suggest the eolian delivery of the grains to the basin. The dust influx pulses seem to have triggered the calcite precipitation events. Furthermore, the size-frequency distribution of the pyrite framboids across the studied interval shows that the progressing dust influx was followed by persistent euxinia occurring right before and during the increasing limb of the CIE. In the proposed model, globally enhanced eolian delivery of iron during the assumed glaciation promoted high net pyrite formation. The resulting "sulphate to bicarbonate exchange", a hypothetical dissolution of eolian carbonate dust particles in deep basins, a concurrent bicarbonate supply from the carbonates emerged due to the sea-level fall, and a parallel cessation of the carbonate factory (exposed carbonate platform tops), raised the alkalinity and formed the global carbonate hypersaturated state (HSS) of the ocean. The processes needed largescale invasion of the $\mathrm{CO}_{2}$, consumed in the ocean by bicarbonate formation processes. It is hypothesized that during the subsequent initial transgression, the HSS was discharged by massive carbonate precipitation. The rapid "carbonate reflux" returned the earlier uptaken $\mathrm{CO}_{2}$ to the atmosphere by fast degassing. Its fast transfer resulted in the globally synchronized, kinetic, residual, ${ }^{13} \mathrm{C}_{\mathrm{DIC}}$-enrichment of water pools localized over individual carbonate platforms. During "carbonate reflux", the local CIE amplitude depended on the carbonate production rate, water column thickness and pool residence time. Key words: eolian dust, saturation state, carbon isotope excursion (CIE), carbon cycle, euxinia, whitings, picocyanobacteria, Lau Event, Silurian.
\end{abstract}

KozŁOWSKI, W. 2015. Eolian dust influx and massive whitings during the kozlowski/Lau Event: carbonate hypersaturation as a possible driver of the mid-Ludfordian Carbon Isotope Excursion. Bulletin of Geosciences 90(4), 807-840 (10 figures, 2 tables). Czech Geological Survey, Prague. ISSN 1214-1119. Manuscript received July 15, 2015; accepted in revised form September 16, 2015; published online November 3, 2015; issued November 30, 2015.

Wojciech Kozłowski, Faculty of Geology, University of Warsaw, Żwirki i Wigury Str. 93, PL-02-089 Warsaw, Poland; woko@uw.edu.pl

The Silurian contains several minor mass extinctions, coupled with the recurrence of pronounced perturbations in the facies and geochemical record (summarized in Munnecke et al. 2010). The events show several common features (Munnecke et al. 2003) and seem to be linked with sudden repetitions of minor glaciations in polar regions (Kaljo et al. 2003, Cherns \& Wheeley 2009). In tropical carbonate platform successions, the perturbations are expressively manifested as pronounced Carbon Isotope Excursions (CIEs; Samtleben et al. 1996, Bickert et al. 1997). Similarly as the other excursions, the most pronounced mid-Ludfordian CIE (up to $+11.21 \%$ o PDB - WigforssLange 1999) is associated with an abrupt sea-level fall and distinct anomalies in the facies record (Calner 2008, 
Munnecke et al. 2010). The combined sedimentary, palaeontological and geochemical anomalies observed in this interval are often named after coincident minor extinction of graptolites and conodonts and referred to as the kozlowski/Lau Event (Urbanek 1993, Jeppsson 1990, Calner 2005a, Jeppsson et al. 2007). Coeval glacial deposits have not been recognized in high palaeolatitudes (Cherns \& Wheeley 2009), although a presumed minor glaciation is postulated in this interval, based on rapid sea-level drop, coeval with a positive oxygen isotope excursion noted in the bioapatite record (Lehnert et al. 2007a).

Despite the broad identification of the early Palaeozoic CIEs, the mechanism of their recurrent formation remains the subject of debate (e.g. Loydell 2007, Cramer \& Munnecke 2008, Holmden et al. 2012, Kozłowski \& Sobień 2012, Frýda \& Manda 2013, Ghienne et al. 2014) and to date several models have been proposed (summarized in Calner 2008, Munnecke et al. 2010, Ghienne et al. 2014). Early Palaeozoic CIEs appear to coincide with perturbations in the isotopic record of sulphur (e.g. Yan et al. 2009, Gill et al. 2011), nitrogen (LaPorte et al. 2009), and calcium (Holmden et al. 2012), hence represent only part of the pronounced perturbations in the seawater chemistry.

One of the briefly considered driving mechanisms of the mid-Ludfordian event was the enhanced calcite saturation state $(\Omega)$ of the ocean (Riding 2005). This supposition was based on the widely observed abundant occurrence of microbial carbonates (Calner 2005a), which throughout much of the Phanerozoic reveal a broad positive correspondence with the calculated $\Omega$ (Riding \& Liang 2005a). The interpretation seems be supported by the extensive development of reefs (Brunton et al. 1998) and carbonate platforms, with the often abundant formation of non-skeletal grains (Munnecke et al. 2003, 2010), coeval with the Silurian CIEs. A direct link between the mid-Ludfordian environmental perturbations and the presumed hyper-saturation state has been dismissed (Calner 2005b, Munnecke et al. 2010), because global changes in $\Omega$ are regarded as long-term processes (Riding \& Liang 2005a, b), whereas the mid-Ludfordian CIE is relatively short-lived (Calner 2005b).

The studied event, from the beginning of its studies, is seen as a period of pronounced arid conditions in low latitudes (Bickert et al. 1997). This primary belief was soon supported by findings of thin laminae of silt-sized terrigenous material in limestones, interpreted as eolian dust (Samtleben et al. 2000), and additionally the high abundance of terrestrial spores in marine sedimentary rocks in the CIE interval in Gotland (Stricanne et al. 2006).

Despite the broad documentation of the event in shallow-water successions, its deep shelf facies record remains insufficiently recognized. In the axial part of the SW Baltica Caledonian foreland basin, the event is marked by the widespread, pronounced negative natural gamma-ray excursion coupled with an unusually low magnetic susceptibility of the sedimentary rocks (Kozłowski \& Sobień 2012, Porębski et al. 2013). According to Kozłowski \& Sobień (2012), both lows are caused by a pronounced facies anomaly in the form of regionally widespread event bed composed of very fine carbonate silt. XRD bulk-rock analysis, along with the observation of the predominance of rhomb-shaped euhedral grains in thin sections, suggested that the carbonate silt is composed of dolomite (Kozłowski \& Sobień 2012). The silt size and common sorting observed in the quartz and rhomboidal grains imply an interpretation of the airborne origin of the detritus, by analogy to the wind-derived dolomite admixture to marine sediments in recent low-latitude, arid regions (e.g. in Persian Gulf - Khalaf et al. 1979).

In the last years, eolian dust has been considered a key player in the evolution of the global climate state, ocean biogeochemistry (summarized in Maher et al. 2010), bioproductivity (e.g. Rao et al. 1999) and even precipitation of carbonate sediments (Swart et al. 2014). Eolian dust has a widespread, well known record in the Quaternary, but its occurrence as a significant component of ancient sedimentary rocks has rarely been emphasized (but see Soreghan \& Soreghan 2002). Despite a general supposition that the early Palaeozoic climate should be much dustier than that of the present day, unequivocal indications of eolian material in lower Palaeozoic marine sedimentary rocks are very limited (e.g. Gabbott et al. 2010).

The aim of this work is a multi-proxy study of the mid-Ludfordian CIE interval in the deep-water, periplatform succession of the Mielnik IG-1 section in eastern Poland, improving and extending the earlier (Kozłowski \& Sobień 2012) description and classification of the event-related, peculiar carbonate grain assemblage. The microfacies study was focused on textural features potentially useful for examining the presumed eolian derivation of the grains. The newly obtained isotope signatures of the extracted dolomite grains and bulk-rock carbon isotope data of Kozłowski \& Sobień (2012) have been compared across the isotope excursion to test for the extrabasinal derivation of the dolomite component. Semi-quantitative mineralogical studies (XRD) across the event interval have been performed to explore the dolomite derivation history and its relation to the CIE record. Because of the possible influence of presumed eolian delivery on the bioproductivity, the redox conditions were investigated based on the statistics of the framboidal pyrite spheroids. For extracting the autochthonous CIE record, approximate carbon isotope signatures have been calculated for the clear calcite component, based on the obtained calcite/dolomite ratio (XRD) combined with the dolomite and bulk-rock carbon isotope data.

This paper describes a peculiar carbonate grain assemblage appearing in the studied section exclusively in the 
kozlowski/Lau Event interval. In addition to detrital dolomite, the interval contains previously not recognized rock-forming calcite grains interpreted here as the water column precipitates. This mass occurrence reinforces the earlier suggestions of a hypersaturated state during the event. The reconstructed scenario of the event in the studied succession suggests possible close links between glaciations, eustacy, dustiness, formation of euxinic conditions, calcite saturation state, carbonate precipitation and formation of isotopically heavy carbonates. Based upon the present observations as well as earlier models, a new hypothetic mechanism of CIE formation is proposed.

\section{Outline of the kozlowski/Lau Event record}

The studied event is coeval with a pronounced, globally recorded, presumably glacieustatic sea-level lowstand (Kaljo et al. 2003, Kozłowski 2003, Jeppsson et al. 2007, Lehnert et al. 2007b, Eriksson \& Calner 2008, Brett et al. 2009, Kozłowski \& Munnecke 2010). In the outer parts of ramps, the mid-Ludfordian CIE starts with an abrupt facies change from shales to carbonates, with a shallowing-upward trend observed across the CIE interval (Jeppsson et al. 2007, Lehnert et al. 2007a, Brett et al. 2009, Martma et al. 2010, Frýda \& Manda 2013). However, the inner-ramp successions, containing a well-defined proximal sequence boundary (SB), record a pronounced unconformity near the base of the rapidly increasing limb of the CIE (Barrandian Mušlovka: Lehnert et al. 2007b, Gotland: Eriksson \& Calner 2008, Holy Cross Mountains: Kozłowski \& Munnecke 2010). According to these observations, the mid-Ludfordian CIE starts with the beginning of early transgressive conditions, following a substantial forced regression (Eriksson \& Calner 2008, Kozłowski \& Munnecke 2010). Above the SB and the initial flooding events, the transgressive trend is relatively slow, which causes a normal regression observed in the facies record (Kozłowski \& Munnecke 2010), with a possible additional minor sea-level drop near the end of the CIE maximum (Eriksson \& Calner 2008).

The mid-Ludfordian CIE follows a minor extinction of pelagic fauna (conodonts: Jeppsson \& Aldridge 2000; graptolites: Kříž 1991, Urbanek 1993, and pentamerid brachiopods: Talent et al. 1993). Despite the near-coincidence of the extinction and the CIE, an expected anoxic event, synchronous with the CIE, recorded as black shales in deep-water settings, is not observed (Munnecke et al. 2003, 2010; but see also Antoshkina et al. 2012). On the other hand, argillaceous beds occurring just below the carbonate-bearing CIE interval show a relatively high contribution of organic matter (Samtleben et al. 2000, Lehnert et al. 2007a, Eriksson \& Calner 2008) and most probably represent widespread occurrence of anoxic conditions (Brett et al. 2009) in the interval referred to the "Cardiola Event" (Schönlaub 1986).
The mid-Ludfordian facial anomaly (as with other Silurian CIE-related events - Munnecke et al. 2003, 2010) is characterized by the widespread expansion of reefs (Brunton et al. 1998) and carbonate platforms (Frýda \& Manda 2013). The broad occurrence of microbial carbonates (Calner 2005a) is represented by open-marine stromatolites (Cherns 1982, Calner 2005c, Antoshkina 2014) and the mass occurrence of oncoids (WigforssLange 1999, Samtleben et al. 2000, Arp et al. 2001, Calner 2005c, Jeppsson et al. 2007, Brett et al. 2009, Kozłowski \& Munnecke 2010). The event interval contains unusual, globally widespread appearances of oolites (Stel \& de Coo 1977, Kozłowski 2003, Calner 2005c, Jeppsson et al. 2007, Wigforss-Lange 2007, Eriksson \& Calner 2008, Barrick et al. 2010).

The mid-Ludfordian CIE is correlable between various palaeocontinents, and across low and middle palaeolatitudes (Talent et al. 1993; Jeppsson et al. 2007, 2012; Lehnert et al. 2007b). Paradoxically, one of the crucial features of the Silurian CIEs is the laterally differentiated amplitude of the excursion with a basinward decline (Loydell 2007), coexisting with the synchronous appearance of the excursion (Cramer et al. 2010) and certain for each event maximal $\delta^{13} \mathrm{C}$ values (see fig. 7 in Frýda \& Manda 2013).

In the case of the mid-Ludfordian CIE, the maximum $\delta^{13} \mathrm{C}$ values have been noted (Wigforss-Lange 1999) in the shallowest zone of the semi-enclosed (Baltic) foreland basin, which shows analogy to the most ${ }^{13} \mathrm{C}$-enriched Recent marine carbonates (e.g. oolites) observed in the semi-enclosed foreland basin of the Persian Gulf (Gischler et al. 2007).

The maximum $\delta^{13} \mathrm{C}$ values recorded for the mid-Ludfordian excursion in a less restricted part of the same basin reached $\sim 8.5 \%$ in the brachiopod shells from Gotland (Samtleben et al. 2000). The similar maximal absolute values of the mid-Ludfordian CIE are recognized across the carbonate platforms of Baltica, Perunica and Gondwana. In the inner platform areas the CIE maximal values (S-Zone - Frýda \& Manda 2013) are probably missing due to the emersion of the platform top, during the prolonged sea-level lowstand (see discussions in Lehnert 2007, Kozłowski \& Sobień 2012, Gocke et al. 2013, Frýda \& Manda 2013).

The mid-Ludfordian CIE record from the deep-water facies (thus rather complete successions) is insufficiently recognized. The part of the studied sections, such as Oklahoma (Barrick et al. 2010) and the Timan-Pechora Basin (Modzalevskaja \& Wenzel 1999), are sampled in low resolution and contain only few $\delta^{13} \mathrm{C}$ measurements across the CIE interval (showing relatively low CIE amplitude). The thick pile of the outer carbonate platform succession in the Barrandian area shows higher values up to +9\%o (Frýda \& Manda 2013). In the case of the Carnic Alps and Sardinia successions (representing distal continental 


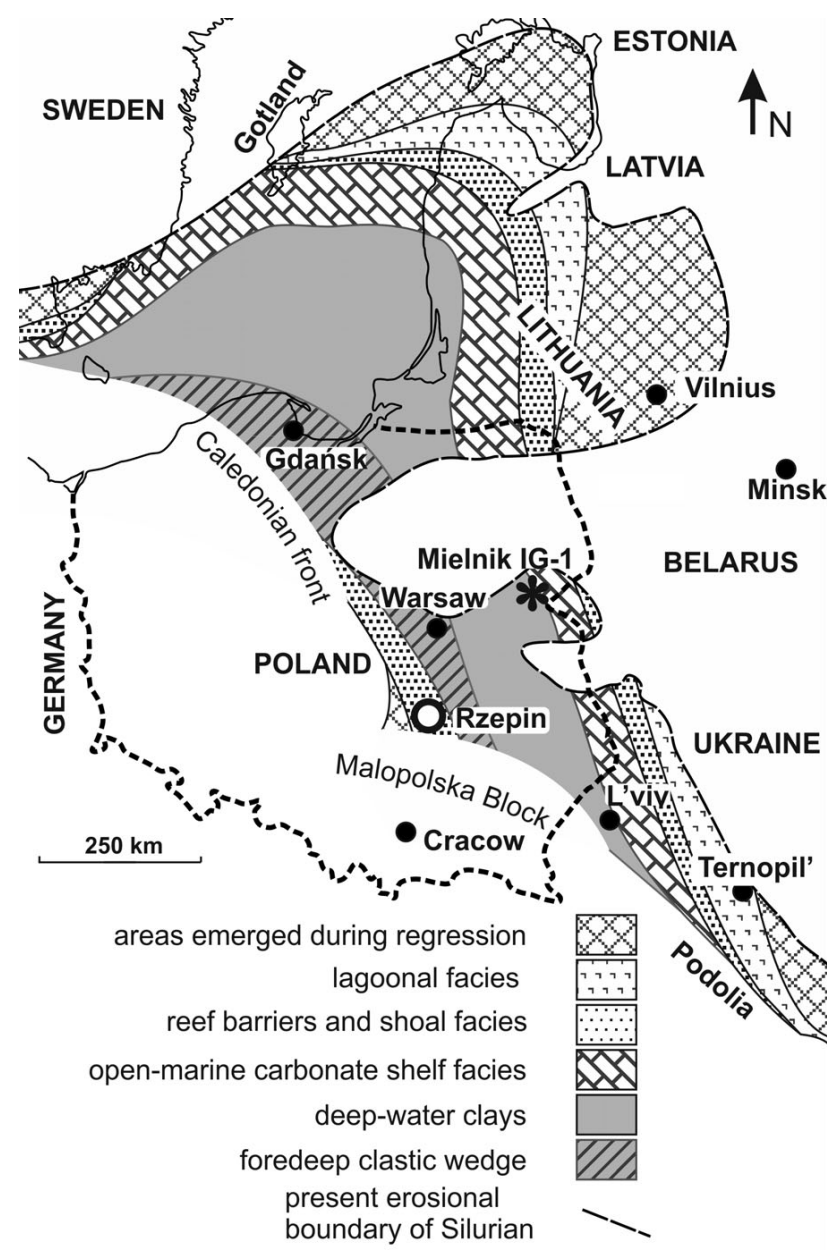

Figure 1. Palaeogeographical map of the Baltic region in the time of the mid-Ludfordian regression (after Kozłowski \& Sobień 2012 and references therein); with location of the Mielnik IG-1 Borehole and the Rzepin section in the Holy Cross Mountains (Kozłowski \& Munnecke 2010).

shelf areas), the lack of the CIE in the Lau Event interval is interpreted as caused by digenetic alternation of the $\delta^{13} \mathrm{C}$ record (Jeppsson et al. 2012). However, the preservation of the distinct positive oxygen isotope excursion in the bulk-rock record of the Ockerkalk succession in Sardinia suggests that the coeval minor negative CIE (-2.61\%oJeppsson et al. 2012) represent not-altered C-isotope oceanic record of the studied event.

\section{Geological setting and outline of the sedimentary environment in the Mielnik IG-1 section}

The upper Silurian rocks of northeastern Poland represent a relatively narrow foreland basin of the Tornquist branch of the Caledonian orogen, located along the southwestern margin of the Baltica sector of the Laurussia palaeocontinent. From the northeast, the basin was bounded by the re- latively slowly subsiding extensive carbonate platform, limited by a low-relief land. The opposite shore represented a partly emerged clastic ramp (Kozłowski 2003) of the arc-continent orogen (Kozłowski et al. 2014), delivering large amounts of clastic material to the rapidly subsiding foredeep.

The Mielnik IG-1 Borehole is situated in easternmost Poland (Fig. 1) within the peri-platform, carbonate-bearing facies zone of the deeper part of the basin. The section is known from three-dimensionally preserved graptolites, providing a high-resolution biostratigraphic subdivision (Urbanek 1970, 1997; summarized in Kozłowski \& Sobień 2012).

The almost fully cored Ludfordian is composed of a relatively uniform complex of calcareous claystones with thin fine-grained, muddy limestone intercalations. According to Kozłowski \& Sobień (2012), the rocks contain abundant graptolites, nautiloids and sparse benthic fauna (limited to a few horizons). The dominant grey colour of the claystones, the well-preserved graptolite fossils and the local high abundance of pyrite suggest low-oxygen conditions in the sedimentary environment. The general lithology, fauna and carbonate microfacies indicate a calm, relatively deep-water, suspension dominated, sedimentary environment of the Mielnik IG-1 succession. The lack of erosive surfaces and a considerable thickness suggest high completeness of the sedimentary record. The relatively high and possibly nearly constant rate of deposition may be estimated (without decompaction) at on average $\sim 1.05 \mathrm{~m}$ per 10 ka (Kozłowski \& Sobień 2012).

According to Kozłowski \& Sobień (2012), the kozlowski/Lau Event interval in the succession is represented by a 9 m thick "dolomite siltstone" bed, which contains the mid-Ludfordian CIE that reaches up to $6.74 \%$ o (Fig. 2). In the sequence stratigraphic framework, which was based on spectral gamma-ray geochemistry, the increasing limb of the CIE begins close to the sequence boundary equivalent, marked by a relative enrichment of thorium. Near the base of the event interval, despite distinct changes in the composition of the rock-forming components, there are no textural signs of bathymetric changes. The event bed shows delicate lamination or a chaotic texture and is composed of very fine carbonate grains, which along with the presence of graptolites and cephalopods indicate the retaining of pelagic, low-energy, open marine conditions with sedimentation dominated by suspension from the water column. A more significant change occurs in the top of the event interval, where bioclastic and peloidal grainstone intercalations within the graptolitebearing claystones suggest dynamic events of carbonate redeposition. Near this level, sparse fossils of trilobites, crinoids and ostracods are noted in the co-occurring marls. These fossils point to the temporal colonization of the sea bottom and record a potential temporary shallowing trend. 
Gradual recurrence to the graptolite-bearing calcareous claystones upsection records transgressive conditions towards a pronounced maximum flooding surface (marked by distinct enrichment of uranium), noted at the depth 816-822 m, in the Monograptus balticus Zone.

\section{Methods}

Microfacies analysis. - The same sample set used in an earlier study (Kozłowski \& Sobień 2012) was used for the purposes of this study. However, a new thin section set was prepared (uncovered, fine polished). One-third of each thin section was stained using the Dickson solution (Dickson 1965). The observations were performed with the maximum magnification of an optical microscope (NikonEclipse LV100POL with 60× Plan Fluor lens and LUCIA software) with parallel examination of thin sections and rock crumbs in an SEM-backscatter with EDS in the SEM and Microanalysis Laboratory of the Faculty of Geology, University of Warsaw.

The semi-quantitative mineral composition of the 45 bulk rock samples across the CIE was determined using XRD analysis (Bragg - Brentanu method) in the XRD Laboratory of the Faculty of Geology, University of Warsaw. 1 -gram portions of the powdered and homogenized disoriented samples were inserted into Al-sample holders and exposed to $\mathrm{CoK} \alpha$ radiation in a X'Pert PRO MPD (PANalytical B.V. - Holland) diffractometer, with d-value calibration to a pressed silicon powder sample $(32 / 2 \mathrm{~mm}$; Panalytical). Diffractograms were measured in the interval between $3.778^{\circ} 2 \theta$, with step $0.026^{\circ} 2 \theta$ and counting time of 3 hours with the use of a PIXcel high-speed line detector (928 s per step) and $40 \mathrm{kV} / 30 \mathrm{~mA}$. Qualitative and semi-quantitative mineral compositions were based on automatching peak identification and relative intensity measurements of the X-Ray patterns (peak area method) using the Normalized Reference Intensity Ratio analysis of the X'Pert HighScore Plus software package (version 2.2). The relative intensities were corrected using correction factors (I/Icor) from the PDF2 database of the International Center for Diffraction Data. The semi-quantitative mineralogy was calculated as mass percentages of the total crystalline fraction, according to the matrix flushing method, with external calibration to a pure $\alpha$-quartz reference standard (NIST - SRM 1878a respirable $\alpha$ ). The analytical reproducibility of the method is below $5 \%$.

Size-frequency distribution of the pyrite spheroids (>100 grains/sample) was measured and counted on the scaled SEM-backscatter images of thin sections. The maximum and average size $[\mu \mathrm{m}]$, along with the normalized grain abundances [grain $/ \mathrm{mm}^{2}$ ] and normalized pyrite content [\%] were calculated based on the collected data.

Separation of the dolomite grains was performed for 20 selected samples across the CIE. $1 \mathrm{~g}$ portions of each sample were mechanically crushed and dry-sieved at mesh size of $1.0 \mathrm{~mm}$. The smaller fraction was placed on a sieve with a $90-\mu \mathrm{m}$ mesh and agitated for 2 minutes in a $10 \%$ acetic acid, diluted with distilled water. After the next 2 minutes, the resulting suspension was filtered through a $60-\mu \mathrm{m}$ sieve. The smaller fraction was collected and left standing for the next 2 minutes in the diluted acid for further leaching and settling. Next, the acid was decanted and the residuum was collected in a 1-litre beaker filled with distilled water. The whole procedure was repeated several times, with recycling of the decanted acid and the larger fractions. At the end of the process, the collected residuum was carefully rinsed with distilled water, decanted and left standing to dry up at room temperature. The quality of the separates was controlled by SEM-EDS and XRD analyses. Half of each dry separate was powdered and homogenized in an agate mortar for the isotope measurements.

Carbon and oxygen isotope values of the dolomite separates were determined in the Stable Isotope Laboratory of the Polish Academy of Sciences in Warsaw. Each sample was treated with phosphoric acid in a Kiel IV preparation system and analysed in a conjunct Finnigan Delta+ mass spectrometer. The values were reported in the conventional delta notation with respect to the Vienna Pee Dee Belemnite (VPDB). Reproducibility for the isotopic analysis was better than $\pm 0.1 \%$. The oxygen isotope ratios of the dolomite were corrected for acid fractionation of dolomite relative to calcite, using the fractionation factors given by Rosenbaum \& Sheppard (1986).

For the calculations of the $\delta^{13} \mathrm{C}$ for the calcite component the modified methodology and mass balance calculations as described by Baudrand et al. (2012) were applied. The $\delta^{13} \mathrm{C}$ of calcite was calculated as follows: $\delta^{13} \mathrm{C}_{\text {calcite }}=$ $\left(\delta^{13} C_{\text {bulk rock }}-\delta^{13} C_{\text {dolomite }} . \mathrm{X}_{\text {dolomite }}\right) / \mathrm{X}_{\text {calcite }}$; where $\mathrm{X}_{\text {calcite }}$ and $\mathrm{X}_{\text {dolomite }}$ are the weight proportions of calcite and dolomite in the bulk rock, determined from XRD data $\left(\mathrm{X}_{\text {calcite }}+\mathrm{X}_{\text {dolomite }}=1\right)$. Aside from the calculated values in the CIE interval, the $\delta^{13} \mathrm{C}_{\text {calcite }}$ values were also estimated for samples with a known calcite/dolomite ratio, but without the indirectly measured $\delta^{13} \mathrm{C}_{\text {dolomite }}$. Average $\delta^{13} \mathrm{C}_{\text {dolomite }}$ values of the adjacent or lowermost/uppermost samples (in section) were used for these estimations.

\section{Results}

\section{Facies anomaly and event-related grains}

The kozlowski/Lau Event facies anomaly in the study section (Fig. 2) contains three unusual lithotypes formed by similar, peculiar, silt-sized carbonate components (see below; Figs 3-7) with different contributions. The common feature of the facies is a chaotic or finely laminated 


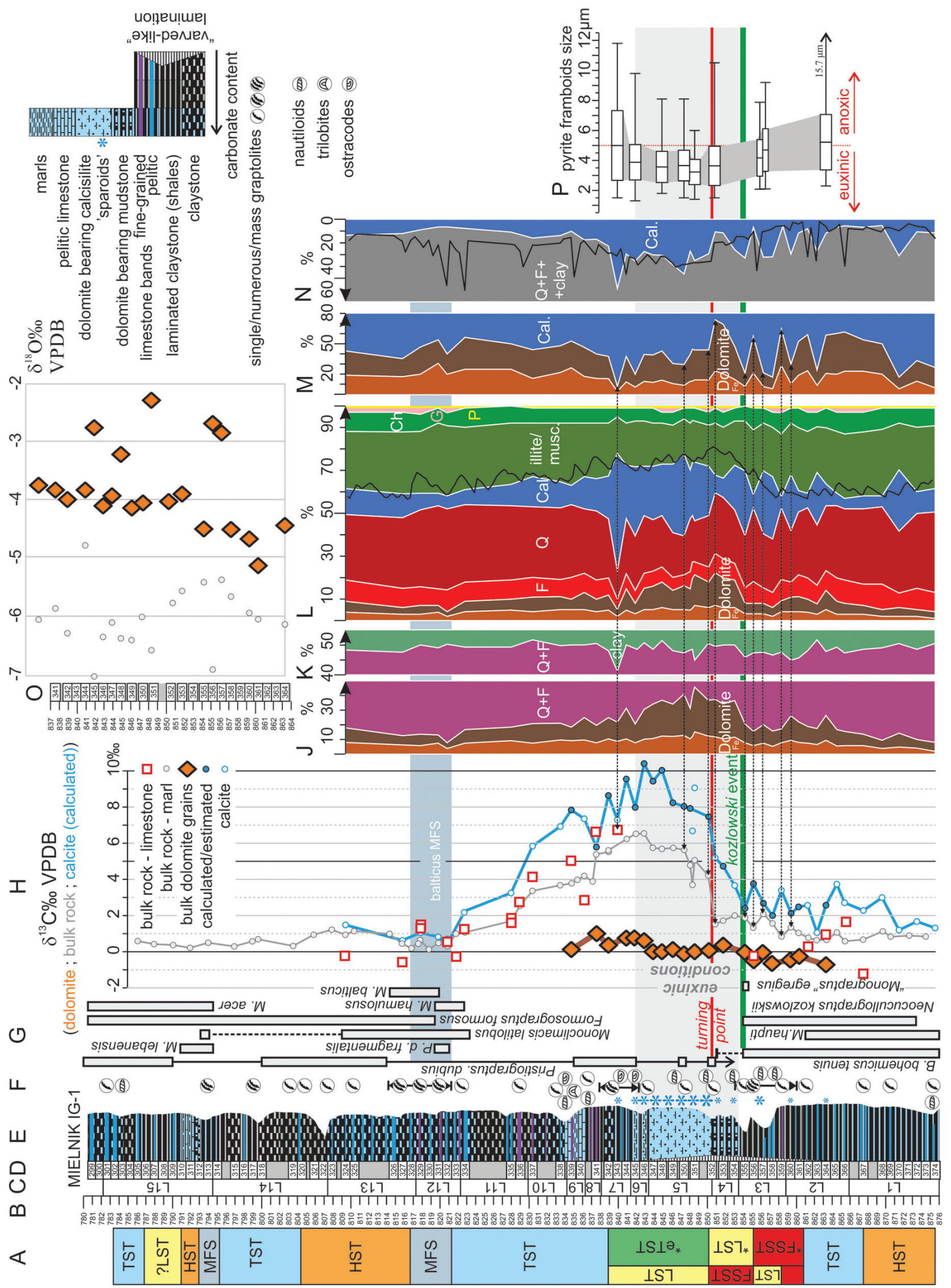


(often with internal gradation) texture, textural inversion of components and lack of erosive surfaces.

Below the CIE interval, from the depth of $866 \mathrm{~m}$ (Fig. 2 - beds L2-L3 in column C), the gradual increase in the contribution of carbonate and clastic silt leads to the appearance of characteristic "varve-like" mudstones. The pronounced facies anomaly starts with a $3 \mathrm{~m}$ thick dolomite-bearing mudstone (L4) occurs immediately above the kozlowskii graptolite extinction level $(853.5 \mathrm{~m})$. The top of the bed $(850.5 \mathrm{~m})$ is a critical point in the facies succession, named here the "turning point". The bed is covered by the $7 \mathrm{~m}$ thick bed of massive dolomite bearing calcisiltite (L5), succeeded by $2 \mathrm{~m}$ of similar, but laminated calcisiltite interbedded with marls (L6). The base of the calcisiltite interval (L5) showing a radical increase of the bulk-rock carbon isotope signatures. The pronounced facies anomaly (L4-L6) shows strongly negative natural-gamma and magnetic susceptibility values and records the increasing limb of the mid-Ludfordian CIE (Kozłowski \& Sobień 2012).

\section{Event related grains: "sparoids" and rafts}

The calcareous silt component in the facies anomaly interval, aside from the abundant dolomite, contains a second type of similar in size, rhomb-shaped grains and their aggregates - after staining appeared to be composed of calcite ("sparoids").

The proposed here term "sparoids" is defined as syngenetic, often idiomorphic minute calcite crystals, formed in the sedimentary environment and occurring in a sedimentary rock as allochems (loose grains or overgrowths). The "sparoids", in contrast to calcite crystal fans, do not overgrow the components deposited earlier (hence: were not formed as the sea-floor cements). The part of the "sparoid" overgrowths could be classified as "precipitated peloids" (Flügel 2004, p. 117), whereas the detrital grains coated by thin "sparoid" cement could be classified as the cortoids or "pelagic ooids".

The individual "sparoids" are euhedral (Fig. 3A), subhedral to spherical (Figs 4A, 5C), sporadically frac- tured or slightly rounded, reaching 10 to $60 \mu \mathrm{m}$ in size. Inside a large part of the "sparoids", staining revealed an internal web-like porosity, composed of single, serially arranged or densely tangled tabular filaments (Fig. 3A), often observed also as thin films on the grain surfaces. Largest fibre-like single filaments (Fig. 3A, F) resemble modern cyanobacteria Spirulina in size and shape. Some of sparoids exhibit relicts of skeletal dolomite rims (Figs 4A, 5B), hence they have been classified as calcitized dedolomite grains. The "sparoid"-like calcite cement occurs also as a thin cortex around dolomite, calcite, quartz and muscovite, forming minute (up to $60 \mu \mathrm{m}$ ) coated grains (Fig. 3C-F). The grain nuclei as well as the cortex surfaces are often covered with tabular filaments (Fig. 3C, F). Part of the "sparoids" surrounds individual grains or groups of grains (Fig. 4A), or is bound by filaments into larger aggregates (Fig. 4B, C). In some cases, serially arranged clusters of up to a dozen or so "sparoids" (Figs 4B, 6A) and other grains (e.g. dolomite) are coupled into "sparoid chains". The chains are chaotically crumpled (Fig. 6A) or doubled-up, enclosing dolomite, quartz and/or muscovite grains within them (Fig. 4B). The interconnected and/or intergrowth "sparoids" form rigid clusters (Figs 3B, 5A-D, $6 \mathrm{~B}, 7 \mathrm{C})$. The radially arranged "sparoids" may form spheroids (up to $80 \mu \mathrm{m}$ in diameter - Fig. 3B), which are sometimes incorporated into larger aggregates (Fig. 5C). The larger calcite flakes, up to $2 \mathrm{~cm}$ long and $0.1 \mathrm{~mm}$ thick, show a mosaic (Fig. 5A) to dendritic, lace-like texture with occasionally preserved details of the crystal growth patterns (Fig. 7B). Some of the flakes show an asymmetric organization, with one surface relatively smooth and flat, contrasting with the distinctly rough opposite side (Figs 4D, 6B, 7A, C). The flat surface locally shows cement outgrowths and adhered individual detrital grains (Figs 4D, 7A). The near-surface layer (20 to $40 \mu \mathrm{m}$ thick) of a flake is exclusively composed of "sparoid" cement (Fig. 7A) separating the flat surface from the zone with incorporated grains (dolomite, quartz, mica), which are additionally bound by microbial filaments (Fig. 4D). Smaller flakes often have both sides with identical surfaces, flat or dentate (Figs 5A, 6B). The thickest calcite flakes are formed

Figure 2. Lithological, geochemical and mineralogical logs of the Mielnik IG-1 section and its sequence stratigraphic interpretation (A-F: after Kozłowski \& Sobień 2012). • A - sequence stratigraphic interpretation (*partly changed) based on the spectral natural gamma-ray geochemistry and facies record; B - depth in metres; C - lithological complexes; D - core samples (archival boxes); E - lithological log; F - macrofossil occurrences; G - graptolite ranges (after Urbanek 1970, 1997); H - bulk rock (after Kozłowski \& Sobień 2012), dolomite (this study) and calculated/estimated calcite (this study) carbon isotope data; J - vertical changes in the contribution of dolomite in the terrigenous silt (dolomite/QF ratio) interpreted as representing relative eolian dust contribution; $\mathrm{K}$ - vertical changes in the $\mathrm{Q}+\mathrm{F} /$ clay ratio showing its relative consistence across the event; $\mathrm{L}-$ vertical changes in the total mineralogical composition of the bulk rock (Fe - iron-rich dolomite, F- feldspar, Q - quartz, Cal. - calcite, musc. - muscovite, Ch - chlorite, $\mathrm{P}$ - pyrite, $\mathrm{G}$ - gypsum); note that the total natural gamma log (mirrored, black solid line) depends on the clay mineral content which is suppressed by admixture of dolomite and calcite; $\mathrm{M}$ - vertical changes in the carbonate composition; note the distinct dependence of the bulk rock $\delta^{13} \mathrm{C}$ values on the dolomite/calcite ratio (horizontal arrows); $\mathrm{N}$ - vertical changes of the QFClay/calcite ratio; note pattern similarity with (M); solid line represents magnetic susceptibility (after Kozłowski \& Sobień 2012) and seems to mirror the contribution of calcite precipitates; O - dolomite vs. bulk rock logs of the oxygen isotope data; P - box-and-whisker plots of pyrite framboid sizes; the grey background marks the interpreted euxinic part of the succession. 
along an axial surface composed of tabular filaments. The filaments, occurring also inside the domes, are arranged in a stromatolitic convex-upward lamination (Fig. 5D). The stromatolitic domes often occur on both sides of the flake (Fig. 5C, D), forming a flat oncoid-like grain.

Interpretation. - Chaotic texture, unsorted components and textural inversion indicate deposition by a relatively continuous settling from a suspension. "Sparoids" in their general features and size are very similar to the bacterially induced water-column carbonate precipitates observed in laboratory experiments and the recent natural environment (hard water lakes and rivers). Such precipitates are a few, to tens of $\mu \mathrm{m}$ in diameter and consist of single euhedral calcite rhombohedra, crystal overgrowths and spheroids (Braissant et al. 2003, Chekroun et al. 2004, Bosak \& Newman 2005). The tabular filaments inside the "sparoids" are interpreted as entombed picoplankton cells (Bradley 1963). In the case of recent grains, the picocyanobacterial cells, which serve as nucleation sites and induce calcite precipitation, are often incorporated into the crystal interior and preserved as imprints or holes (Bradley 1963, Thompson \& Ferris 1990, Dittrich et al. 2004, Dittrich \& Obst 2004, Li et al. 2011). In the case of longer calcification of the suspended cyanobacterial film, the intergrown crystals may form spheroids and aggregates (Brehm et al. 2004), similar to the observed clusters. The "sparoid chains" are interpreted as sections of agglomeration of single crystals on a flexible microbial film that was crumpled during sinking (Fig. 8). The doubled-up "chains" with detrital material enclosed inside (Fig. 4B) are interpreted as ballasted marine snow aggregates (Fig. 8). The extensive, flat, internally geopetal "sparoid" clusters - with one planar face and the opposite side coated with detrital particles - are interpreted as marine analogues of recent calcite rafts. The rafts are extremely thin calcite crusts drifting at the water-air interface that stay afloat by surface tension or gas bubbles (Onac 1997). Recently, they are known exclusively from the surfaces of water pools in caves (Jones 1989) and hardwater river systems (Taylor et al. 2004). Recent rafts comprise inter-growing clusters of calcite rhombohedra, up to $30 \mu \mathrm{m}$ in size. The aggregates grow downward into the water column, up to the thickness of several hundred of microns and dozen-or-so centimetres in diameter and form an extensive film covering the pool surface. Recent calcite rafts, contain incorporated eolian grains and picocyanobacterial cells (Taylor et al. 2004). The sinking rafts may develop into a coarse, often laminated carbonate sediment (For- nós et al. 2009), which may contain a significant admixture of calcite crystals that precipitated in the water column by bacterial activity (Taylor et al. 2004).

The calcite flakes with two- or multi-side growth directions, as well as the minute coated grains are interpreted as growing in suspension in the photic zone of the water column (Fig. 8), which is indicated by entombed microbial filaments. The observed incorporation of smaller crystal clusters inside the larger ones suggests a long residence time of grains in the near-surface layer. The calcite aggregates with a multisided growth are regarded as an analogue of the grain components of the recent calcareous floating mat of Everglades periphyton (Donar et al. 2004).

It is worth to notice that the proposed recent analogues of "sparoids" represent non-marine environments, whereas studied here sedimentary rocks were deposited in the open marine setting. However, recent marine water-column precipitates are preferentially aragonitic, whereas Silurian seas were calcite dominated (Sandberg 1983). Hence, the recent fresh-water carbonate bearing polls with calcite precipitation seem to be closer analogues for the Silurian carbonate factory.

\section{Event related grains: dolomite and siliciclastic material}

Dolomite occurs as independent, euhedral crystals with clear rims, and as angular, sub-rounded or well-rounded grains (Figs 4E, 6C). Most of the dolomite grains are 20 to $40 \mu \mathrm{m}$ in size with a maximal diameter reaching $50 \mu \mathrm{m}$. The grain sizes vary in the succession, but are consistent horizontally (Fig. 6D). In the backscattered images some grains show a zoning composition. In these cases, the dull irregular nuclei, composed of near-stoichiometric dolomite based on EDS analysis, are overgrown by thin, bright syntaxial rims of ferroan dolomite, which cement the grains into a rhombohedral slice (Fig. 6E). Both phases are distinguishable also in the XRD analysis as Fe-poor and Fe-rich (near ankerite) dolomite composition.

Homogenous euhedral crystals (without syntaxial rims) contain porous grains often with minute $(<1 \mu \mathrm{m})$ pyrite inclusions (Fig. 6A, D, E). Another group of relatively large, well-developed rhombs (also without syntaxial rims) has hollows infilled with calcite-entombed microbial filaments (Figs 5B, 6E). The skeletal dolomite rims on the internal walls show signs of corrosion and sometimes exhibit signs of fracturing and deformation.

Figure 3. Micrographs of stained thin-sections from the Mielnik IG-1 core, showing details of "sparoid" grains. • A - internal anatomy of "sparoids" showing the mass occurrence of Spirulina-like picocyanobacterial filaments (arrowed; see also red arrow on F). • B - large radially arranged spheroid cluster of "sparoids". • C-F - "sparoids" overgrowing euhedral (C, D), twinned (C) and abraded-rounded (E) dolomite crystals as well as quartz grain (F); note omnipresence of microbial films and filaments occurring both on the surface of incorporated grains and on/between the "sparoids" (arrows); A-F - sample/box 351. 

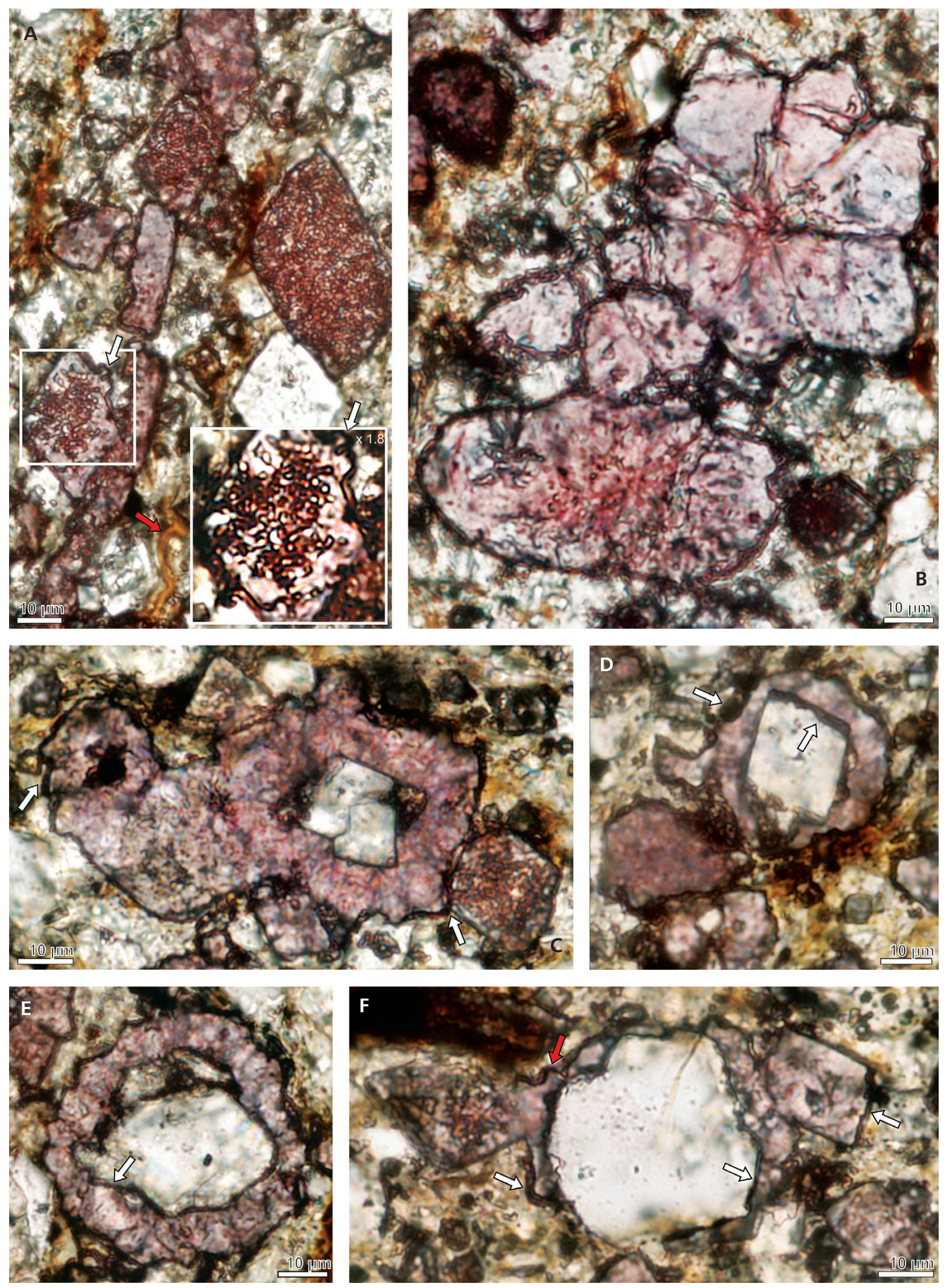
The dolomite grains occur as loose grains or, along with quartz and mica (or mica only), as very thin (up to $0.2 \mathrm{~mm}$ ) laminae without an evident erosive basal surface. Dolomite and quartz show a common grain-size distribution with distinctly common vertical changes (Fig. 6D). The dolomite, quartz and mica are commonly incorporated in the single "sparoids" and their aggregates (Figs 3C-F, 6B, E, 7B). The grains occur also as components of rafts or are sandwiched in the doubled-up "sparoid chains". The grains incorporated into the calcite aggregates are randomly dispersed without evident sorting. In some cases the dolomite grains incorporated into the flakes are truncated by the surfaces of the aggregate (Fig. 5A).

Substantial part of the detrital laminae, named here as "double-acting laminae", demonstrates internal density gradation of grains in form of the dolomite-quartz couplets (Figs 6D, 7A). The "double-acting laminae" are very thin, without the erosive surface at the base. Their lower part is composed of fining-upward dolomite grains. The upper part is dominated by quartz grains, which in substantial part are larger than the dolomite. Some of the dolomite grains in the lamina base are cemented together (by calcite) into small aggregates. Calcite rafts or "sparoid" clusters are often present close to laminae top.

The carbon isotope ratios of dolomite $\left(\delta^{13} \mathrm{C}_{\text {dolomite }}\right)$ show a relatively narrow range of values from 0.72 to 1.01 (Table 1). The $\delta^{13} \mathrm{C}_{\text {dolomite }}$ values are nearly constant across the CIE (dolomite does not record the CIE (!) - Fig. 2H). However, in a few minor trends, the $\delta^{13} \mathrm{C}_{\text {dolomite }}$ oscillations locally seem to slightly follow the $\delta^{13} \mathrm{C}_{\text {bulk-rock }}$ oscillations (e.g. boxes/samples 358-355, 348-344). The oxygen isotope ratios of the dolomite grains both in values and trends in the succession do not show correlation with the respective bulk-rock samples (Fig. 2O, Table 1).

Interpretation. - The common sorting between dolomite and quartz, along with the distinct signs of abrasion and incorporation of dolomite grains into composite grains, indicate a detrital origin of the dolomite. Some of the grains (with syntaxial overgrowths) contain a surface layer of the diagenetic, secondary ferroan dolomite formed around the Fe-poor detrital nuclei (see Martire et al. 2014).

Despite this minor contamination, the dolomite does not record the CIE, which is pronounced and omnipresent in the whole basin. The extrabasinal formation of the detrital dolomite grains is confirmed also by the decoupling of dolomite and bulk-rock oxygen isotope record. The detrital dolomite is interpreted as delivered from various sources localized on the carbonate platform top emerged during sea-level fall. The very consistent $\delta^{13} \mathrm{C}$ signatures of the dolomite are presumably caused by lateral averaging of the detritus, similar diagenetic changes, as well as auto-buffering of the carbon isotope system in the source area. Local minor scale fluctuations of the $\delta^{13} \mathrm{C}_{\text {dolomite, }}$, corresponding to the $\delta^{13} \mathrm{C}_{\text {bulk rock }}$ variations, are probably caused by contamination with the diagenetic syntaxial rims of ferroan dolomite, which are expected to be isotopically consistent with the host-rock. Some contamination of the dolomite separates by calcite, especially infilling holes in dedolomite crystals, is an additional possible explanation.

The presence of different types of grains in the dolomite suite suggests its derivation from an inconsistent source. Some of the grains show earlier dedolomitization, which preceded the infilling of hollows by a syngenetic "sparoid" cement that had entombed the microbial filaments. The dedolomite is interpreted as being derived from a pedogenic-karstic environment, whereas the well-preserved, porous, euhedral dolomite crystals, containing minute pyrite inclusions, presumably originate from a sabkha setting. The carbon and oxygen isotope signatures, as well as the spectrum of grain types well fitting to the mixture of dolomite derived from the coastal plain environments with evaporitic and karstic-pedogenic settings of dolomite formation (see Kearsey et al. 2012, Naiman et al. 2000, Warren 2000).

The well-separated, density-differing mineral components (dolomite, quartz) within one, very thin, "double-acting" lamina, suggest a long-term settling of simultaneously delivered small amounts of dolomite-quartz silt in a very calm environment (Fig. 8). The density separation of the settled components should be favored in the case of particles drowning from one level (water surface), contrary to laminae formed by grains settling from a relatively thick suspension plume. An earlier settling of the dolomite grains with a higher density $\left(2.85 \mathrm{~g} / \mathrm{cm}^{3}\right.$ vs $\left.2.65 \mathrm{~g} / \mathrm{cm}^{3}\right)$ would also be favoured by the faster overcoming of the water surface tension by the denser grains in the case of the dry deposition of airborne material (Fig. 8). The preferential

Figure 4. Micrographs of stained thin-sections of the dolomite-bearing calcisiltites from the Mielnik IG-1 core. • A - "sparoid" clusters surrounding single dolomite grains (white arrows), red arrows indicate "sparoids" with dolomite rims interpreted as calcitized dedolomite. $\bullet$ B - doubled-up fragment of "sparoid chain" with detrital material enclosed inside, bound by thin microbial filaments (arrowed); the grain is interpreted as a ballasted aggregate. - $\mathrm{C}$ - amorphous calcite aggregate containing dolomite, quartz and mica; note large flattened quartz grain inside. $\bullet$ D - fragment of calcite raft with adhered grains on top (arrowed) and ingrown dolomite and "sparoid" grains on the underside; note grains bound by microbial filaments (A-D - box/sample 351). E - interior of a calcite cemented aggregate containing abundant dolomite, muscovite and quartz grains; note various rate of abrasion (euhedral, angular to rounded) of the dolomite grains (arrowed); sample 364. $\bullet \mathrm{F}, \mathrm{G}-$ loricas of tintinids ("calpionellids") evidencing calcification event across the "turning point" ( $\mathrm{F}$ - box/sample 352, beneath the "turning point"; $\mathrm{G}$ - box sample 351, above the "turning point"). 

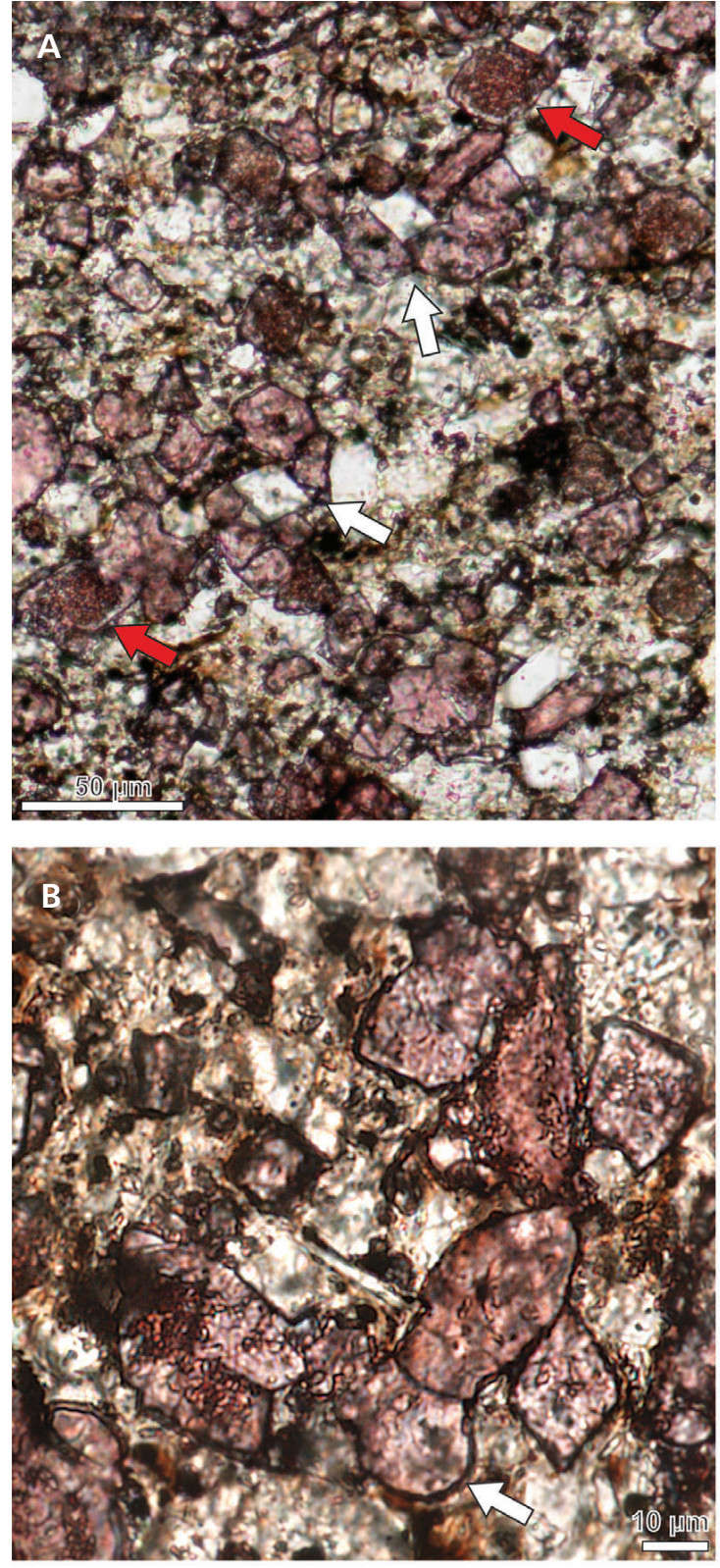
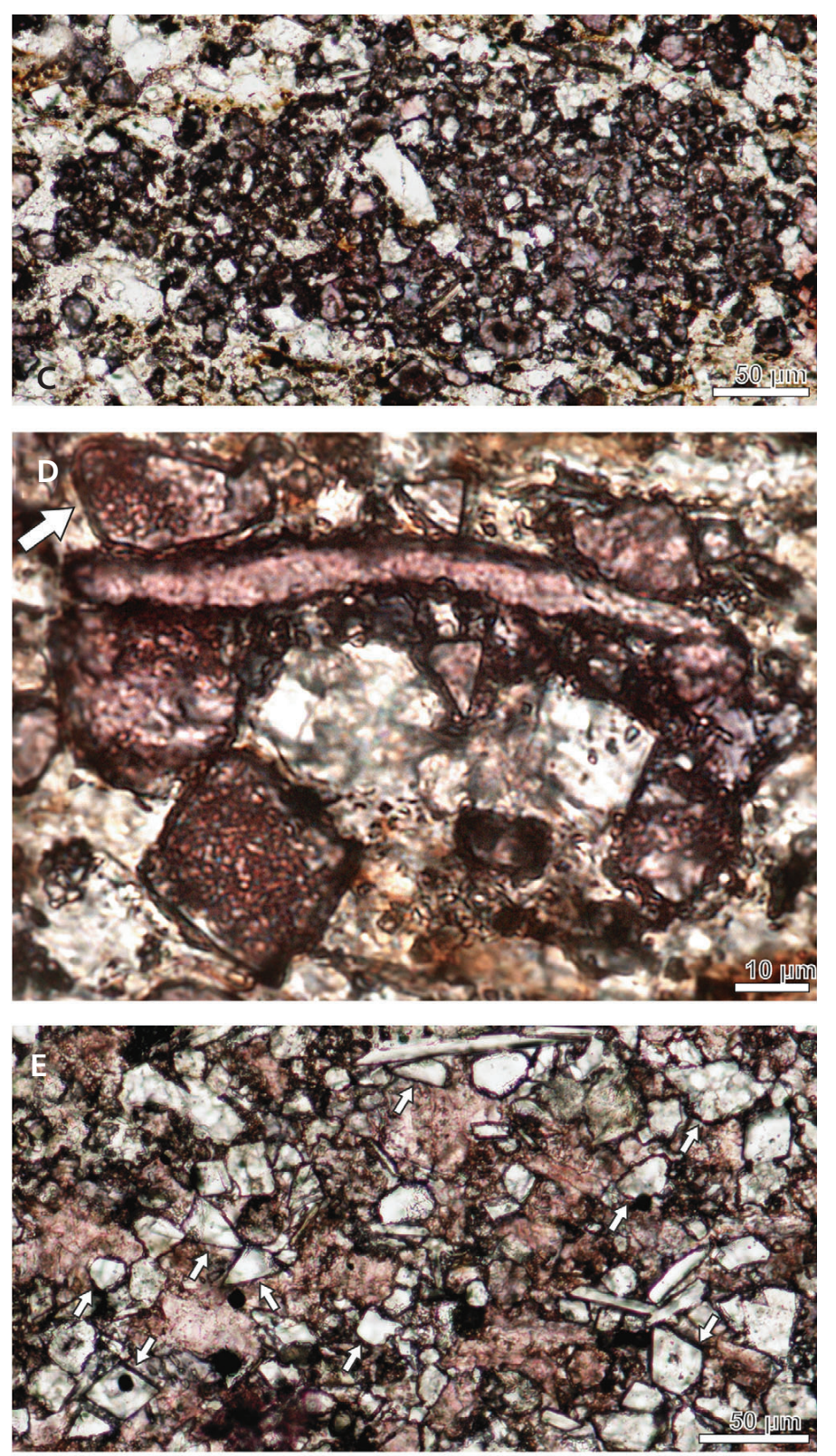
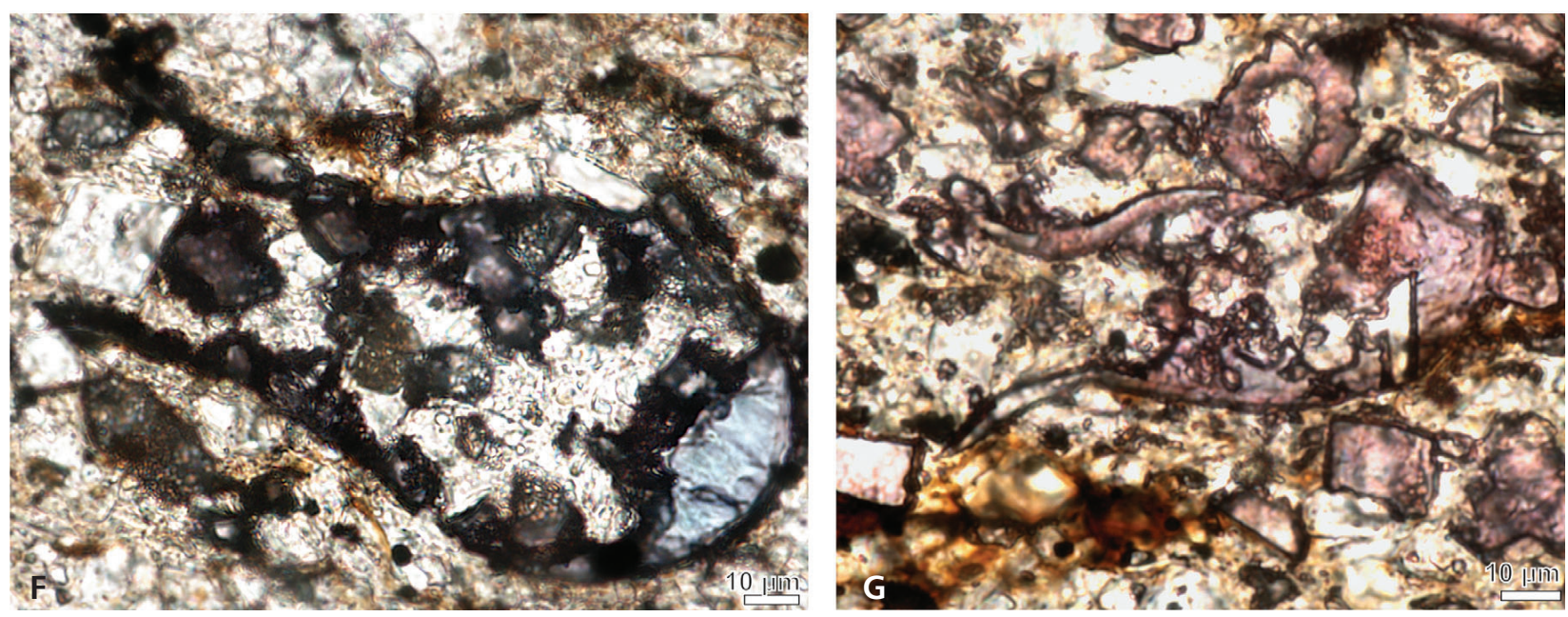
Table 1. Measured bulk rock (after Kozłowski \& Sobień 2012), measured dolomite, calculated/estimated calcite carbon and oxygen isotope signatures for samples from the Mielnik IG-1 section; and bulk rock mineral composition obtained from semi-quantitative XRD analysis. * The oxygen isotope recalculated** according to \% of the dolomite in the carbonates (after XRD). ** The oxygen isotope ratios for dolomite were calculated after Rosenbaum \& Sheppard (1986).

\begin{tabular}{|c|c|c|c|c|c|c|c|c|c|c|c|c|c|c|c|c|c|c|c|}
\hline \multirow[b]{2}{*}{ 营 } & \multirow[b]{2}{*}{ 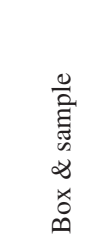 } & \multicolumn{3}{|c|}{ Bulk-rock } & \multicolumn{3}{|c|}{ Dolomite } & \multicolumn{12}{|c|}{ Bulk composition (semi-quantitative XRD) } \\
\hline & & $\sum_{\substack{\infty \\
\infty}}^{\infty}$ & $\begin{array}{l}\stackrel{n}{0} \\
\sum_{0}^{\infty} \\
0 \\
\infty\end{array}$ & 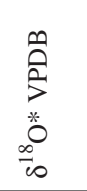 & $\sum_{\substack{\infty \\
0}}^{\infty}$ & 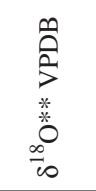 & 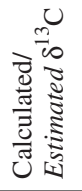 & $\stackrel{\stackrel{N}{*}}{\stackrel{\Xi}{*}}$ & 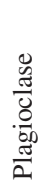 & $\begin{array}{l}\stackrel{\mathscr{\Xi}}{\Xi} \\
\stackrel{0}{\circ} \\
\stackrel{0}{\circ}\end{array}$ & 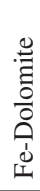 & $\frac{\stackrel{0}{0}}{\frac{0}{\pi}}$ & $\stackrel{\cong}{.}$ & $\frac{\stackrel{\mathscr{D}}{0}}{\frac{0}{U}}$ & 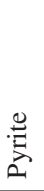 & 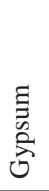 & $\frac{\text { }}{\stackrel{\pi}{0}}$ & $\overrightarrow{\stackrel{\circ}{\circ}}$ & 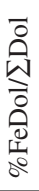 \\
\hline 809.4 & 324_i & 0.90 & -6.12 & -6.82 & & & 1.49 & 31 & 10 & 5 & 4 & 12 & 27 & 9 & 1 & 2 & 0.75 & 9 & 44 \\
\hline 815.8 & 327_i & 0.44 & -6.69 & -7.26 & & & 0.61 & 33 & 9 & 3 & 3 & 11 & 29 & 9 & 1 & 2 & 0.55 & 6 & 50 \\
\hline 817.8 & 329_m & 0.62 & -6.67 & -7.43 & & & 1.05 & 36 & 9 & 4 & 3 & 8 & 29 & 8 & 1 & 3 & 0.88 & 7 & 43 \\
\hline 819.8 & 331_1 & 0.44 & -6.04 & -6.92 & & & 0.82 & 39 & 8 & 3 & 4 & 6 & 33 & 7 & 1 & 0 & 1.17 & 7 & 57 \\
\hline 820.8 & 332_i & 0.31 & -6.92 & -7.57 & & & 0.44 & 37 & 10 & 2 & 2 & 6 & 32 & 6 & 1 & 2 & 0.67 & 4 & 50 \\
\hline 822.8 & 334_i & 1.06 & -4.97 & -5.88 & & & 2.26 & 36 & 9 & 5 & 4 & 7 & 29 & 9 & 1 & 0 & 1.29 & 9 & 44 \\
\hline 828 & 335_i & 1.68 & -5.54 & -6.35 & & & 3.24 & 35 & 9 & 5 & 5 & 10 & 29 & 8 & 0 & 0 & 1.00 & 10 & 50 \\
\hline 830.4 & 337_i & 3.33 & -5.79 & -6.50 & & & 5.85 & 33 & 9 & 7 & 4 & 14 & 25 & 7 & 1 & 0 & 0.79 & 11 & 36 \\
\hline 833.5 & 338_i & 3.68 & -5.53 & -6.31 & & & 6.94 & 33 & 8 & 6 & 5 & 12 & 27 & 7 & 1 & 0 & 0.92 & 11 & 45 \\
\hline 834.7 & 339_i & 3.78 & -5.19 & -6.05 & 0.12 & -3.75 & 7.84 & 34 & 10 & 5 & 5 & 9 & 29 & 7 & 1 & 0 & 1.11 & 10 & 50 \\
\hline 836.2 & 340_d & 4.21 & -5.45 & -6.20 & & & 7.36 & 30 & 9 & 8 & 5 & 15 & 25 & 7 & 1 & 0 & 0.87 & 13 & 38 \\
\hline 837.1 & 341_m & 3.87 & -5.21 & -5.86 & 1.01 & -3.83 & 5.78 & 32 & 9 & 6 & 4 & 15 & 26 & 7 & 1 & 0 & 0.67 & 10 & 40 \\
\hline 838.9 & 342_m & 5.53 & -5.65 & -6.27 & 0.36 & -3.98 & 8.64 & 28 & 8 & 7 & 5 & 20 & 25 & 7 & 1 & 0 & 0.60 & 12 & 42 \\
\hline 839.9 & 343 & 6.74 & -4.85 & -4.98 & & & 7.30 & 13 & 5 & 3 & 2 & 55 & 17 & 4 & 1 & 0 & 0.09 & 5 & 40 \\
\hline 840.9 & 344 & 6.24 & -4.16 & -4.78 & 0.75 & -3.83 & 9.54 & 26 & 7 & 10 & 5 & 25 & 20 & 7 & 1 & 0 & 0.60 & 15 & 33 \\
\hline 841.9 & 345 & 6.53 & -6.70 & -7.02 & 0.76 & -2.76 & 7.97 & 25 & 6 & 5 & 3 & 32 & 21 & 6 & 1 & 0 & 0.25 & 8 & 38 \\
\hline 842.9 & 346 & 6.55 & -5.71 & -6.34 & 0.61 & -4.11 & 10.42 & 27 & 7 & 10 & 5 & 23 & 21 & 6 & 1 & 0 & 0.65 & 15 & 33 \\
\hline 843.9 & 347 & 5.75 & -5.47 & -6.10 & 0.01 & -3.93 & 9.42 & 24 & 7 & 11 & 5 & 25 & 20 & 7 & 1 & 0 & 0.64 & 16 & 31 \\
\hline 844.9 & 348 & 5.71 & -5.67 & -6.37 & -0.06 & -3.22 & 10.03 & 24 & 7 & 12 & 6 & 24 & 19 & 5 & 1 & 2 & 0.75 & 18 & 33 \\
\hline 846.1 & 349 & 5.76 & -5.91 & -6.40 & 0.12 & -4.15 & 8.23 & 21 & 6 & 9 & 5 & 32 & 18 & 6 & 1 & 2 & 0.44 & 14 & 36 \\
\hline 847.3 & 350 & 5.63 & -5.52 & -6.01 & -0.12 & -4.05 & 8.04 & 18 & 5 & 11 & 5 & 38 & 16 & 5 & 1 & 0 & 0.42 & 16 & 31 \\
\hline 848.5 & 351_u & 4.80 & -5.94 & -6.57 & -0.02 & -2.29 & 7.94 & 25 & 8 & 10 & 5 & 23 & 22 & 7 & 1 & 0 & 0.65 & 15 & 33 \\
\hline 848.1 & 351_A & 3.70 & -5.45 & -6.16 & & & 6.68 & 22 & 8 & 14 & 6 & 25 & 20 & 6 & 1 & 0 & 0.80 & 20 & 30 \\
\hline 848.1 & 351_m & 5.09 & -5.94 & -6.65 & & & 9.06 & 19 & 6 & 14 & 7 & 27 & 19 & 6 & 1 & 0 & 0.78 & 21 & 33 \\
\hline 850.1 & 352_u & 4.22 & -5.61 & -6.32 & 0.05 & -4.03 & 7.48 & 24 & 7 & 12 & 6 & 23 & 19 & 6 & 1 & 2 & 0.78 & 18 & 33 \\
\hline 850.5 & 352_m & 1.53 & -4.58 & -5.77 & & & 5.19 & 28 & 9 & 15 & 7 & 8 & 24 & 7 & 1 & 0 & 2.75 & 22 & 32 \\
\hline 851.8 & 353 & 1.72 & -4.44 & -5.56 & 0.36 & -3.90 & 4.74 & 29 & 9 & 14 & 6 & 9 & 24 & 7 & 1 & 2 & 2.22 & 20 & 30 \\
\hline 853 & 354 & 2.00 & -5.11 & -5.89 & & & 3.66 & 25 & 8 & 13 & 6 & 21 & 21 & 6 & 1 & 0 & 0.90 & 19 & 32 \\
\hline 854.2 & 355 & 1.87 & -5.07 & -5.41 & -0.03 & -4.50 & 2.38 & 24 & 7 & 5 & 3 & 30 & 23 & 7 & 0 & 0 & 0.27 & 8 & 38 \\
\hline 855.2 & 356_u & 1.32 & -5.98 & -6.90 & -0.50 & -2.69 & 3.75 & 34 & 10 & 5 & 3 & 6 & 30 & 10 & 1 & 0 & 1.33 & 8 & 38 \\
\hline 856.2 & 357 & 2.09 & -5.01 & -5.37 & -0.08 & -2.85 & 2.69 & 25 & 7 & 5 & 3 & 29 & 22 & 7 & 1 & 0 & 0.28 & 8 & 38 \\
\hline 857.3 & 358 & 1.56 & -5.38 & -5.66 & -0.65 & -4.51 & 2.02 & 25 & 7 & 4 & 2 & 29 & 23 & 7 & 1 & 2 & 0.21 & 6 & 33 \\
\hline 858.3 & 359_m & 0.86 & -6.03 & -7.07 & & & 3.40 & 33 & 10 & 5 & 4 & 5 & 29 & 10 & 1 & 2 & 1.80 & 9 & 44 \\
\hline 859.3 & 360_m & 1.35 & -5.45 & -5.94 & -0.46 & -4.67 & 2.12 & 24 & 7 & 7 & 4 & 26 & 24 & 7 & 1 & 0 & 0.42 & 11 & 36 \\
\hline 860.3 & 361_m & 1.04 & -5.20 & -6.04 & -0.26 & -5.13 & 2.48 & 29 & 10 & 7 & 4 & 10 & 29 & 9 & 1 & 0 & 1.10 & 11 & 36 \\
\hline 861.3 & 362_m & 0.82 & -5.55 & -6.51 & & & 2.57 & 33 & 10 & 6 & 4 & 7 & 29 & 9 & 1 & 2 & 1.43 & 10 & 40 \\
\hline 862.3 & 363_m & 0.66 & -5.44 & -5.83 & & & 1.06 & 29 & 9 & 5 & 3 & 25 & 22 & 7 & 1 & 2 & 0.32 & 8 & 38 \\
\hline 863.3 & 364_m & 0.98 & -5.19 & -6.13 & -0.72 & -4.44 & 2.57 & 30 & 9 & 9 & 5 & 10 & 26 & 9 & 1 & 0 & 1.40 & 14 & 36 \\
\hline 864.5 & 365_A & 1.06 & -5.31 & -6.28 & & & 3.73 & 34 & 11 & 6 & 3 & 6 & 29 & 9 & 1 & 2 & 1.50 & 9 & 33 \\
\hline
\end{tabular}




\begin{tabular}{|c|c|c|c|c|c|c|c|c|c|c|c|c|c|c|c|c|c|c|c|}
\hline \multirow[b]{2}{*}{$\begin{array}{l}\text { 苂 } \\
\text { ص̆ }\end{array}$} & \multirow[b]{2}{*}{ 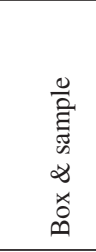 } & \multicolumn{3}{|c|}{ Bulk-rock } & \multicolumn{3}{|c|}{ Dolomite } & \multicolumn{12}{|c|}{ Bulk composition (semi-quantitative XRD) } \\
\hline & & 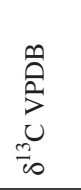 & $\begin{array}{l}\stackrel{\infty}{0} \\
\stackrel{0}{>} \\
\frac{\infty}{\infty}\end{array}$ & 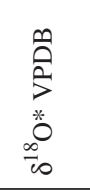 & $\underset{\substack{\infty \\
\stackrel{0}{0}}}{\stackrel{m}{\rho}}$ & 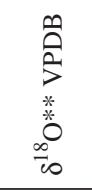 & 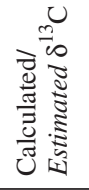 & 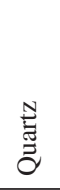 & $\begin{array}{l}0 \\
\frac{0}{0} \\
\frac{0}{0} \\
.00 \\
\frac{\pi}{2} \\
\end{array}$ & 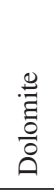 & 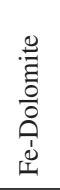 & $\frac{\stackrel{0}{0}}{\frac{0}{\pi}}$ & $\stackrel{气}{.}$ & $\frac{\mathscr{0}}{\frac{0}{\tilde{U}}}$ & 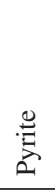 & 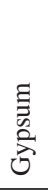 & $\begin{array}{l}\stackrel{\widetilde{\Xi}}{0} \\
\stackrel{\circ}{0}\end{array}$ & 市 & $\begin{array}{l}\bar{\circ} \\
\text { W } \\
\bar{\circ} \\
0 \\
\frac{1}{0} \\
0^{\circ}\end{array}$ \\
\hline 865.5 & 366_m & 0.60 & -5.61 & -6.62 & & & 2.71 & 33 & 11 & 5 & 3 & 5 & 30 & 10 & 1 & 2 & 1.60 & 8 & 38 \\
\hline 867.5 & 367_m & 0.67 & -5.75 & -6.63 & & & 2.29 & 35 & 10 & 4 & 3 & 6 & 30 & 9 & 1 & 2 & 1.17 & 7 & 43 \\
\hline 869.6 & 368 & 1.13 & -4.06 & -4.87 & & & 2.99 & 36 & 12 & 3 & 2 & 5 & 31 & 10 & 1 & 0 & 1.00 & 5 & 40 \\
\hline 871.6 & 370 & & & & & & 1.19 & 29 & 7 & 4 & 2 & 29 & 22 & 7 & 1 & 0 & 0.21 & 6 & 33 \\
\hline 872.6 & 371 & 0.90 & -5.57 & & & & & & & & & & & & & & & & \\
\hline 873.6 & 372 & & & & & & 1.67 & 35 & 10 & 3 & 2 & 10 & 30 & 9 & 1 & 0 & 0.50 & 5 & 40 \\
\hline 874.6 & 373 & 0.84 & -5.53 & & & & & & & & & & & & & & & & \\
\hline 875.6 & 374 & & & & & & 1.31 & 37 & 9 & 3 & 1 & 11 & 29 & 8 & 1 & 0 & 0.36 & 4 & 25 \\
\hline 878.2 & 375 & 0.70 & -3.82 & & & & & & & & & & & & & & & & \\
\hline
\end{tabular}

crystallization of the calcite cement around carbonate particles also could have ballasted the dolomite grains and caused their faster settling.

\section{Event related grains: pyrite}

In all studied samples, the majority of pyrite grains occur as framboids, developed exclusively as spherical aggregates, composed of sub-micron-sized microcrystals. Usually, the framboids are randomly dispersed, with concentrations only on very rare omission surfaces. In the case of the interlayering of detrital (dolomite-quartz) and calcite/"sparoid"-rich laminae, the pyrite spheroids are about two times less abundant in the calcite-dominated horizons (Figs 2P, 9B, C, Table 2). A similar relationship is observed between the dolomite-rich mudstone and calcisiltites enriched in "sparoids" (Figs 2P, 9D, E).

Within the pyrite-bearing interval, coeval with the dolomite-bearing complex (Fig. 2P), the size analysis of the framboids (Table 2, Figs 2P, 9) revealed the distinct domination of tiny (3.23 to $3.88 \mu \mathrm{m}$ in average diameter), spheroidal grains strongly consistent in size (standard derivation of 0.84 to $1.31 \mu \mathrm{m}$ ), characterized by low skewness (all samples below 2.0). Aggregates larger than $10 \mu \mathrm{m}$ are extremely rare. The pyrite framboids occur outside the "sparoids" and their clusters (Figs 6, 7). Rare pyrite grains noted inside the "sparoid" aggregates are distinctly smaller ( $<1 \mu \mathrm{m}$; Fig. 7A) and occur preferentially near the cluster margin (Fig. 7B). Exceptionally, single anhedral, porous calcite grains contain abundant minute-sized $(<1 \mu \mathrm{m}) \mathrm{cu}-$ bic pyrite crystals (Fig. 6E).

Below and above of the facies anomaly interval (L4-L6), the pyrite content decreases and all statistical parameters increase (Figs 2P, 9). The populations of framboids in these intervals show a less consistent size distribution and contain large (up to $40 \mu \mathrm{m}$ ) framboids and framboid aggregates.
Interpretation. - Pyrite framboid size populations, combined with sedimentological observations, are very useful proxies of anoxic/euxinic conditions (Wignall \& Newton 1998, Bond et al. 2004). In the case of water column euxinia, the framboidal pyrite aggregates grow in the suspension up to a critical size of around $5 \mu \mathrm{m}$, after which they start to sink below the reduction zone, where their growth ceases (Wilkin et al. 1996). As a result, the framboids formed in euxinic conditions are, on average, smaller and less variable in size than the framboids formed below the sediment-water interface in anoxic sediment (Wilkin et al. 1996).

The statistical parameters of the framboid pyrite spheroids in the facial anomaly interval (L4-L6) are typical (Wilkin et al. 1996, Bond et al. 2004) of syngenetic pyrite (sensu Raiswell \& Berner 1985), formed in the water column and slowly settling on the sediment-water interface (Fig. 8). Abundant, randomly dispersed, minute framboids, considerably smaller than the other rock components, indicate the lack of winnowing processes on the sea bottom.

According to the presented data, during the formation of the carbonate-bearing facies anomaly, a considerable part of the lower water column was sulphidic (euxinic). The lack of framboids inside the "sparoids" indicates that the "sparoids" were formed above the sulphidic zone in oxic, near-surface conditions (Fig. 8).

Relative pyrite depletion in the "sparoid" (calcite)-rich laminae and layers (Fig. 9B-E) may suggest a higher rate of sedimentation during the calcite precipitation events, suggesting the rapid and mass character of the water-column "sparoid" formation events (whitings).

The internally pyritized calcite grains probably represent calcite aggregates containing entrapped organic matter, which caused development of an isolated internal sulphidic microenvironment.

Less consistent spheroid populations, with a contribution of larger framboids, occurring below and above the facies anomaly interval, suggest lower dysaerobic conditions 
with some fluctuations of the sulphide level in the bottom water-column. Strong pyrite depletion and the presence of only few large pyrite framboids in the top interval of the CIE, along with the local appearance of benthic fauna, suggest temporary oxic events on the bottom surface at the end of the studied event (Fig. 2).

\section{Event-related mineralogical anomalies in the light of XRD data}

The CIE-related facies anomaly is expressed in the mineral composition (Table 1, Fig. 2L) as a distinct positive excursion in dolomite contribution, closely linked with the pyrite size/contribution anomaly from the one hand (Figs 2P, 9), and followed after some delay by the rise in calcite admixture and CIE (Fig. 2L, N), on the other hand. The dolomite enrichment coincides (Fig. 2J) with the two-fold increase of Fe-poor dolomite (forming the detrital grain interiors) in relation to the ferroan dolomite (identified in the syntaxial rims).

The dolomite and quartz contents show coeval fluctuations in second-order trends (Fig. 2L), however, the first-order dolomite excursion is not coeval with the higher contribution of siliciclastic components (Fig. 2L). The dolomite positive excursion distinctly changed the composition of the detrital silt material, signalizing radical changes in provenance, well monitored by the dolomite/Q+F ratio (Fig. 2J). The dolomite admixture during the event is also not related to calcite (Fig. 2M). The oscillations in the dolomite/calcite ratio in the succession correspond to a similar variation of the QFC (quartz + feldspar + clay) / calcite ratio (Fig. 2M, N).

\section{Event-related facies: textural and compositional changes across the event interval}

The first concentration of the dolomite bearing silt is noted in complex L2 (Fig. 2C) as single laminae - $13.5 \mathrm{~m}$ below the "turning point" - in the middle part of the Neocucullograptus kozlowskii Zone (box/sample 364). The laminae locally contain admixtures, or are cemented by "sparoids" (noted here for the first time), which occur in a minor content in relation to the dolomite. The pyrite framboids are sparse at this level with a relatively wide range of spheroid sizes (Fig. 9A). The contribution of silt laminae gradually increases toward the top of complex L2.

In complex L3, the dolomite content temporally declines. In the levels enriched in dolomite (e.g. sample 357), the silt-bearing horizons contain abundant, consistent in size, minute-sized (below $5 \mu \mathrm{m}$; Fig. 9C) pyrite framboids. The co-occurring, subordinate calcite-bearing laminae contain prevailing "sparoid" flakes that enclose part of the detrital silt, however not incorporating the pyrite spheroids, which are volumetrically diluted (Fig. 9B).

At the level of the kozlowskii graptolite extinction (depth $854 \mathrm{~m}$, sample/box 355), the dolomite contribution rapidly increases, exceeding the previously achieved maximum level. The occurring above, $3 \mathrm{~m}$ thick, dolomite-bearing mudstones (L4) contain finely (up to $0.2 \mathrm{~mm}$ ), "double-acting" lamination (Fig. 6D), or less commonly show homogenous massive texture. The still accessorial calcite allochems occur mainly in the form of rafts and "sparoid"-dolomite clusters. The complex contains a maximum abundance of pyrite framboids, which are very consistent in size and reach the first minimum $(3.64 \mu \mathrm{m})$ in their average diameter (Figs 2, 9D).

In the upper part of bed L4 (box/sample 352), for the first time occur quite abundant microfossils classified as loricas of tintinids ("calpionellids"). The shells represents several varieties of regular vase-like shapes, reaching 100 to $150 \mu \mathrm{m}$ in size, with small pyrite framboid grapes, dolomite grains, or "sparoid" cementation often presented inside (compare Murray \& Taylor 1965). Below the "turning point", the fossils are thin-walled, weakly calcified, and internally agglutinated with very small detrital particles (Fig. 4F). Tintinids occurring above the "turning point" (box/sample 351) have distinctly thicker and well-calcified walls (Fig. 4G).

The high contribution of dolomite continues across the "turning point" with only a minor negative correction, whereas the calcite contribution radically increases (Fig. 2J, L, N). Above this rapid change, the $7 \mathrm{~m}$ thick bed of the dolomite-bearing calcisiltite (L5) is composed of unsorted "sparoid" and detrital grains, which form a predominantly massive, chaotic texture with distinct textural inversion (Figs 4A, 6A, B). Locally, relatively abrupt vertical changes in "sparoid" abundance and size, or horizontal zones distinctly enriched in detrital grains, result in a smooth horizontal lamination. Abundant calcite flakes are chaotically oriented, sometimes cracked or doubled-up,

Figure 5. Micrographs of stained thin-sections from the Mielnik IG-1 core, showing large calcite flakes. $\bullet$ A - fragment of calcite flake with incorporated dolomite grains truncated (arrowed) on the cluster margin (box/sample 352). $\bullet$ - fragment of flake with incorporated calcified dedolomite grain and rounded "sparoid" spheroidal cluster. $\bullet \mathrm{C}$ - fragment of elongated flake showing bidirectional growth pattern outward of the internal planar surface, white arrow indicates a "sparoid" spheroid, whereas red arrow indicates a spherical "sparoid" grain. •D - fragment of large, doubled-up, calcite flake with incorporated dolomite (yellow-coloured) and microstromatolite structure emphasized by laminae of microbial filaments inside the domes (white arrows), red arrow indicates axial planar surface of the grain; B-D - sample/box 351. 

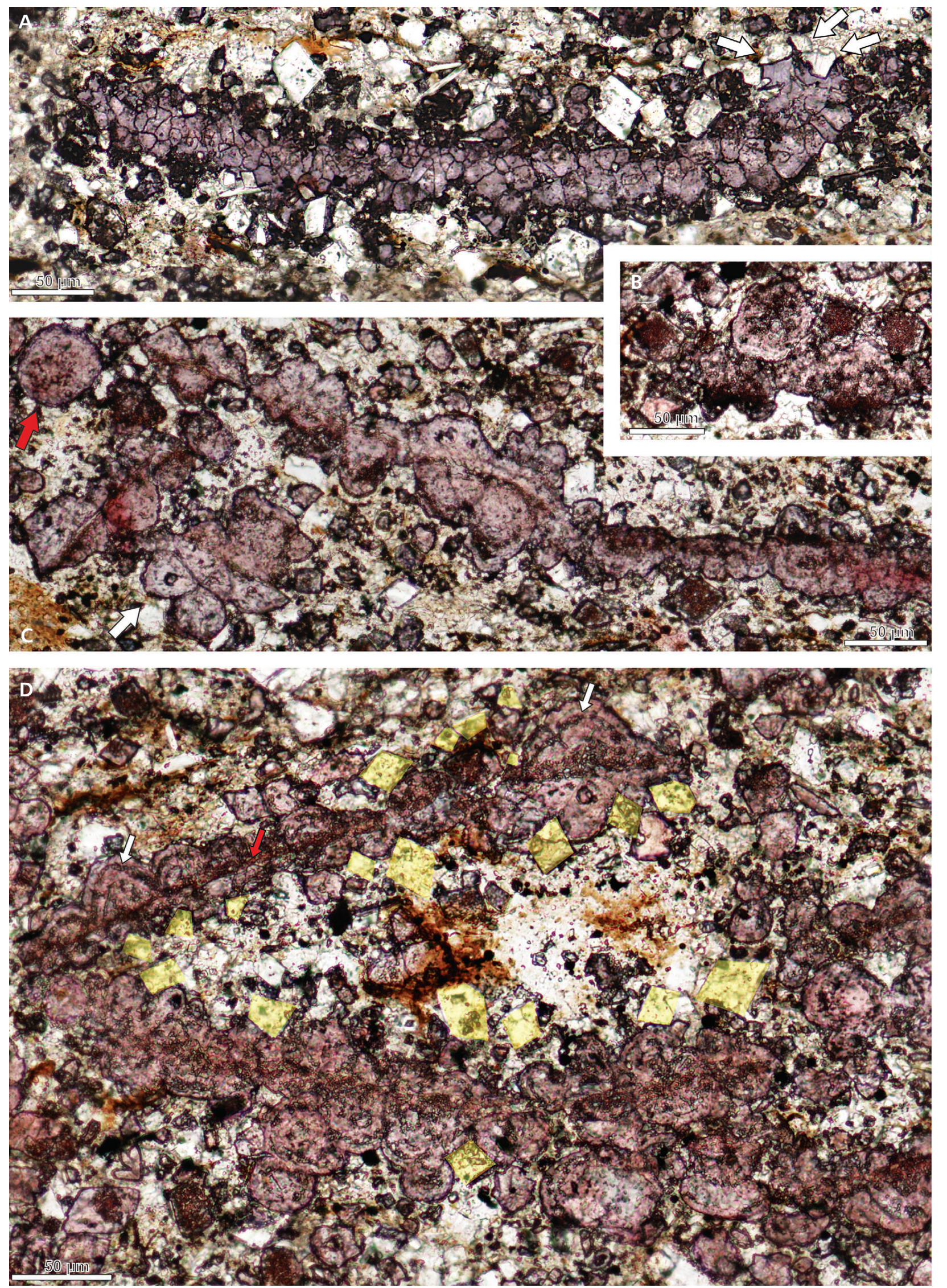
Table 2. Size-class distribution of pyrite framboids in the Mielnik IG-1 section, normalized to the area of $1 \mathrm{~mm}^{2}$.

\begin{tabular}{|c|c|c|c|c|c|c|c|c|c|}
\hline \multirow[b]{2}{*}{ Size classlsample } & \multicolumn{9}{|c|}{ Grains per $\mathrm{mm}^{2}$ (calculated) } \\
\hline & M364 & M357c & M357t & M352d & M351B & M350 & M348 & M345 & M343 \\
\hline $1-1.5 \mu \mathrm{m}$ & & & & 3 & 2 & & & 3 & \\
\hline $1.5-2 \mu \mathrm{m}$ & & & 3 & 19 & 6 & 6 & 9 & 6 & 1 \\
\hline $2-2.5 \mu \mathrm{m}$ & 1 & 3 & 25 & 50 & 63 & 23 & 34 & 15 & 7 \\
\hline $2.5-3 \mu \mathrm{m}$ & 1 & 25 & 48 & 97 & 86 & 42 & 102 & 30 & 13 \\
\hline $3-3.5 \mu \mathrm{m}$ & 15 & 31 & 93 & 157 & 63 & 85 & 142 & 45 & 16 \\
\hline $3.5-4 \mu \mathrm{m}$ & 22 & 16 & 80 & 91 & 69 & 45 & 72 & 44 & 7 \\
\hline $4-4.5 \mu \mathrm{m}$ & 17 & 31 & 35 & 63 & 29 & 33 & 45 & 42 & 10 \\
\hline $4.5-5 \mu \mathrm{m}$ & 19 & 35 & 68 & 35 & 13 & 22 & 38 & 27 & 4 \\
\hline $5-5.5 \mu \mathrm{m}$ & 10 & 50 & 28 & 22 & 13 & 26 & 18 & 18 & 3 \\
\hline $5.5-6 \mu \mathrm{m}$ & 15 & 13 & 30 & 6 & 2 & 4 & 13 & 9 & 4 \\
\hline $6-6.5 \mu \mathrm{m}$ & 6 & 19 & 8 & 6 & & 3 & 2 & 4 & 3 \\
\hline $6.5-7 \mu \mathrm{m}$ & 6 & & 18 & 9 & & 1 & 5 & 2 & 1 \\
\hline $7-7.5 \mu \mathrm{m}$ & 7 & 9 & 5 & 3 & & & 2 & 1 & 6 \\
\hline $7.5-8 \mu \mathrm{m}$ & 5 & 3 & 3 & & & & 2 & 1 & 7 \\
\hline $8-8.5 \mu \mathrm{m}$ & 3 & & & 6 & & 1 & 2 & & 4 \\
\hline $8.5-9 \mu \mathrm{m}$ & 1 & 3 & & & & & & & 7 \\
\hline $9-9.5 \mu \mathrm{m}$ & 1 & 3 & & 3 & & & & & 1 \\
\hline $9.5-10 \mu \mathrm{m}$ & & & & & & & & 1 & \\
\hline $10-10.5 \mu \mathrm{m}$ & & & & 3 & & & & & 1 \\
\hline \multicolumn{10}{|l|}{$10.5-11 \mu \mathrm{m}$} \\
\hline $11-11.5 \mu \mathrm{m}$ & & & & & & & & & 1 \\
\hline \multicolumn{10}{|l|}{$11.5-12 \mu \mathrm{m}$} \\
\hline $12-12.5 \mu \mathrm{m}$ & 2 & & & & & & & & \\
\hline$>12.5 \mu \mathrm{m}$ & 1 & & & & & & & & \\
\hline total & 132 & 241 & 444 & 573 & 346 & 291 & 486 & 248 & 96 \\
\hline investigated area $\left[\mathrm{mm}^{2}\right]$ & 0.96 & 0.32 & 0.4 & 0.32 & 0.48 & 0.7 & 0.56 & 0.89 & 0.89 \\
\hline grains counted (n) & 127 & 77 & 176 & 183 & 165 & 202 & 270 & 222 & 87 \\
\hline$\varphi_{\max }[\mu \mathrm{m}]$ & 15.7 & 9.2 & 7.8 & 10.5 & 6,0 & 8.1 & 8.1 & 9.8 & 11.8 \\
\hline$\varphi_{\min }[\mu \mathrm{m}]$ & 2.3 & 2.1 & 2,0 & 1.5 & 1.4 & 1.5 & 1.8 & 1.3 & 1.5 \\
\hline$\varphi_{\text {average }}[\mu \mathrm{m}]$ & 5.22 & 4.70 & 4.09 & 3.64 & 3.23 & 3.66 & 3.57 & 3.88 & 5.02 \\
\hline SD & 1.85 & 1.42 & 1.22 & 1.31 & 0.84 & 1.02 & 1.04 & 1.18 & 2.33 \\
\hline $\mathrm{SD} \%$ & 35 & 30 & 30 & 36 & 26 & 28 & 29 & 31 & 46 \\
\hline skewness & 1.59 & 0.74 & 0.67 & 1.94 & 0.57 & 0.89 & 1.33 & 0.83 & 0.66 \\
\hline calc. pyrite content $[\%]$ & 0.27 & 0.42 & 0.58 & 0.6 & 0.28 & 0.31 & 0.48 & 0.29 & 0.19 \\
\hline
\end{tabular}

whereas the numerous "sparoid chains" are crumpled, often with detrital grains sandwiched inside.

The pyrite spheroids in the calcisiltite bed (L5) are still abundant (but relatively diluted in relation to the underlying mudstones) and diminutive (Fig. 9E-G), reaching the second minimum of average diameter in the upper part of the bed. The single minute radial ooids were noted from the calcisiltite level (Kozłowski \& Sobień 2012).

The next $2.5 \mathrm{~m}$ complex of laminated calcisiltite (L6) is characterized by the presence of claystone intercalations and appearance of small ostracods. The dolomite content, as well as the pyrite contribution, starts to decrease (Figs 2, 9). With the diminishing of dolomite admixture, the contribution of "sparoids" rapidly decreases, however the high calcite content is retaining (Fig. 2L, N) by the appearance of fine bioclasts and regular micrite.

\section{Restored autochthonous carbon isotope record (calcite)}

The $\delta^{13} \mathrm{C}_{\text {bulk rock }}$ fluctuations show a distinct correlation 
with the obtained mineralogical composition of the samples. The local rapid drops in the dolomite/calcite ratio clearly coincide with the rapid rises in the $\delta^{13} \mathrm{C}_{\text {bulk rock }}$ values, whereas the relative dolomite enrichments are often coincident with a lighter isotope bulk rock signature (horizontal arrows in Fig. 2). The most pronounced increase in the $\delta^{13} \mathrm{C}_{\text {bulk rock }}$ values at the "turning point", interpreted earlier (Kozłowski \& Sobień 2012) as a rapid CIE onset, is correlated with the strong increase in calcite contribution (from $8 \%$ to $23 \%$ ), coeval with the minor drop in dolomite abundances from $22 \%$ to $18 \%$.

The calculated $\delta^{13} \mathrm{C}_{\text {calcite }}$ values show several distinct differences in comparison with the $\delta^{13} \mathrm{C}_{\text {bulk rock }}$ record (Fig. 2H). The $\delta^{13} \mathrm{C}_{\text {calcite }}$ shows an initial increase (up to $3 \%$ ) in the lower half of the Neocucullograptus kozlowskii Zone, which appears to be coeval with the appearance of the detrital dolomite admixture and first appearances of the "sparoids". In the next interval $(854-862 \mathrm{~m})$, the $\delta^{13} \mathrm{C}_{\text {calcite }}$ values decline (what is also noted in the isotope record of the calcite-bearing limestone intercalations) and show fluctuations in the range between 1 and 4\%o. Unlike the bulk rock isotope record, the pronounced rising limb of the CIE recorded in calcite starts at the kozlowskii extinction level (Fig. 2) and shows a stable rise across the whole facies anomaly, but with a distinct acceleration across the "turning point". The calculated maximum of $\delta^{13} \mathrm{C}_{\text {calcite }}$ values $(10.42 \%$ ) occurs in the uppermost part of the calcisiltite member (box/sample 346) in the top of the facies anomaly interval. In the following complexes (L6-L8), the $\delta^{13} \mathrm{C}_{\text {calcite }}$ values start to decrease, again with strong fluctuations in the range between 9.54 and $5.78 \%$. Estimations of the $\delta^{13} \mathrm{C}_{\text {calcite }}$ values within complex L9 show the possibility of temporal restoration of high $\delta^{13} \mathrm{C}_{\text {calcite }}$ values $(7.84 \%$ o) before their stable gradual decline to the pre-event level.

Interpretation. - The addition of a substantial amount of allochthonous carbonate material (dolomite) strongly influences the $\delta^{13} \mathrm{C}_{\text {bulk rock }}$ signatures. Aside from the isotopic composition of the syngenetically formed carbonates, the measured values obviously depend on the relative contribution of dolomite in the analysed carbonate fraction. The earlier emphasized (Kozłowski \& Sobien 2012) rapid increase in the $\delta^{13} \mathrm{C}_{\text {bulk rock }}$ signatures at the "turning point" is in fact an artefact of the rapid change in the mineralogical composition. The calculated $\delta^{13} \mathrm{C}$ of calcite more accurately reflects the carbon isotope ratios of autochthonous carbonate material (i.e. the basin signal). In the studied rocks, the most obvious calcite components, which probably dominate the calcite signal during the CIE, are the watercolumn precipitates ("sparoids", rafts). The very high (compare with fig. 7 in Frýda \& Manda 2013) maximal calculated $\delta^{13} \mathrm{C}_{\text {calcite }}$ values (10.42\%o) seem possible, because they are very similar to the maximum values obtained from the coeval (however formed in shallow-water restricted en- vironment) clearly microbially induced carbonates of Scania (11.2\% - Wigforss-Lange 1999). Both values are $2-3 \%$ o heavier in relation to the maximum $\delta^{13} \mathrm{C}$ values $(\sim 8.5 \%$ ) obtained from brachiopod shells from the mid-Ludfordian CIE interval of Gotland (Samtleben et al. 2000), which probably are close to the isotope composition of the DIC. The difference is probably caused by the typically heavier isotope signatures of microbially induced precipitates in relation to the $\delta^{13} \mathrm{C}$ of the DIC (Thompson et al. 1997, Gischler et al. 2007).

The pronounced fluctuations in the $\delta^{13} \mathrm{C}_{\text {calcite }}$ values noted below and above the facies anomaly, may suggest an important admixture of the second calcite component. Part of the lows fits to the position of the microcrystalline limestone beds, which are isotopically lighter (see Fig. $2 \mathrm{H}-$ marked as open squares) than the co-occurring calcareous claystones. The limestones contain abundant large pyrite grapes, calcite crystal fans and microbial filaments, and are sparse in organic matter (see fig. 7 in Kozłowski \& Sobień 2012). These episodically formed beds have been interpreted as composed of calcite, formed by the decomposition of organic matter by sulphate reducing bacteria (Kozłowski \& Sobień 2012). Intervals with rapid variations in the calcite isotope record (minor negative carbon isotope excursions) occur exactly below and above the event interval (regarded here as permanently euxinic); hence, they may represent the pre- and post-event fluctuation of euxinic/dysoxic conditions. In this model, the temporal availability of sulphates allowed the oxidation of the accumulated (during temporary euxinia), organic matter and the periodical formation of the ${ }^{12} \mathrm{C}$-enriched calcite.

\section{Discussion}

\section{Dolomite-bearing silt as wind-derived detritus}

Distinguishing between fluvial- and wind-derived silt as components of marine sedimentary rocks is of considerable importance in palaeoclimatic and palaeoceanographic interpretations. Despite progress in sedimentology and the growing recognition of the importance of eolian dust as a component of marine sedimentary successions (Stuut 2014), the early Palaeozoic records of eolian dust are very limited (e.g. Gabbott et al. 2010). The main reason for this situation is the lack of unequivocal, widely accepted proxies for discriminating wind-derived detritus deposited in marine offshore settings.

The most common and often the only used proxy is the grain size spectrum and bulk domination of the well-sorted silt component. The studied dolomite with a grain diameter in the range between 20 and $40 \mu \mathrm{m}$, corresponds well to the average size range of recent eolian grains (Stuut 2014) deposited on the sea surface in the Persian Gulf region 
(Clemens 1998), and ancient grains interpreted as eolianderived silt deposited in the sea (Fischer \& Sarnthein 1988, Loope \& Haverland 1988, Soreghan 1992, Carroll et al. 1998, Gabbott et al. 2010). The second often-used criterion is a suitable palaeogeographic setting; however, this clue is not necessarily conclusive.

A contrasting provenance (e.g. mineralogical composition anomalous for local hinterland), and a composition atypical for fluvial deposits are regarded as very promising features for eolian dust detection (e.g. Davies et al. 1997). In the studied case, the dolomite isotope signature curve is remarkably decoupled from the distinct positive CIE, typical for the entire basin, what clearly indicate extrabasinal origin of the dolomite. Moreover, the dolomite anomaly is coeval with the radical changes in the detrital provenance (dolomite/QF ratio). However, because of the widespread evidence for a coeval sea-level drop during the kozlowski/Lau Event, the contrasting provenance alone may be simply explained by the appearance of a dolomite source due to the emersion of the carbonate platform tops (with possibility of the fluvial-tidal transport of the carbonate detritus to the basin).

Despite this possibility, the composition of the studied detritus indirectly favours eolian transport. The dolomite spectrum consists of a mixture of grains with varying states of abrasion and diagenetic histories, suggesting a very low imprint of transportation processes and a vast, homogenized source area. The silt also contains a high contribution of flattened quartz and mica grains. Additionally, the material lacks redeposited grains characteristic of neritic carbonates (with the exception of minute radial ooids that often occur in eolian carbonates (see e.g. Brooke 2001), what suggests the bypassing of the littoral zone during the transportation process. The studied dolomite-bearing silt has a very similar composition (see Khan 1997) and dolomite grain characteristics (see Khalaf et al. 1979) to recent marine eolian-derived sediments of the Persian Gulf region and to certain ancient carbonate eolianites (e.g. Loope \& Haverland 1988). Despite these similarities, the appearances of detrital dolomite are not limited to carbonate eolianites (see Martire et al. 2014 and references therein). Hence, the mineralogical composition and sorting cannot be conclusive alone for the eolian transport of the detrital dolomite, which could also be derived by fluvial input (e.g. Lydal 1985).

Another important clues in the studied case is deposition of the grains from suspension and lack of signs of traction transport on the sea bottom (compare Gabbott et al. 2010), evidencing by the incorporation of the dolomite within the grains formed in the water column, textural inversion of the calcisiltite and presence of "double-acting" lamination.

However, aside from the settling of airborne detritus, another possibility is settling of the silt from a fluvial suspension plume. Both cases, however, should be distinguishable, owing to significant geometrical differences between the two types of plumes, potentially recorded in the texture of the settled sediment. Unlike the fluvial suspension plume, the deposition of eolian dust from a dust storm supplies material (distinctly better sorted) in considerably smaller amounts. The silt-sized mineral particles can form a short-lived, floating sea-surface skin (due to surface tension and limited wettability of the grains). The skin may be fixed by phytoplankton or mineral precipitation and texturally modified during the settling process. Hence, the eolian silt plume should be distinctly flat and condensed in comparison with the suspension plume formed by rivers or tides.

In this context, the possible evidences of dry deposition of the eolian silt are: (i) evidence of the overflowing of the surface layer of the sea by the well-sorted silt, (ii) evidence of transition of the silt across the water-air interface and flat geometry of the silt plume, and (iii) particles attached to the top surface of the floating objects.

In the studied case, the first issue is evidenced by the incorporation of dolomite grains into sea-surface related calcite precipitates (Fig. 5) induced by phytoplankton (compare Gabbott et al. 2010). The common incorporation of silt into rafts is caused by the preferential nucleation of calcite on the dust particles resting on the pool surface (Taylor et al. 2004).

This aspect could explain the seeming paradox of the presence of calcite rafts (recently occurring generally in tranquil water pools) in open-marine setting, where sea surface is usually disturbed by wind. The observed rafts contain abundant detrital components; hence the rafts formation was probably triggered by the silt influx pulses. It is crucial that the massive eolian dust settling preferentially occurs during dust storm cessation, in windless condition. As the dust provides nucleation sites in highly saturated water, it results in very fast rafts formation during post-storm calm conditions. It is worth considering, that the supply of the detritus by the riverine-influx induced suspension plume, or wet deposition of dust (contrary to dry eolian derivation), should

Figure 6. SEM backscattered-electron images of the Mielnik IG-1 samples. • A - crumpled "sparoid chain" in a chaotic texture of the dolomite-bearing calcisiltite (sample/box 350). $\bullet$ B - calcite flakes with incorporated dolomite (D), quartz (Q) and mica (M) grains; note truncated dolomite grain at the edge (arrowed) (sample/box 345). $\bullet$ C - separate containing abundant dolomite euhedral grains (sample/box 357). •D - "double-acting" lamina composed of dolomite (D) and quartz (Q); note common changes of component sizes in section, abundant minute-sized pyrite framboids (Py) and of calcite flakes (C) (sample/box 352). $\bullet \mathrm{E}$ - fragment of lamina composed of detrital grains overgrown by calcite, note calcite grain with numerous minute pyrite cubic crystals inside (white arrow), syntaxial rim of the Fe-enriched dolomite (grey arrow) and calcitized hollow in the dolomite crystal (black arrow) (sample/box 352). 


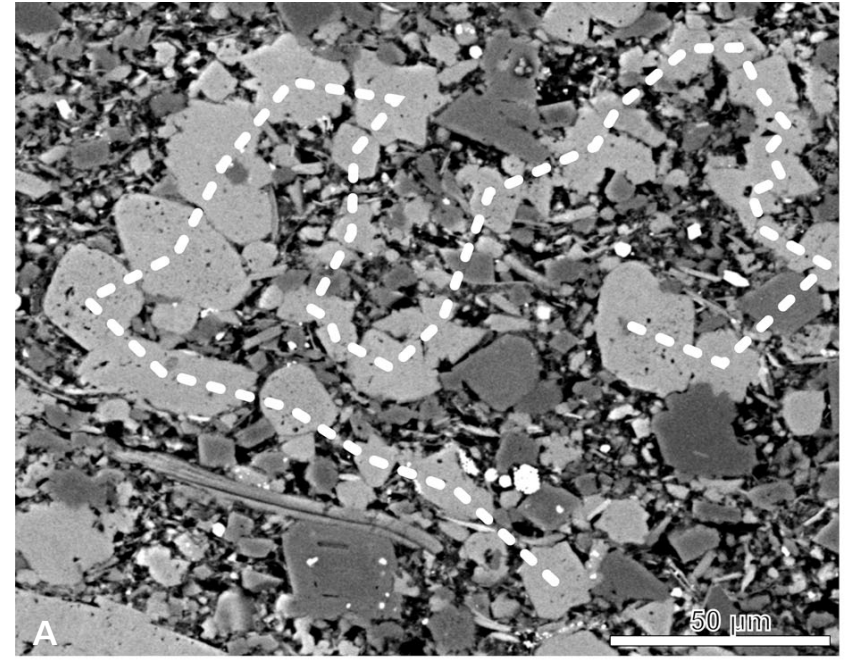

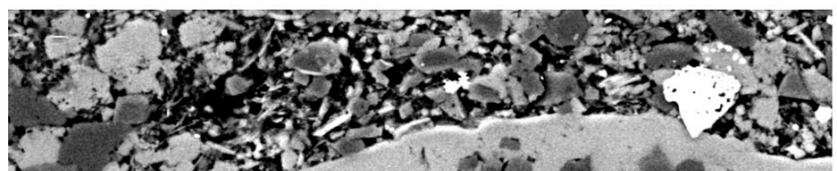

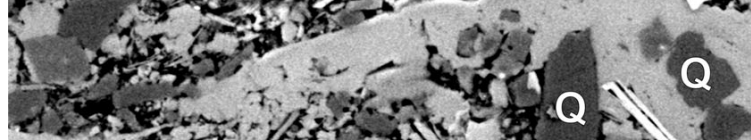
स. $132 \mathrm{Q}$. i 3 .

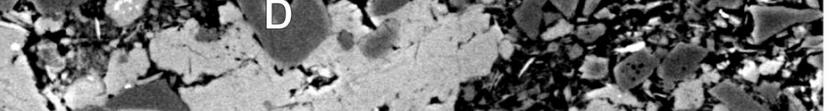

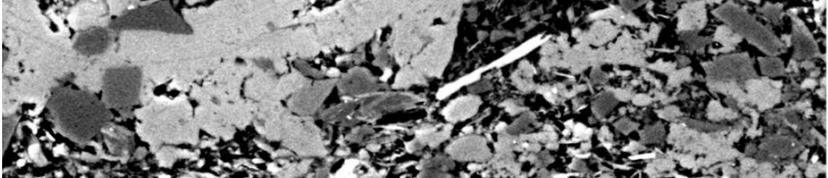

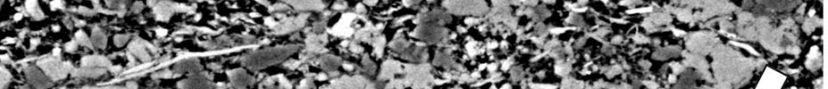

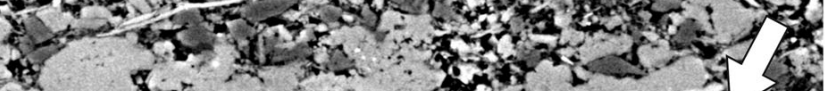

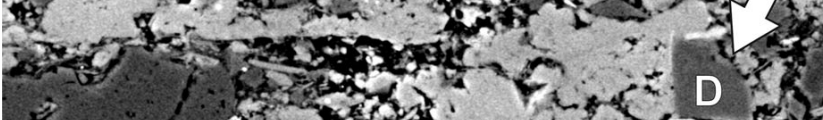

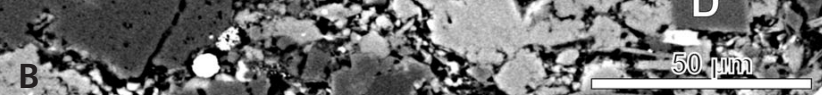

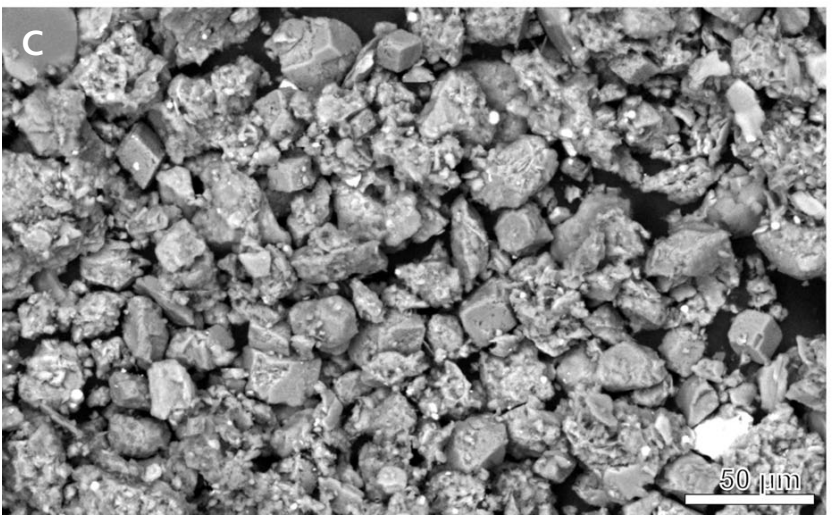

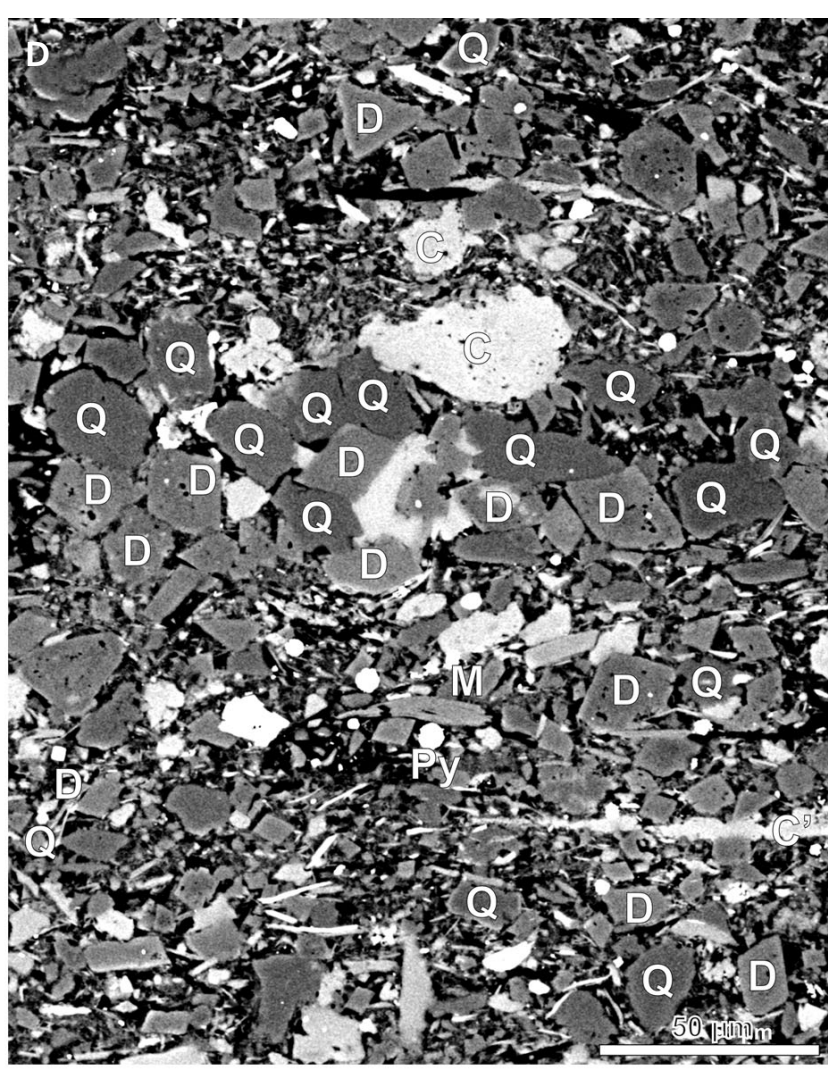

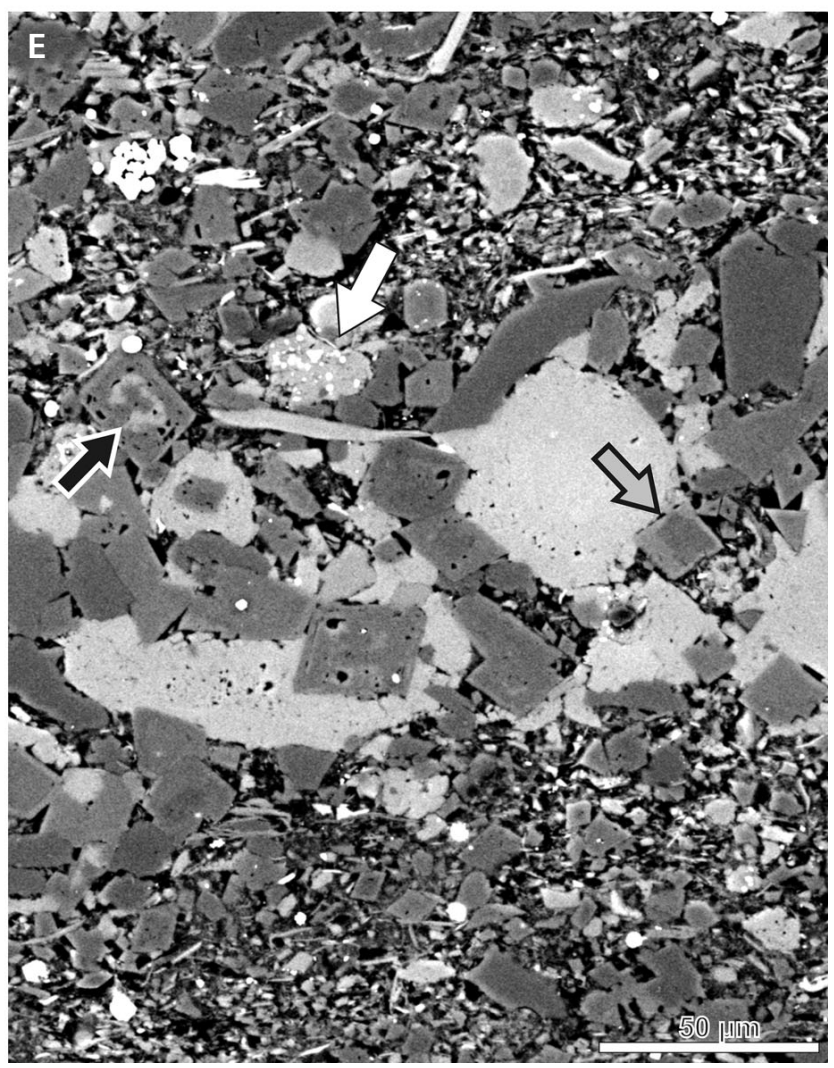


cause dilution of the surface-water saturation state, what would result in temporary cessation of the carbonate precipitation and prevention of the rafts formation after the silt influx pulse.

The second issue is evidenced by the "double-acting" lamination (Figs 6D, 7A), indicating settling of very small amount of grains from one level (surface skin), with a presumed density-dependent delay in the overcoming of the surface tension at the water-air interface (Fig. 8). The third case is evidenced by enclosure of silt inside the "ballasted aggregates" (Fig. 4B) and the presence of dolomite grains adhered to the top surface of the rafts (Fig. 7A).

The listed above textural features (evidences of silt overflowing, transition across water surface and settling on the floating objects) favor strongly eolian origin of the dolomite bearing silt. Observed contrasting provenance (anomaly in dolomite/QF ratio) along with material size and sorting could not be alone determinative for eolian silt distinction. These features, however, are very suitable for interpretation of the detrital dolomite as the eolian dust component. The presence of the substantial eolian admixture in the studied succession strengthens the earlier suggestions (Samtleben et al. 2000, Stricanne et al. 2006, Kozłowski \& Sobień 2012) of the possibly enhanced aridity and dustiness during the mid-Ludfordian CIE at least in the Baltica region.

\section{Possible drivers and triggers \\ of the CIE-related carbonate mass precipitation (whitings)}

The most spectacular aspect of the described facies anomaly is the mass appearance of "sparoids". The event bed was presumably deposited relatively very quickly, without larger breaks, which is indicated by its massive texture and lack of distinct omission surfaces. The observed pyrite dilution effect suggests a two-fold increase of the sedimentation rate across the "turning point".

Events of carbonate mass precipitation in the watercolumn of the sea, observed in the recent, are known as whitings (Cloud 1962, Broecker \& Takahashi 1966, Shinn et al. 1989, Robbins et al. 1997). The precipitated grains, composed of aragonite due to Recent seawater chemistry, are most often regarded as triggered by the bioactivity of phytoplankton (Wells \& Illing 1964, Robbins \& Blackwelder 1992, Thompson 2000). Other possible concurrent processes include the re-suspension of fine carbonate mud (Broecker \& Takahashi 1966, Morse et al. 1984, Boss \& Neumann 1993, Broecker et al. 2000, Morse et al. 2003) and physical precipitation of carbonates from temporally supersaturated water (Brunskill 1969, Strong \& Eadie 1978, Milliman et al. 1993). The most probable way of the marine whitings formation is the "intricate biophysicochemical coupling" of the above-mentioned processes (Thompson 2000).

Calcite whitings, comparable with "sparoid" mass formation, are recently known from hardwater lakes, where their formation is induced by picocyanobacterial activity (Stabel 1986, Thompson \& Ferris 1990, Thompson et al. 1997, Hodell et al. 1998, Ohlendorf \& Sturm 2001, Dittrich et al. 2004, Dittrich \& Obst 2004). However, the features of the studied ancient-marine "sparoids" suggest their more complex origin.

The relatively sparse calcite grains observed below the "turning point" occur mostly in the form of rafts. The precipitates consist of only single filaments and are formed preferentially on or between the detrital grains. In this case, the precipitation seems to be triggered by the deposition of the silt particles on the water surface (Fig. 8), which provided nucleation sites for the calcite (Taylor et al. 2004). In contrast, the "sparoids" above the "turning point" often do not include the detrital grains, but commonly contain tabular filaments inside individual crystals. During cyanobacterial photosynthesis, active uptake of $\mathrm{HCO}_{3}^{-}$ions is compensated by the expulsion of the $\mathrm{OH}^{-}$anions, causing calcite crystallization on the cell surfaces (Stabel 1986, Thompson et al. 1997, Riding 2006). In the studied case, the regular entombing of, often single, bacterial cells inside the "sparoids" indicates that the bioinduced calcite nanoparticles provide nucleation centres for the crystallization; however, the further crystal growth rate often surpasses the local bacterial activity. Hence, the grains are interpreted to have formed by the coupling of bioinduced nucleation and physical precipitation above the critical crystal size.

The possible trigger of the observed massive precipitation, concurrent with bioactivity, is the beginning of early transgressive conditions (Eriksson \& Calner 2008, Kozłowski \& Munnecke 2010) coeval with the "turning point" (Kozłowski \& Sobień 2012). The initiation of the reflooding of previously emerged carbonate platforms could have caused the restart of carbonate production and delivery of re-suspended carbonate nanoparticles ("physical whitings" of Boss \& Neumann 1993) and suspension of the reworked finest eolian material. Both types of nanoparticles would serve as nucleation sites for further calcite precipitation. Because sediment re-suspension may also trigger cyanobacterial blooms (Wainright 1987, Thompson 2000), the nutrient release during initial transgressive conditions could have an additional positive influence on the bioinduced nucleation of crystals.

Because the Palaeozoic tintinids record is very sparse and intermittent (Lipps et al. 2013), their abundant appearance in the "turning point" (as in a taphonomic window), confirm unusual conditions. The pronounced calcification of tintinid loricas above the "turning point" could suggest a 


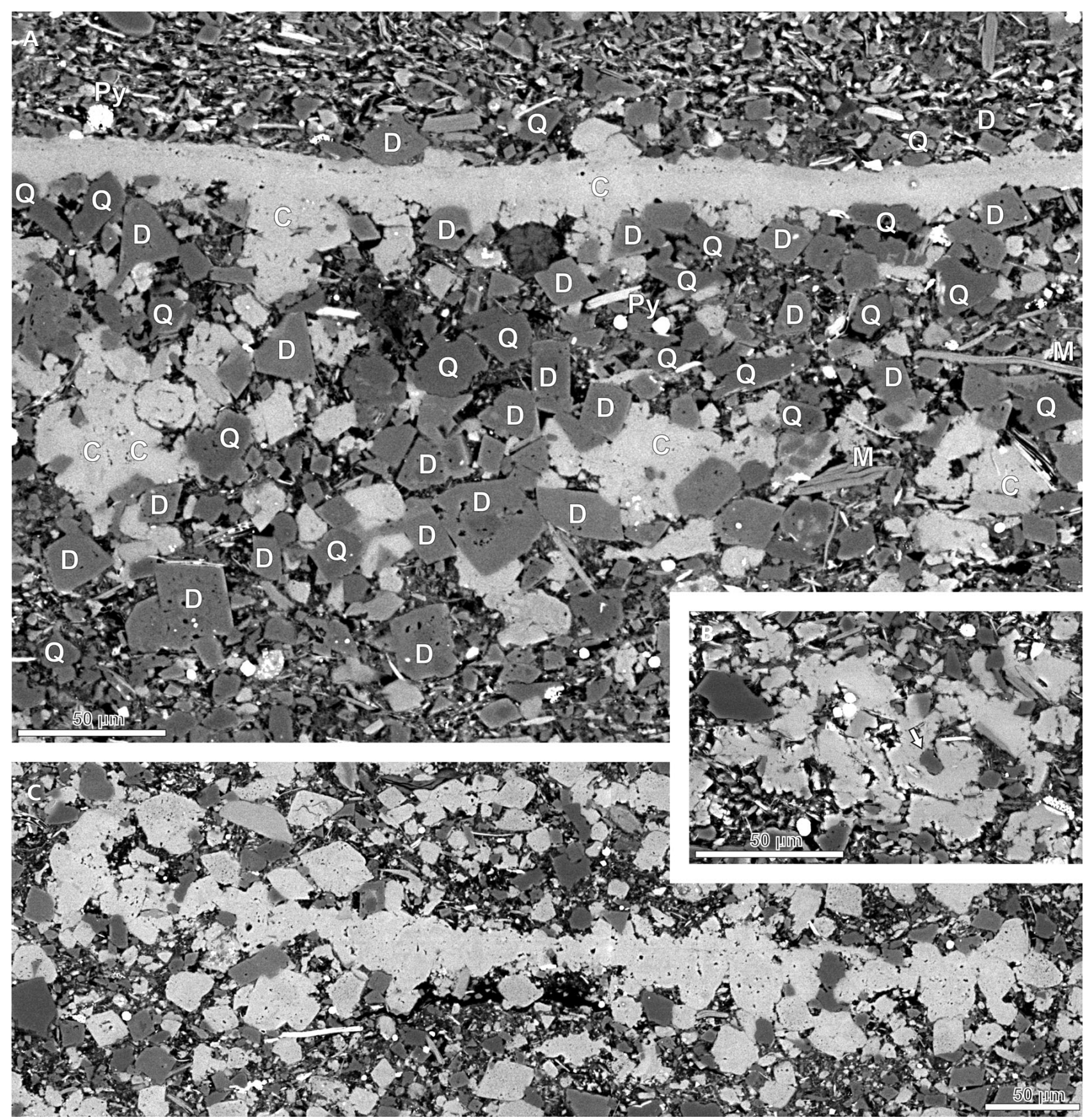

Figure 7. SEM backscattered-electron images of the Mielnik IG-1 samples. A - fragment of "double-acting" lamina with large (more than $2 \mathrm{~cm}$ long), asymmetric calcite flake in the top, interpreted as representing a calcite raft; note adhered grains on the top surface and dentate lower surface with incorporated detritus; mineral code as in Fig. 6 (box/sample 352). - B - lace-like growing texture of "sparoid"-like calcite cement; note occurrences of pyrite framboids preferentially occurring outside the calcite, whereas the dolomite grain is incorporated (arrowed) (box/sample 357$) \cdot \bullet^{\mathrm{C}}-$ complete calcite raft with edges rolled upward and preferential downward growth direction (box/sample 351).

rapid increase in the saturation state. On the other hand, the strong adaptation of recent tintinids to use any available mineral particles for the agglutination of their loricas (Henjes \& Assmy 2008), suggests that the observed changes in lorica mineralization may be a response to the appearance of suspended calcite nanoparticles of both de- trital and biochemical origin, additionally occurring in the hypersaturated water. The use of calcite nanocrystals for the agglutination of the loricas could cause their fast autocementation in a hypersaturated environment.

In each of the considered variants, calcite precipitation seems to be strongly dependent on the availability of 


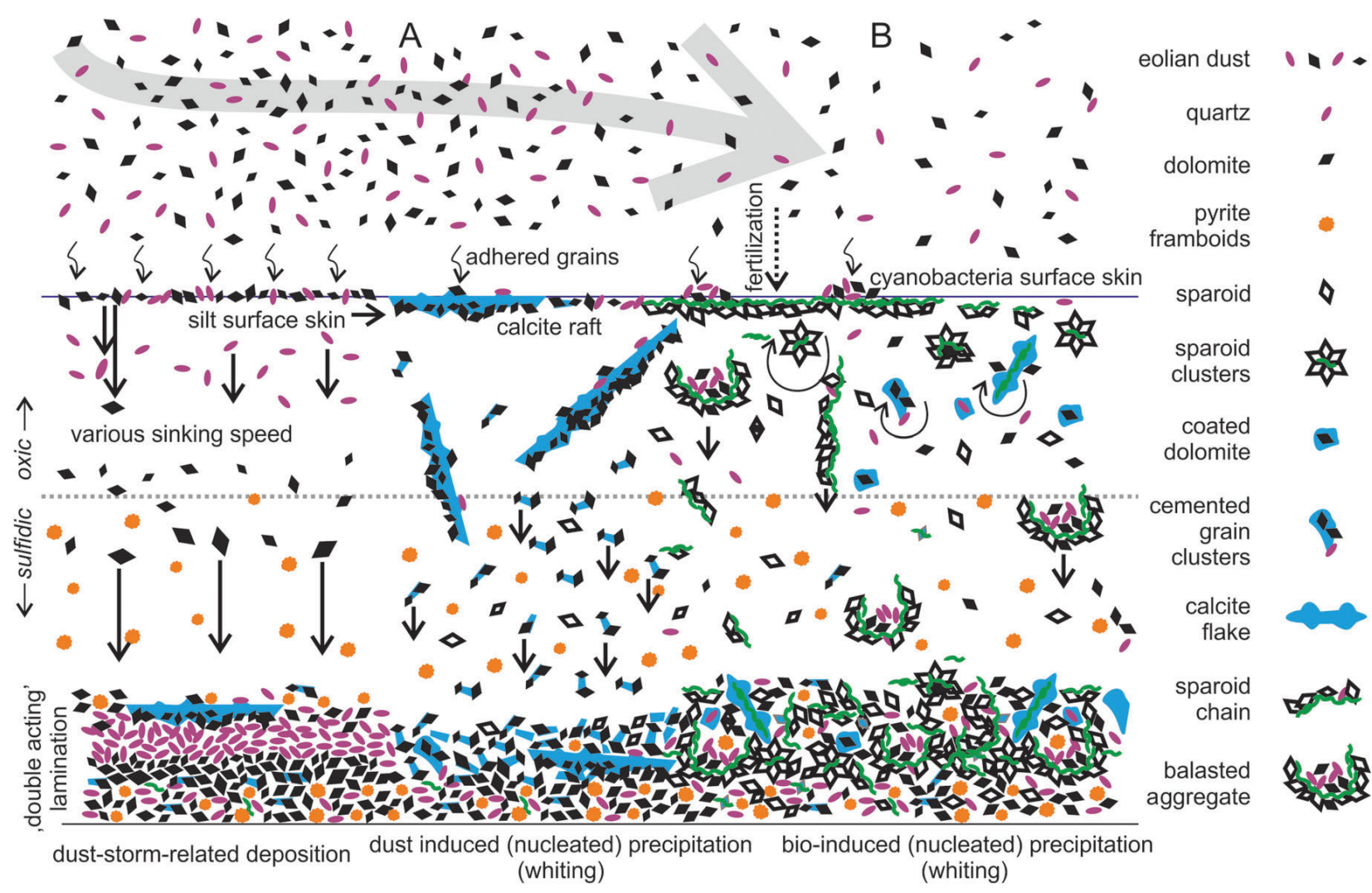

Figure 8. Schematic diagram depicting synthesis of the interpreted depositional processes and formation of A - the dolomite bearing mudstones as a result of the dust storm; B - sparoid bearing calcisiltite as a result of the succeeding whiting event.

nucleation sites both below and above the "turning point". The observations indicate the lack of spontaneous (homogenous) nucleation (which needs an extremely high $\Omega-$ Morse \& He 1993, Morse et al. 2003), and suggests a presumed additional presence of crystallization inhibitors in the seawater composition.

Regardless of the precise trigger, the rapid initiation and continuation of the mass production of the "sparoids" above the "turning point", needs an earlier surged carbonate saturation of the seawater. Enhanced saturation is crucial for the widespread chemical and biochemical-microbial precipitation and inducing of alkaline conditions enabling the proliferation of cyanobacteria (Kempe \& Kaźmierczak 1990, 1994; Riding 2006). The recent case of the marine-connected alkaline Satonda Lake, show that the enhanced state of saturation creates conditions favourable for proliferation of cyanobacteria (Kempe \& Kaźmierczak 1993, 1994). Throughout most of the Phanerozoic, microbial carbonates reveal a broad positive correspondence with the calculated seawater saturation state (Riding \& Liang 2005a). Riding (2005) pointed out the coincidence of the kozlowski/Lau Event facies anomalies with the predicted (Riding \& Liang 2005b), long-term, elevated saturation state during the late Silurian, with its maximum in the mid-Ludfordian. The rapid proliferation of reefs and car- bonate platforms with widespread formation of non-skeletal carbonates is one of the most spectacular features of the CIE intervals (Munnecke et al. 2003), which may be induced by the rapid discharging of the earlier surged saturation state.

A very meaningful case of such carbonate proliferation in the mid-Ludfordian CIE interval is the foundation of a short-lived carbonate platform on the foredeep clastic ramp in the southwestern margin of the studied basin. Temporal (CIE time-limited) carbonate sedimentation with formation of ooids (Kozłowski 2003) occurred there in an exclusively clastic setting (Kozłowski 2008), despite a pronounced sea-level lowstand (Kozłowski \& Munnecke 2010).

An anomalously high relative thickness of carbonates in the CIE interval was recently noted by Frýda \& Manda (2013) in the Kosov section in the Barrandian area. The authors suggested a long duration of the CIE plateau; however, very rapid carbonate production in hyper-saturation-related conditions is an alternative interpretation.

In the case of the Cellon key section in the Carnic Alps, the Alticolla Limestone (25 m thick - Brett et al. 2009), which represents a time span from the Lau Event base (Jeppsson et al. 2012) up to the top of the Ludfordian (Jaeger 1975), represents $46 \%$ (!) of the entire thickness of the 
stratigraphically "complete" Silurian; hence representing anomalous high rate of the carbonate production in the kozlowski/Lau Event interval.

\section{Possible causes of charging, latency and delay in the expression of the hyper-saturation state in the kozlowski/Lau Event interval}

As noted above, global changes in the saturation state are regarded as long-term processes (Riding \& Liang 2005a, b), which should not have driven the short-lived mid-Ludfordian event (Calner 2005b, Munnecke et al. 2010). However, the studied succession shows that, despite the surged saturation state before the "turning point" (documented by the occurrence of calcite rafts), there was a presumable mechanism preventing its earlier manifestation in the form of massive precipitation (lack of the trigger mechanism).

An initial increase in the dolomite silt contribution in the middle part of the Neocucullograptus kozlowskii Zone may be estimated as occurring at $\sim 125$ ka before the "turning point". The distinct coincidence between the general trends and positions of the maxima of dolomite and pyrite content suggest a close dependence of oxic conditions and eolian deposition. At the same time, the gradual appearance of the "sparoids" suggests a parallel rise of the saturation state in the basin.

Eolian dust is an important source of iron (Duce \& Tindale 1991) that stimulates the atmospheric nitrogen fixation by cyanobacteria (Falkowski 1997), which results in the increase of biological production of the sea surface (Martin \& Fitzwater 1988). Because the suspended/precipitated detrital compounds play an important role in the ballasting of the OM (Armstrong et al. 2001, Klaas \& Archer 2002), eolian dust may additionally increase the export of the OM from the surface to the depths (Fischer et al. 2009, Gabbott et al. 2010), favouring the formation of anoxic/euxinic bottom waters. The reduction of the mainly solid, insoluble Fe(III) oxides into well-soluble and highly bioavailable $\mathrm{Fe}$ (II) compounds in an anoxic environment has a positive feedback on surface bioproductivity. The possible dual role of eolian dust in the creation of euxinic conditions and in iron supply has a large potential in pyrite formation, which normally is strongly limited by the availability of iron (Berner 1982).

Kempe (1990) showed that during anoxic events, pyrite formation might generate a pronounced rise in the saturation state (and alkalinity) in the "sulphate to bicarbonate charge transfer" process (see also Hu \& Cai 2011). The charge transfer net reaction (4) is the sum of fundamental reactions (1-3) that occurred in anoxic conditions: 1) iron (III) oxide reduction; 2) sulphate reduction; and 3) pyrite formation (where $\mathrm{H}_{2} *$ may be exchanged into $\mathrm{CH}_{4}$, after addition of $1 /{ }_{4} \mathrm{CO}_{2}$ to the left side of the equation):

(1) $\left[\mathrm{CH}_{2} \mathrm{O}\right]+4 \mathrm{FeOOH}+7 \mathrm{CO}_{2}+\mathrm{H}_{2} \mathrm{O} \rightarrow$ $\rightarrow 4 \mathrm{Fe}^{2+}+8 \mathrm{HCO}_{3}^{-}$;

(2) $2\left[\mathrm{CH}_{2} \mathrm{O}\right]+\left(\mathrm{Ca}^{2+}\right)+\mathrm{SO}_{4}{ }^{2-}+2 \mathrm{H}^{+} \rightarrow \mathrm{H}_{2} \mathrm{~S}+2 \mathrm{CO}_{2}+$ $+2 \mathrm{H}_{2} \mathrm{O}+\left(\mathrm{Ca}^{2+}\right)$;

(3) $\mathrm{Fe}^{2+}+2 \mathrm{H}_{2} \mathrm{~S} \rightarrow \mathrm{FeS}_{2}+2 \mathrm{H}^{+}+\mathrm{H}_{2} *$;

(4) $17\left[\mathrm{CH}_{2} \mathrm{O}\right]+4 \mathrm{FeOOH}+\left(8 \mathrm{Ca}^{2+}\right)+8 \mathrm{SO}_{4}{ }^{2-} \rightarrow$ $\rightarrow 4 \mathrm{FeS}_{2}+\left(8 \mathrm{Ca}^{2+}\right)+16 \mathrm{HCO}_{3}^{-}+\mathrm{CH}_{4}+9 \mathrm{H}_{2} \mathrm{O}$

The doubled bicarbonate ion formation in relation to the sulphate sink, along with the doubled bonding of sulphur by a single atom of iron in the pyrite structure, makes reaction (4) very effective in the $\mathrm{CO}_{2}$ ocean sink and carbon storage in form of DIC ( 4 atoms of $\mathrm{C}$ per 1 atom of $\mathrm{Fe}$ ). The process (Fig. 10A) increases the seawater $\mathrm{pH}$ (exchange of the anion of a strong acid by the anion of a weak acid), which results in the increase of $\mathrm{CO}_{3}{ }^{2-}$ ion contribution in the surged DIC pool, which additionally amplifies the saturation state rise (for the summary of inorganic carbon chemistry see e.g. Ridgwell \& Zeebe 2005).

During the reduction of the substrates in reaction (4), large amounts of $\mathrm{OM}$ are consumed without a net increase of $\mathrm{CO}_{2}$ (hence without acidification). A similar process, localized on the bottom, would result in the formation of OM-poor, pyrite bearing, isotopically light limestones, which are present below the "turning point" in the studied section (Kozłowski \& Sobień 2012), and also marks the MFS above the CIE (Fig. 2). The limestone beds are bracketed by short-lived pronounced negative CIEs localized below and above of the long-lasting, positive CIE.

The second (hypothetical), concurrent mechanism of carbonate saturation increase is the dissolution of eolian derived carbonate dust in ocean depths (see Oba \& Pedersen 1999), which could occur outside the studied basin (Fig. 10A). The uniqueness of eolian transport lies in the mass delivery of carbonate particles to the ocean interior and their subsequent sinking toward the strongly undersaturated layer of bottom water (below the lysocline). Because during the early Palaeozoic the carbonate compensation depth was presumably much shallower than today (Boss \& Wilkinson 1991), a majority of eolian-derived carbonates could have been dissolved in this process. The potential ocean surface-water calcite precipitation due to the carbonate counter pump would result in the further re-dissolution of the sinking carbonate particles (Fig. 10A), hence the carbonate delivery would not cause net carbonate deposition in vast areas of the deep ocean (with the bottom below the $\mathrm{CCD}$ ) and would result in the effective storage of dissolved carbonates in the seawater in the form of $\mathrm{Ca}^{2+}$ 
and $\mathrm{HCO}_{3}{ }^{-}$ions (with a parallel atmospheric $\mathrm{CO}_{2}$ net invasion and sink). On the other hand, the rise in the saturation state should lead to the deepening of the CCD and the appearance of carbonate sediments in proximal/shallower oceanic successions (such as those containing the Ockerkalk facies in the upper Ludlow).

The effect of dissolution of carbonate bearing dust could concur with the additional influx of dissolved carbonates due to the emersion and chemical weathering of carbonate platforms (Fig. 10A) during the sea-level fall (see Holmden et al. 2012) that took place just below the mid-Ludfordian CIE.

The concurrence of various processes (pyrite formation, carbonate dust dissolution, carbonate platform weathering) required a parallel large-scale import of atmospheric $\mathrm{CO}_{2}$, which efficiently charged the ocean DIC reservoir (without acidification), with a gradual increase in alkalinity and calcite saturation state (Fig. 10A). However, the key factors for the formation of a cumulative hypersaturation state include not only effective charging, but also parallel strong limitation of the concurrent adequate carbonate discharge, i.e. carbonate sedimentation (Fig. 10A). According to the record of the kozlowski/Lau Event, two factors are worth considering as globally operating obstacles: (i) a sea-level fall (which preceded the CIE), and (ii) a high level of the precipitation inhibitors in the seawater.

The sea-level fall, could cause essential reduction of the extent of carbonate platforms (Fig. 10A), similar to that observed during the Last Glacial Maximum (Kleypas 1997). The low potential of the early Palaeozoic pelagic carbonate factory, along with the relatively shallow level of the CCD, could not compensate the diminishing of the carbonate platforms, which should cause a global drop in the total carbonate precipitation (see Ridgwell et al. 2003).

Despite the surged saturation state, carbonate production could additionally be slowed down by the high concentration of precipitation inhibitors (e.g. Pytkowicz 1965, Berner 1975, Meyer 1984). The high level of inhibitors, aside from the decreasing rate of crystal growth, caused the increase of the critical size of the nuclei. In such conditions, prevailing in the Precambrian (Sumner \& Grotzinger 1996), precipitation may occur preferentially on the existing crystals or the detrital grains (as in the studied case).

As shown above, a pronounced eolian influx to anoxic basins could increase the concentration of the $\mathrm{Fe}^{2+}$ ion, which is one of the strongest inhibitors of calcite precipitation (Meyer 1984, Dromgoole \& Walter 1990). The high contribution of dolomite in eolian dust dissolved in the ocean could result in the additional rise in $\mathrm{Mg}^{2+}$ concentration, which also inhibits calcite growth (Pytkowicz 1965, Berner 1975). On the other hand, progressive pyrite formation could lower the cumulative surge of the $\mathrm{Fe}^{2+}$ ion and decrease the concentration of the $\mathrm{SO}_{4}{ }^{2-}$ ion (less important calcite inhibitors - Meyer 1984). The foundation of new carbonate platforms with the beginning of transgressive conditions could have triggered the precipitation not only by the favouring conditions, but also by the seawater depletion in magnesium (due to neritic dolomitization), iron due to $\mathrm{Fe}^{2+}$ oxidation and transition into a solid state in the shallows and sulphates due evaporates formation.

\section{Causes of the CIE}

Based on previous work, the distribution and amplitude of the Silurian CIE's suggest that the anomalies probably had a non-whole-ocean nature (Melchin \& Holmden 2006, Loydell 2007, LaPorte et al. 2009, Holmden et al. 2012, Kozłowski \& Sobień 2012), but occurs as "spooky", synchronous events on independent carbonate platforms. On the other hand, the flat top of the $\delta^{13} \mathrm{C}$ curves with similar absolute values and regardless the palaeogeographic position, suggests that the detached in space "isotopic anomalies originated from the same global isotopic reservoir rather than being evolved independently within small restricted epeiric basins" (Frýda \& Manda 2013).

In the case of the detached CIE formation models the most likely driving forces of the $\mathrm{C}$-isotope fractionation are global sea-level changes, which probably synchronising the carbon isotope record of the spatially detached periplatform carbonate successions (Swart 2008).

The amplitude of the mid-Ludfordian CIE is largest in the semi-enclosed shallow water pools, with a long residence time, suggesting a dilution of the ${ }^{13} \mathrm{C}$-enrichment toward the open ocean (Loydell 2007). This extra ${ }^{13} \mathrm{C}$ contribution could be formed in two ways: (i) as derivation of heavy carbon from the land ("allochthonous CIE" - e.g. Melchin \& Holmden 2006); or (ii) by local large scale loss of the ${ }^{12} \mathrm{C}$ from the DIC pool ("residual CIE" - e.g. Holmden et al. 2012, Kozłowski \& Sobień 2012).

The "allochthonous model", known as the "weathering hypothesis" (Kump et al. 1999, modified by Loydell 2007, after Melchin \& Holmden 2006) assumes the input of ${ }^{13} \mathrm{C}$-enriched DIC from subaerial weathering of carbonates that emerged due to sea-level fall. This model is problematic because of the amount of the theoretically derived heavy carbon for the fast creation of a large CIE (Cramer \& Munnecke 2008). Another possibility, which could be taken into consideration, is the eolian supply of heavy carbonates formed in extremely arid conditions (see Nakai et al. 1975, McFadden et al. 1998, Quade et al. 2007); however, the light isotopic signatures of eolian dolomites exclude this mechanism in the studied case.

The simplest "residual" model is the local deposition of OM occurring parallel to the carbonate sedimentation (Ghienne et al. 2014). As noted above, the mid-Ludfordian CIE interval contains a significant amount of OM, however (surprisingly), just below the CIE. During the CIE in the 
studied case, despite the euxinic conditions on the bottom, OM enrichment is paradoxically not noted. This suggests a large-scale oxidation of OM in the water column (above the sulphidic zone) by sulphate-bicarbonate charge transfer and/or decomposition of the OM to methane.

The "methane ebullition" model (Kozłowski \& Sobień 2012), considering ocean-atmosphere fractionation, is promising, because the methane ebullition allows for the formation of ${ }^{13} \mathrm{C}$-enriched limestones, without the necessity of the deposition of the organic rich sediments (see Curry et al. 1997, Hassan 2014). On the other hand, the model does not explain the synchronicity between the CIE and carbonate mass precipitation described in this paper.

Based on the coupled records of $\mathrm{Ca}$ and $\mathrm{C}$ isotopes during the Hirnantian glaciation, Holmden et al. (2012) proposed the eustatically driven "submarine groundwater discharge" (SGD) mechanism of the CIE formation. The SGD from the dissolved, exposed top of the carbonate platform provides brines supersaturated with carbonates. In the model, the high abundance of the DIC stimulates photosynthesis, which leaves the residually ${ }^{13} \mathrm{C}$-enriched sedimentary carbonates. The model fits well with the assumed decoupling (Holmden et al. 1998) between the ocean and shelf carbon isotope record, and larger amplitude of the CIE in the long-residence-time water pools (Kozłowski \& Sobien 2012). However, from the perspective of the studied event, the model is negatively tested by the CIE in the Holy Cross Mountains of Poland (Kozłowski \& Munnecke 2010). In this region, a pronounced CIE (8.9\%) occurs in carbonates occurring only in the CIE interval and formed along an entirely carbonate-free hinterland (Kozłowski 2008, Kozłowski et al. 2014).

\section{"Carbonate reflux" hypothesis}

In the presented hypothesis, the resumption of carbonate sedimentation synchronized by eustasy and ocean geochemistry appeared rapidly in hypersaturated (strongly charged) ocean conditions (Fig. 10A). Widespread expansion of accommodation space due to the early-transgressive

Figure 9. Histograms (in stratigraphic order) showing the distribution and abundances of framboidal pyrite in individual class sizes; note rapid drop of pyrite abundance above sample 352 (D/E - "turning point"). The decline, which is interpreted as the result of double-fold increase in the sedimentation rate due to mass calcite precipitation; is parallel to the paradoxical continuation of framboid diameter decrease. Pyrite abundance increases again at the end of the calcisiltite interval, presumably because of decrease in the precipitation rate (G). Samples: A - M364; B - M357-"sparoid" rich lamina; C - M357-"sparoid" poor lamina; D - M352d; E - M351B; F - M350; G - M348; H - M345; I - M343 grey diagram - use enlarged vertical scale.

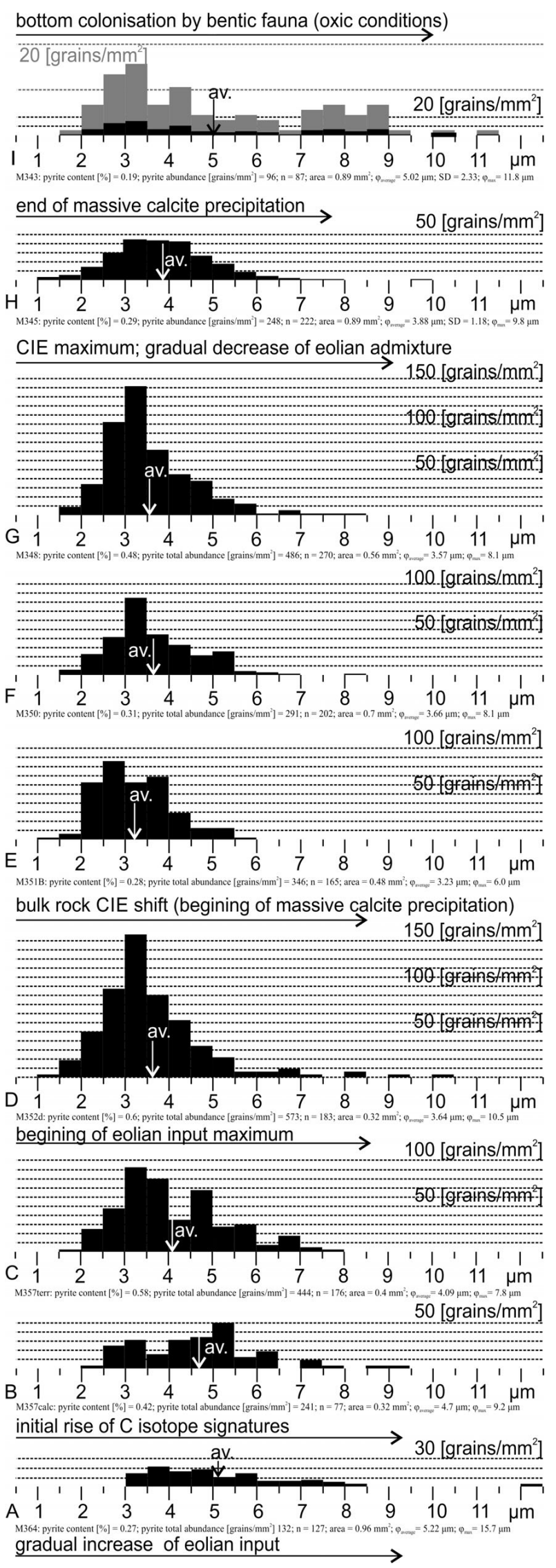


conditions in the neritic zone, and impoverishment of inhibitors in the pelagic zone, trigger the massive reanimation of carbonate precipitation according to the equation:

$$
\mathrm{Ca}^{2+}+2 \mathrm{HCO}_{3}^{-} \rightarrow \mathrm{CaCO}_{3}+\mathrm{CO}_{2}+\mathrm{H}_{2} \mathrm{O}
$$

The process releases the previously uptaken/created $\mathrm{CaCO}_{3}$ and $\mathrm{CO}_{2}$, and hence, in fact is a "reflux" of both compounds (Fig 10B). Despite the buffering capacity of the carbonate system, the $p \mathrm{CO}_{2}$ of local seawater pool increases during intensive carbonate precipitation, thus the $\mathrm{CO}_{2}$ must be net-exported (Ridgwell \& Zeebe 2005) to other reservoirs (atmosphere, biosphere or lithosphere through biosphere). The transfer of the surplus of $\mathrm{CO}_{2}$ may occur in different ways, but every possible mechanism (biosphere uptake and mineralization, methanogenesis, $\mathrm{CO}_{2}$ degassing or methane ebullition) assumes strong kinetic isotope fractionation. Swart (2008) noted that the massive carbonate production on the carbonate platform tops, in the case of the long residence time of the water pools, might cause ${ }^{13} \mathrm{C}$-enrichment of carbonates due to the abundant photosynthesis and net $\mathrm{CO}_{2}$ degassing.

Because of the prevailing lack of the coeval organic rich sediments in the studied interval, the simplest carbon loss mechanism is the physical degassing of excess $\mathrm{CO}_{2}$ (with fractionation based on the Rayleigh isotope distillation model), or concurrent methane ebullition. If the carbonate formation were sufficiently fast, kinetic fractionation would prevail over the isotope equilibrium process. The formation of residual, progressively ${ }^{13} \mathrm{C}$-enriched DIC pool will influence the isotope signatures of both carbonates and $\mathrm{OM}$.

A recent analogue of such kinetic fractionation is the formation of ${ }^{13} \mathrm{C}$-enriched carbonates in the Andean Antiplano lakes in Argentina (Valero-Garcés et al. 1999). In this case, the lakes are supplied with relatively ${ }^{13} \mathrm{C}$-depleted $\mathrm{CO}_{2}$, derived from an endogenic source. The $\mathrm{CO}_{2}$ dissolving in bottom waters causes enlargement of the DIC (equivalent of an "unlimited" ocean DIC reservoir during the CIE). However, the rise of $p \mathrm{CO}_{2}$ (equivalent of the massive calcite precipitation) causes surficial degassing with preferential loss of ${ }^{12} \mathrm{CO}_{2}$. As a result, the residual DIC and the precipitated carbonates reach $\delta^{13} \mathrm{C}$ values of $+13 \%$ o (vs. PDB).

In the proposed model, the global ocean DIC reservoir may be regarded as remaining in equilibrium with the atmosphere, achieved by the long lasting, relatively slow charging processes $\left(\mathrm{CO}_{2}\right.$ invasion). In contrast to the saturation charging, which potentially occurred on the entire ocean surface, the discharge would be restricted (Fig. 10B) and detached in space and accelerated in time. The poolatmosphere evasion of the $\mathrm{CO}_{2}$ will concentrate in "chimneys" within the carbonate factory, ensuring efficient kinetic isotope fractionation of residual DIC pools. Hence, the model may be equated to the (amplified and temporally extended) recently observed, $\delta^{13} \mathrm{C}_{\mathrm{DIC}}$ differences, occur- ring between $\mathrm{CO}_{2}$-invasion areas and $\mathrm{CO}_{2}$-evasion areas of the ocean surface (Lynch-Stieglitz et al. 1995).

Despite global synchronization, each "local CIE" would be driven by local circumstances. The $\delta^{13} \mathrm{C}$ of the local DIC pool in the proposed model is directly proportional to the local rate of carbonate formation (depending on climate, subsidence/accommodation space, riverine and nutrient influx, etc.) and water-pool residence time (restriction in circulation with the non-fractionated ocean reservoir), and inversely proportional to the size of the influenced DIC sub-reservoir (depth, non-carbonate facies contribution, etc.).

The flat top of the $\delta^{13} \mathrm{C}$ curves - reaching very similar absolute values in carbonate platform successions in Perunica, Baltica and Australia (see fig. 7 and discussion in Frýda \& Manda 2013) needs additional explanation. It may be speculated that despite the palaeogeographical detachment the carbonate platforms could subject to common global control factors. Synchronous, eustatically driven creation of new accommodation space allowed similar rate of the carbonate production, with the use of one, globally unified ocean reservoir of bicarbonates. The similar intensity of kinetic fractionation was coupled with the similar counteracting force of the atmosphere-sea $\mathrm{CO}_{2}$ exchange, which leading to isotopic equilibrium. The sum of both factors could result in similar maximal absolute $\delta^{13} \mathrm{C}$ values. In is important to note that according to the model, in the case of the local collapse of the carbonates production, rapid return to equilibrium between the atmosphere and the seawater could result in earlier termination of the CIE.

Because the efficiency of the carbonate factory decreases basinward, parallel to both increase of depth and decrease of residence time, the CIE would diminish offshore. Hence in the model, the CIE should be absent far away from the carbonate platforms (e.g. high-latitude shelves) or above ramps with enhanced circulation (carbonate pelagic successions). The ${ }^{13} \mathrm{C}$-enriched water, potentially delivered to the open shelf, would be diluted by the prevailing ocean water with non-fractionated DIC.

The maximal $\delta^{13} \mathrm{C}$ values calculated for the calcite (10.42\% o vs PDB) noted in this work from periplatform facies, do not confirm expected and signalized earlier (Kozłowski \& Sobień 2012) offshore decline of the mid-Ludfordian CIE amplitude in the studied basin. However, this seeming contradiction may be due the palaeographical circumstances of the basin, which in Ludlovian evolved into semi-enclosed Caledonian foreland (Kozłowski 2003). This should cause high residence time of the water pool, what along with documented here surface-water precipitation events could cause the isotope fractionation of the DIC in the entire basin during the studied event. It is important to note that the foreland basins with widespread carbonate production often contain relatively ${ }^{13} \mathrm{C}$-enriched carbonates (recent Persian Gulf Gischler et al. 2007, Miocene Parathetys Sea - Harzhauser 


\section{A - charging of the saturation state during the sea-level fall coupled with the enhanced dustiness (glacial period)}

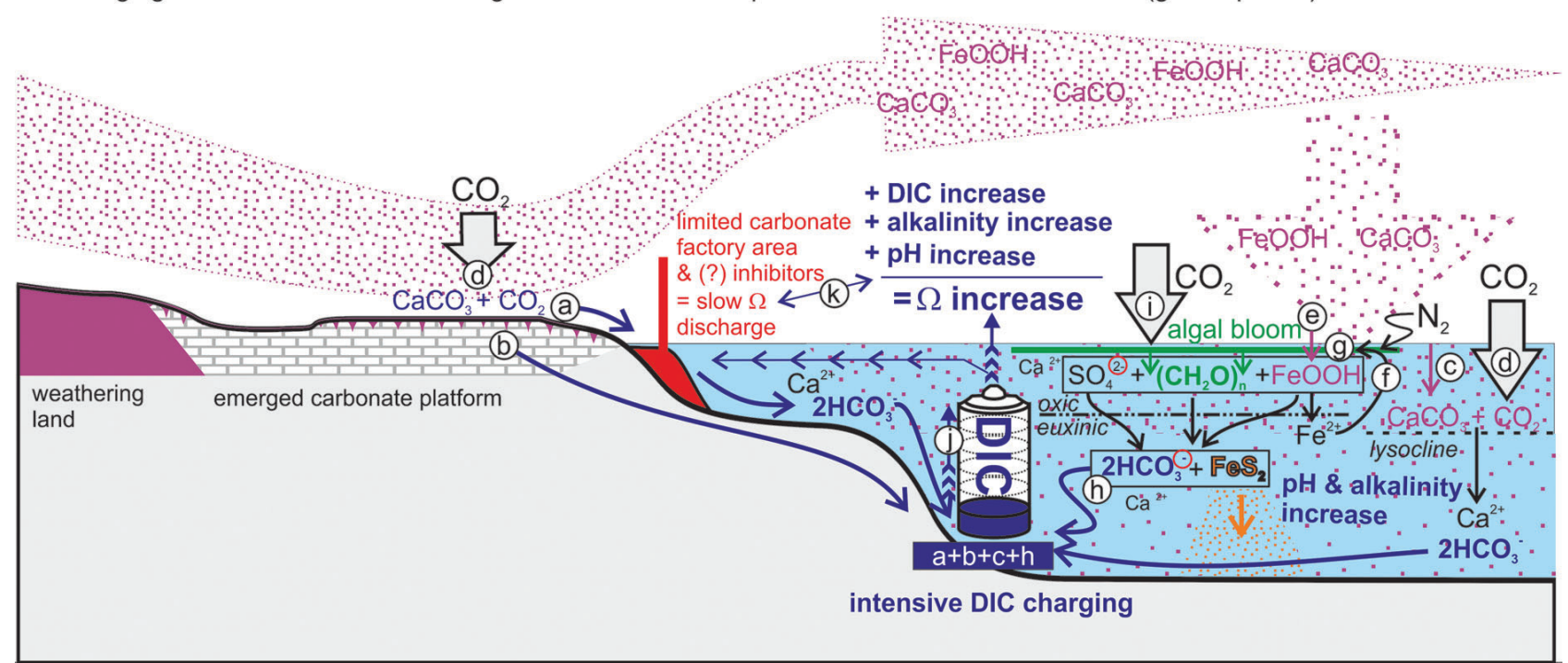

$\mathrm{B}-\mathrm{CIE}$ formation by the rapid discharging of the carbonate supersaturation state during transgression

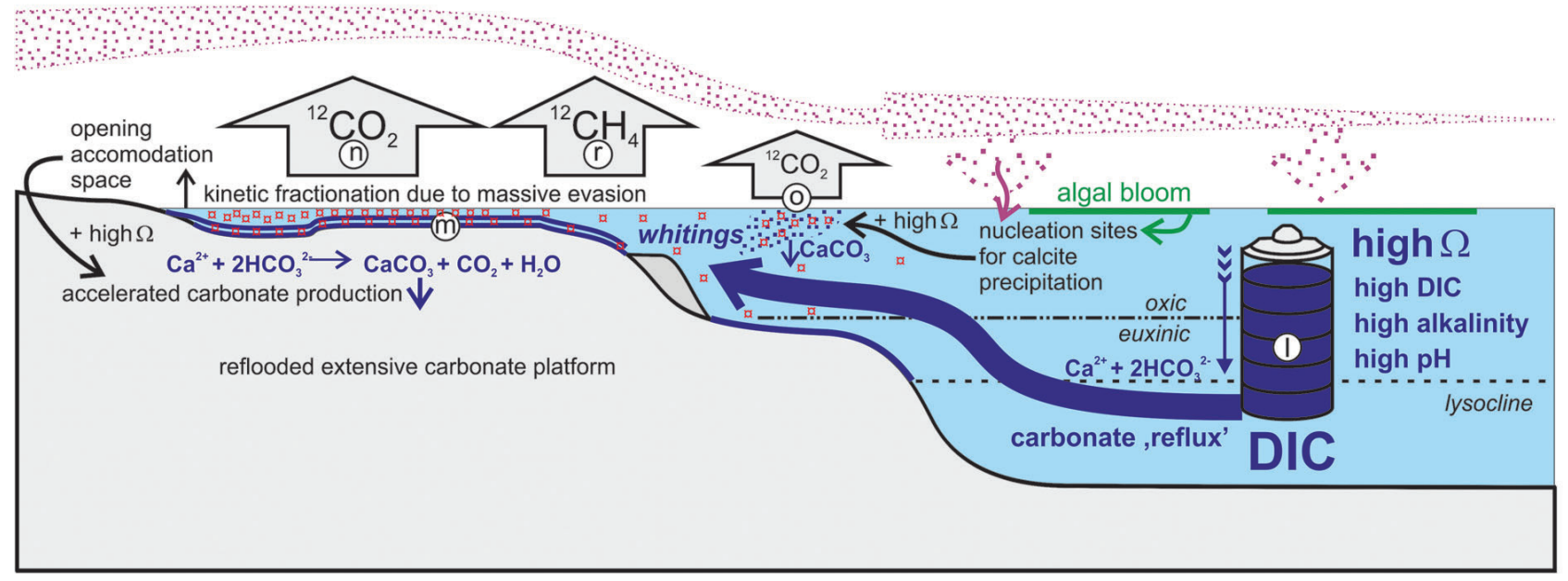

Figure 10. A hypothetical palaeoceanographic (early Palaeozoic) model for the concurrent multi-way development of the supersaturation state during the glaci-eustatic sea-level fall (A); followed by (B) the formation of a synchronous, spatially detached CIE due to massive carbonate precipitation on reflooded carbonate platforms. Model based on several earlier (Berger \& Keir 1984, Kempe 1990, Opdyke \& Walker 1992, Falkowski 1997, Oba \& Pedersen 1999, Valero-Garcés et al. 1999, Ridgwell et al. 2003, Riding 2005, Melchin \& Holmden 2006, Loydell 2007, Swart 2008, Holmden et al. 2012 , Kozłowski \& Sobień 2012) ideas, hypotheses and observations.

(A) During sea-level fall, weathering of the emerged neritic carbonate platforms delivers bicarbonate rich brines (Opdyke \& Walker 1992) by surface runoff (a) and submarine groundwater discharge (b; Holmden et al. 2012). Additionally, bicarbonates are formed by the mass dissolution of carbonate dust (c) in the deep ocean (Oba \& Pedersen 1999). Both ways of carbonate dissolution result in a huge sink of atmospheric $\mathrm{CO}_{2}(\mathrm{~d})$. The mechanism concurs with the "sulphate-bicarbonate charge transfer" (Kempe 1990) during pyrite formation, which is predicted to be enhanced in the case of a large-scale eolian iron supply (e). Wind derived iron, reduced in anoxic conditions, becomes highly bioavailable and thus strongly influences (f) nitrogen fixation (Falkowski 1997), which causes phytoplankton blooms (g) providing organic matter for the further reduction of iron and sulphates. The net pyrite formation process $(\mathrm{h})$ results in the massive transformation of organic matter into bicarbonate anions, which compensate the charge of the consumed sulphates according to the net equation: $17\left[\mathrm{CH}_{2} \mathrm{O}\right]+4 \mathrm{FeOOH}+8 \mathrm{SO}_{4}{ }^{2-}>4 \mathrm{FeS}_{2}+16 \mathrm{HCO}_{3}{ }^{-}+\mathrm{CH}_{4}+9 \mathrm{H}_{2} \mathrm{O}$. The continued net sink of organic matter in the reaction needs additional $\mathrm{CO}_{2}$ net invasion (i). The sum of bicarbonate formation processes $(\mathrm{a}+\mathrm{b}+\mathrm{c}+\mathrm{h})$ charges the DIC reservoir of the ocean $(\mathrm{j})$ and causes increase in seawater alkalinity. Exchange of the sulphate anion into bicarbonate anions causes distinct increase in seawater pH. The coupled rises of DIC, alkalinity and $\mathrm{pH}$ strongly increase the saturation state $(\Omega)$. The narrow area occupied by carbonate sedimentation during lowstand (Ridgwell et al. 2003) and the high concentration of precipitation inhibitors ( $\left(\mathrm{Fe}^{2+}\right)$ limit the $\Omega$ unload and cause its surge $(\mathrm{k})$.

(B) According to the "coral reef hypothesis" (Berger \& Keir 1984, Opdyke \& Walker 1992), with the beginning of a transgression, the dissolved carbonates stored in the ocean (1) may rapidly precipitate on individual, sparsely distributed, reflooded carbonate platforms (m). This "carbonate reflux" causes large-scale, synchronized in time, but scattered in space, concentrated evasion of $\mathrm{CO}_{2}\left(\right.$ and/or $\left.\mathrm{CH}_{4}\right)$ to the atmosphere (n), coupled with a strong kinetic isotope fractionation of residual DIC (compare Valero-Garcés et al. 1999; red circles represent residual heavy carbon). The process is globally synchronized with eustatic and seawater chemistry changes. According to the model, the amplitude of locally observed CIEs depends on the local carbonate precipitation rate and the residence time of local seawater pools. Hence, the residual effect is expected to be most efficient in water pools occurring on the tops of extensive neritic carbonate platforms $(\mathrm{m})$ or very rapid mass carbonate precipitation events (whitings) in relatively isolated water pools (o). 
et al. 2007, Permian Zechstein Basin - e.g. Peryt \& Peryt 2012), what seems to confirm the high influence of the carbonate precipitation dynamics on the $\mathrm{C}$-isotope record, hence high potential of the "reflux model" in formation of the CIE's.

\section{Conclusions}

It was pointed out (Cramer \& Munnecke 2008, Munnecke et al. 2010) that the observed facies, biotic and geochemical changes during the Silurian events are not the immediate results of the CIE formation mechanism, but rather all perturbations are the result of correlated processes that had occurred shortly before. The mid-Ludfordian CIE seems to be a repercussion of earlier, important environmental changes, less spectacularly manifested in the rock record. These perturbations were recognized for the first time by Schönlaub (1986) as the "Cardiola Event" in the Silurian of the Carnic Alps and according to present knowledge are the results of minor glaciations in high latitudes (Lehnert et al. 2007a). In the type area of the "Cardiola Event", Brett et al. (2009) interpreted the interval as representing anoxic conditions occurred during the sea-level highstand. However, if the Alticolla Limestone represents a rapid carbonate formation in post-glacial, early transgressive conditions, then at least the upper part of the Cardiola Formation could represent a cessation of the carbonate factory related to the glacioeustatic regression.

According to this study, in the studied basin, the "Cardiola Event" interval records the formation of an euxinic environment during the glacioeustatic regression, in response to the enhanced eolian input, which begins around $125 \mathrm{ka}$ before kozlowski/Lau Event. The beginning of the culmination of dust deposition and sulphidic conditions was coincident with the kozlowskii (graptolite) and Lau (conodont) extinctions. It seems very probable that the deep-water organisms were affected by the development of permanent euxinic conditions, occurring during the sea-level fall maximum, and climate cooling. During sea-level fall, the saturation state of the ocean was probably strongly surged by intensive multi-way charging coupled with the cessation of neritic carbonate formation. The increasing limb of the CIE starts at the kozlowski extinction level, with the beginning of lowstand conditions, which probably allowed for the gradual restart of carbonate production. Following the interpretation that the "turning point" marks the end of the glacioeustatic lowstand, the duration of the glacial maximum (starting from the kozlowskii Event) may be estimated at $30 \mathrm{ka}$. Above the "turning point", the coupling of intensive carbonate precipitation (represented by massive whitings) and pronounced $\delta^{13} \mathrm{C}$ increase suggest that the CIE was formed in result of rapid discharge of the supersaturation state during the 45 (assumind the doubled rate of the sedi- mentation of the sparoid-bearing calcisilites) to $90 \mathrm{ka}$ long period of early transgressive conditions.

The presence of eolian material in marine sedimentary rocks is difficult to unequivocal prove. However, in the case of incorporating the terrigenous material into aggregates formed by phytoplankton (in the photic zone) contrasting with the deep-water, anoxic sedimentation, the indication of the presence of the eolian admixture seems to be plausible (Gabbott et al. 2010). On the other hand, such textural composition may result in a reversed interpretation, i.e. the presence of benthic photosynthetic organisms at the dysphotic bottom (Kremer \& Kaźmierczak 2005). A very helpful proxy for arbitrating the uncertain cases would be the presence of water-column formed pyrite framboids occurring exclusively outside of the organic-mineral aggregates (in case of an euxinic environment).

Water-column precipitates could potentially occur also in other Palaeozoic stratigraphic intervals in presumably similar palaeoceanographic conditions. For example, Kaźmierczak et al. (2012) illustrated very similar calcite grains co-occurring with cyanobacterial filaments (interpreted as benthic) in a sulphidic and dysphotic environment from the Frasnian/Fammenian boundary interval of the Holy Cross Mountains in Poland.

The potential of dust-triggered massive pyrite formation for the charging of the ocean saturation state (Kempe 1990), should be reconsidered also in the case of other early Palaeozoic CIEs. A very similar position of pyrite-bearing strata in relation to the mid-Silurian Ireviken Event was presented by McLaughlin et al. (2012). In this case, pyrite accumulation also co-occurred with silt-bearing deposits during an inferred glacial regression. Positive sulphur isotope excursions, interpreted as caused by mass sulphide deposition, have been found in the Hirnantian glaciation interval in South China (Yan et al. 2009) and the Furongian Steptoean Positive Carbon Isotope Excursion (SPICE; Gill et al. 2011). Because pyrite formation is strongly limited by iron availability, the eolian dust driver seems very likely to play an important role in such events.

The "carbonate reflux" model offers a eustacy-driven, simultaneous and effective mechanism of changes of the $\delta^{13} C_{\text {DIC }}$ in individual, spatially detached pools of seawater. The proposed model easily explains the coincidence of the CIEs with carbonate sedimentation maxima, a basinward CIE decline, and the distinct similarities between the CIE increasing limb (e.g. Jeppsson et al. 2007) on the one hand, and potentially local presence of differences in the decreasing limb (by earlier termination of the carbonate factory) on the other hand (see Kozłowski \& Munnecke 2010).

The strong influence of terrigenous carbonate detritus on the bulk-rock isotope signatures, reported in this study, suggests caution in direct interpretation and correlation based on bulk-rock carbon isotope records. 


\section{Acknowledgments}

The paper benefited greatly from the reviews of Jiří Frýda and Carlton Brett, who also greatly helped in language improvements. I thank Anna Żylińska and Mikołaj Zapalski for editorial and language support and anonymous reviewers for constructive comments to an earlier version of the manuscript. I am indebted to Grzegorz Kapron (Warsaw University) for the XRD analyses. Research has been financed by National Science Centre in Poland, Grant NCN No. UMO-2012/05/B/ST10/00571. The paper is a contribution to the IGCP 591 project - The Early to Middle Paleozoic Revolution.

\section{References}

AnToshkinA, A. 2014. Ooid-stromatolite association as a precursor of bioevents (Silurian, Timan-northern Ural Region). Palaeoworld, in press. DOI 10.1016/j.palwor.2014.11.007

Antoshrina, A., Valyaeva, O., Isaenko, S. \& Prots'Ko, O. 2012. Upper Ludfordian black shales as indicators of euxinic conditions, Subpolar Urals. Geochemistry International 50, 1038-1043. DOI 10.1134/S0016702912100023

Armstrong, R.A., Lee, C., Hedges, J.I., Honjo, S. \& Wakeham, S.G. 2001. A new, mechanistic model for organic carbon fluxes in the ocean based on the quantitative association of POC with ballast minerals. Deep Sea Research Part II: Topical Studies in Oceanography 49, 219-236.

DOI 10.1016/S0967-0645(01)00101-1

Arp, G., Reimer, A. \& Reitner, J. 2001. Photosynthesis-induced biofilm calcification and calcium concentrations in Phanerozoic oceans. Science 292, 1701-1704.

DOI 10.1126/science.1057204

Barrick, J.E., Kleffrner, M.A., Gibson, M.A., Peavey, F.N. \& KarLSSON, H.R. 2010. The mid-Ludfordian Lau Event and carbon isotope excursion (Ludlow, Silurian) in southern Laurentia - preliminary results. Bollettino della Società Paleontologica Italiana 49, 13-33.

Baudrand, M., Aloisi, G., Lécuyer, C., Martineau, F., Fourel, F., Escarguel, G., Blanc-Valleron, M.-M., Rouchy, J.-M. \& Grossi, V. 2012. Semi-automatic determination of the carbon and oxygen stable isotope compositions of calcite and dolomite in natural mixtures. Applied Geochemistry 27, 257-265.

DOI 10.1016/j.apgeochem.2011.11.003

BERGER, W.H. \& KEIR, R.S. 1984. Glacial-Holocene changes in atmospheric $\mathrm{CO}_{2}$ and the deep-sea record, 337-351. In Hansen, J.E. \& TAKahashi, T. (eds) Climate Processes and Climate Sensitivity. American Geophysical Union, Washington, DC. DOI 10.1029/GM029p0337

BERNER, R.A. 1975. The role of magnesium in the crystal growth of calcite and aragonite from sea water. Geochimica et Cosmochimica Acta 39, 489-504.

DOI 10.1016/0016-7037(75)90102-7

BERNER, R.A. 1982. Burial of organic carbon and pyrite sulfur in the modern ocean: its geochemical and environmental significance. American Journal of Sciences 282, 451-473. DOI 10.2475/ajs.282.4.451

Bickert, T., PÄtzold, J., Samtleben, C. \& Munnecke, A. 1997. Paleoenvironmental changes in the Silurian indicated by sta- ble isotopes in brachiopod shells from Gotland, Sweden. Geochimica et Cosmochimica Acta 61, 2717-2730.

DOI 10.1016/S0016-7037(97)00136-1

Bond, D., Wignall, P.B. \& RaCKi, G. 2004. Extent and duration of marine anoxia during the Frasnian-Famennian (Late Devonian) mass extinction in Poland, Germany, Austria and France. Geological Magazine 141, 173-193.

DOI $10.1017 /$ S0016756804008866

Bosak, T. \& Newman, D.K. 2005. Microbial kinetic controls on calcite morphology in supersaturated solutions. Journal of Sedimentary Research 75, 190-199.

DOI 10.2110/jsr.2005.015

Boss, S.K. \& Neumann, A.C. 1993. Physical versus chemical processes of "whiting" formation in the Bahamas. Carbonates and Evaporites 8, 135-148. DOI 10.1007/BF03175171

Boss, S.K. \& WiLkinson, B.H. 1991. Planktogenic/eustatic control on cratonic/oceanic carbonate accumulation. The Journal of Geology, 497-513. DOI 10.1086/629513

Bradley, W. 1963. Unmineralized Fossil Bacteria. Science 141, 919-921. DOI 10.1126/science.141.3584.919

Braissant, O., Cailleau, G., Dupraz, C. \& Verrecchia, E.P. 2003. Bacterially induced mineralization of calcium carbonate in terrestrial environments: the role of exopolysaccharides and amino acids. Journal of Sedimentary Research 73, 485-490. DOI 10.1306/111302730485

Brehm, U., Palinska, K.A. \& Krumbein, W.E. 2004. Laboratory cultures of calcifying biomicrospheres generate ooids - A contribution to the origin of oolites. Carnets de Géologie/Notebooks on Geology, Maintenon, Letter 3.

Brett, C.E., Ferretti, A., Histon, K. \& Schönlaub, H.P. 2009. Silurian sequence stratigraphy of the Carnic Alps, Austria. Palaeogeography, Palaeoclimatology, Palaeoecology 279, 1-28. DOI 10.1016/j.palaeo.2009.04.004

Broecker, W., Sanyal, A. \& Takahashi, T. 2000. The origin of Bahamian whitings revisited. Geophysical Research Letters 27, 3759-3760. DOI 10.1029/2000GL011872

BroecKER, W.S. \& TAKAHASHI, T. 1966. Calcium carbonate precipitation on the Bahama Banks. Journal of Geophysical Research 71, 1575-1602. DOI 10.1029/JZ071i006p01575

Brooke, B. 2001. The distribution of carbonate eolianite. Earth-Science Reviews 55, 135-164.

DOI 10.1016/S0012-8252(01)00054-X

Brunskill, G. 1969. Fayetteville Green Lake, New York: Precipitation and sedimentation of calcite in a meromictic lake with laminated sediments. Limnology and Oceanography 14, 830-847. DOI 10.4319/lo.1969.14.6.0830

Brunton, F.R., Smith, L., Dixon, O.A., Copper, P., Nestor, H. \& KERSHAW, S. 1998. Silurian reef episodes, changing seascapes, and paleobiogeography. New York State Museum Bulletin 491, $265-282$.

CALner, M. 2005a. A Late Silurian extinction event and anachronistic period. Geology 33, 305-308. DOI 10.1130/G21185.1

CALner, M. 2005b. A Late Silurian extinction event and anachronistic period: Comment and reply. Geology 33, e92-e92. DOI 10.1130/0091-7613-33.1.e92

CALNER, M. 2005c. Silurian carbonate platforms and extinction events - ecosystem changes exemplified from Gotland, Sweden. Facies 51, 584-591. DOI 10.1007/s10347-005-0050-0

CALner, M. 2008. Silurian global events - at the tipping point of climate change, 21-58. In ElewA, A.M.T. (ed.) Mass extinction. Springer-Verlag, Heidelberg. 
Carroll, A.R., Stephens, N.P., Hendrix, M.S. \& Glenn, C.R. 1998. Eolian-derived siltstone in the Upper Permian Phosphoria Formation: implications for marine upwelling. Geology 26, 1023-1026. DOI 10.1130/0091-7613(1998)026<1023:EDSITU>2.3.CO;2

Chekroun, K.B., Rodríguez-Navarro, C., González-Muñoz, M.T., Arias, J.M., Cultrone, G. \& Rodríguez-Gallego, M. 2004. Precipitation and growth morphology of calcium carbonate induced by Myxococcus xanthus: implications for recognition of bacterial carbonates. Journal of Sedimentary Research 74, 868-876. DOI 10.1306/050504740868

Cherns, L. 1982. Palaeokarst, tidal erosion surfaces and stromatolites in the Silurian Eke Formation of Gotland, Sweden. Sedimentology 29, 819-833. DOI 10.1111/j.1365-3091.1982.tb00086.x

Cherns, L. \& Wheeley, J.R. 2009. Early Palaeozoic cooling events: peri-Gondwana and beyond. Geological Society of London, Special Publications 325, 257-278. DOI 10.1144/SP325.13

Clemens, S.C. 1998. Dust response to seasonal atmospheric forcing: Proxy evaluation and calibration. Paleoceanography 13, 471-490. DOI 10.1029/98PA02131

Cloud, P. 1962. Environment of calcium carbonate deposition west of Andros Island, Bahamas. US Government Printing Office.

Cramer, B.D., Loydell, D.K., Samtleben, C., Munnecke, A., Kaljo, D., Männik, P., Martma, T., Jeppsson, L., Kleffner, M.A. \& BARrick, J.E. 2010. Testing the limits of Paleozoic chronostratigraphic correlation via high-resolution $(<500 \mathrm{ky})$ integrated conodont, graptolite, and carbon isotope $\left(\delta^{13} \mathrm{C}_{\text {carb }}\right)$ biochemostratigraphy across the Llandovery-Wenlock (Silurian) boundary: Is a unified Phanerozoic time scale achievable? Geological Society of America Bulletin 122, 1700-1716. DOI 10.1130/B26602.1

Cramer, B.D. \& Munnecke, A. 2008. Early Silurian positive $\delta^{13} \mathrm{C}$ excursions and their relationship to glaciations, sea-level changes and extinction events: discussion. Geological Journal 43, 517. DOI 10.1002/gj.1112

Curry, B.B., Anderson, T.F. \& Lohmann, K.C. 1997. Unusual carbon and oxygen isotopic ratios of ostracodal calcite from last interglacial (Sangamon episode) lacustrine sediment in Raymond Basin, Illinois, USA. Journal of Paleolimnology 17, 421-435. DOI 10.1023/A:1007964917875

Davies, G.R., Moslow, T.F. \& Sherwin, M.D. 1997. The lower Triassic Montney formation, west-central Alberta. Bulletin of Canadian Petroleum Geology 45, 474-505.

Dickson, J.A.D. 1965. A modified staining technique for carbonates in thin section. Nature 205, 587. DOI 10.1038/205587a0

DitTrich, M., Kurz, P. \& Wehrli, B. 2004. The role of autotrophic picocyanobacteria in calcite precipitation in an oligotrophic lake. Geomicrobiology Journal 21, 45-53. DOI 10.1080/01490450490253455

DitTrich, M. \& OBst, M. 2004. Are picoplankton responsible for calcite precipitation in lakes? AMBIO: A Journal of the $\mathrm{Hu}$ man Environment 33, 559-564.

Donar, C., Condon, K., Gantar, M. \& Gaiser, E. 2004. A new technique for examining the physical structure of Everglades floating periphyton mat. Nova Hedwigia 78, 107-119. DOI 10.1127/0029-5035/2004/0078-0107

Dromgoole, E.L. \& Walter, L.M. 1990. Iron and manganese incorporation into calcite: Effects of growth kinetics, tempera- ture and solution chemistry. Chemical Geology 81, 311-336. DOI 10.1016/0009-2541(90)90053-A

Duce, R.A. \& Tindale, N.W. 1991. Atmospheric transport of iron and its deposition in the ocean. Limnology and Oceanography 36, 1715-1726. DOI 10.4319/lo.1991.36.8.1715

Eriksson, M.J. \& CALnER, M. 2008. A sequence stratigraphical model for the Late Ludfordian (Silurian) of Gotland, Sweden: implications for timing between changes in sea level, palaeoecology, and the global carbon cycle. Facies 54, 253-276. DOI 10.1007/s10347-007-0128-y

FALKOwsKi, P.G. 1997. Evolution of the nitrogen cycle and its influence on the biological sequestration of $\mathrm{CO}_{2}$ in the ocean. Nature 387, 272-275. DOI 10.1038/387272a0

Fischer, A.G. \& SARNTHEIN, M. 1988. Airborne silts and dune-derived sands in the Permian of the Delaware Basin. Journal of Sedimentary Research 58, 637-643.

Fischer, G., Karakas, G., Blaas, M., Ratmeyer, V., Nowald, N., Schlitzer, R., Helmke, P., Davenport, R., Donner, B. \& Neuer, S. 2009. Mineral ballast and particle settling rates in the coastal upwelling system off NW Africa and the South Atlantic. International Journal of Earth Sciences 98, 281-298. DOI 10.1007/s00531-007-0234-7

FLüGEL, E. 2004. Microfacies of Carbonate Rocks, Analysis, Interpretation and Application. 976 pp. Springer Verlag, Berlin.

Fornós, J.J., Gines, J. \& GrÀCIA, F. 2009. Present-day sedimentary facies in the coastal karst caves of Mallorca Island (Western Mediterranean). Journal of Cave and Karst Studies 71, 86-99.

FRÝDA, J. \& MANDA, S̆. 2013. A long-lasting steady period of isotopically heavy carbon in the late Silurian ocean: evolution of the $\delta^{13} \mathrm{C}$ record and its significance for an integrated $\delta^{13} \mathrm{C}$, graptolite and conodont stratigraphy. Bulletin of Geosciences 88, 463-482. DOI 10.3140/bull.geosci.1436

Gabbott, S.E., Zalasiewicz, J., Aldridge, R.J. \& Theron, J.N. 2010. Eolian input into the Late Ordovician postglacial Soom Shale, South Africa. Geology 38, 1103-1106. DOI 10.1130/G31426.1

Ghienne, J.-F., Desrochers, A., Vandenbroucke, T.R., Achab, A., Asselin, E., Dabard, M.-P., Farley, C., Loi, A., Paris, F. \& Wickson, S. 2014. A Cenozoic-style scenario for the end-Ordovician glaciation. Nature Communications 5(4485). DOI 10.1038/ncomms5485

Gill, B.C., Lyons, T.W., Young, S.A., Kump, L.R., Knoll, A.H. \& Saltzman, M.R. 2011. Geochemical evidence for widespread euxinia in the Later Cambrian ocean. Nature 469, 80-83. DOI 10.1038/nature09700

Gischler, E., Swart, P.K. \& Lomando, A.J. 2007. Stable isotopes of carbon and oxygen in modern sediments of carbonate platforms, barrier reefs, atolls, and ramps: patterns and implications. International Association of Sedimentologists Special Publication 41, 61-74.

Gocke, M., Lehnert, O. \& FrÝdA, J. 2013. Facies development and palynomorphs during the Lau Event (Late Silurian) in a non-tropical carbonate environment: shallow and deep water examples from the Barrandian Area (Czech Republic). Facies 59, 611-630. DOI 10.1007/s10347-012-0328-y

Harzhauser, M., Piller, W.E. \& Latal, C. 2007. Geodynamic impact on the stable isotope signatures in a shallow epicontinental sea. Terra Nova 19, 324-330.

DOI 10.1111/j.1365-3121.2007.00755.x 
Hassan, K.M. 2014. Isotope geochemistry of Swan Lake Basin in the Nebraska Sandhills, USA: Large ${ }^{13} \mathrm{C}$ enrichment in sediment-calcite records. Chemie der Erde - Geochemistry 74, 681-690. DOI 10.1016/j.chemer.2014.03.004

Henjes, J. \& Assmy, P. 2008. Particle availability controls agglutination in pelagic tintinnids in the Southern Ocean. Protist 159, 239-250. DOI 10.1016/j.protis.2007.10.003

Hodell, D.A., Schelske, C.L., Fahnenstiel, G.L. \& Robbins, L.L. 1998. Biologically induced calcite and its isotopic composition in Lake Ontario. Limnology and Oceanography 43, 187-199. DOI 10.4319/lo.1998.43.2.0187

Holmden, C., Creaser, R., Muehlenbachs, K., Leslie, S. \& Bergström, S. 1998. Isotopic evidence for geochemical decoupling between ancient epeiric seas and bordering oceans: Implications for secular curves. Geology 26, 567-570.

DOI 10.1130/0091-7613(1998)026<0567:IEFGDB >2.3.CO;2

Holmden, C., Panchuk, K. \& Finney, S. 2012. Tightly coupled records of $\mathrm{Ca}$ and $\mathrm{C}$ isotope changes during the Hirnantian glaciation event in an epeiric sea setting. Geochimica et Cosmochimica Acta 98, 94-106.

DOI 10.1016/j.gca.2012.09.017

Hu, X. \& CAI, W.J. 2011. An assessment of ocean margin anaerobic processes on oceanic alkalinity budget. Global Biogeochemical Cycles 25. DOI 10.1029/2010gb003859

JAEGER, H. 1975. Die Graptolithenführung im Silur/Devon des Cellon-Profils (Karnische Alpen). Ein Beitrag zur Gleichsetzung der Conodonten-und Graptolithenzonen des Silurs. Carinthia II, 85, 111-126.

JEPPSSON, L. 1990. An oceanic model for lithological and faunal changes tested on the Silurian record. Journal of the Geological Society 147, 663-674. DOI 10.1144/gsjgs.147.4.0663

JEPPSSOn, L. \& AldRIDGE, R.J. 2000. Ludlow (late Silurian) oceanic episodes and events. Journal of the Geological Society 157, 1137-1148. DOI 10.1144/jgs.157.6.1137

Jeppsson, L., Talent, J.A., Mawson, R., Andrew, A., Corradini, C., Simpson, A.J., Wigforss-Lange, J. \& Schönlaub, H.P. 2012. Late Ludfordian correlation and the Lau Event, 653-675. In TALENT, J.A. (ed.) Earth and Life, International Year of Planet Earth. Springer Verlag, Heidelberg. DOI 10.1007/978-90-481-3428-1_21

Jeppsson, L., Talent, J.A., Mawson, R., Simpson, A.J., Andrew, A.S., Calner, M., Whitford, D.J., Trotter, J.A., SAndström, O. \& CALDON, H.-J. 2007. High-resolution Late Silurian correlations between Gotland, Sweden, and the Broken River region, NE Australia: lithologies, conodonts and isotopes. Palaeogeography, Palaeoclimatology, Palaeoecology 245, 115-137. DOI 10.1016/j.palaeo.2006.02.032

JoNES, B. 1989. Calcite rafts, peloids, and micrite in cave deposits from Cayman Brae, British West Indies. Canadian Journal of Earth Sciences 26, 654-664. DOI 10.1139/e89-056

Kaljo, D., Martma, T., MÄnnik, P. \& ViIRA, V. 2003. Implications of Gondwana glaciations in the Baltic late Ordovician and Silurian and a carbon isotopic test of environmental cyclicity. Bulletin de la Société géologique de France 174, 59-66. DOI 10.2113/174.1.59

KaŹmiercZaK, J., Kremer, B. \& Racki, G. 2012. Late Devonian marine anoxia challenged by benthic cyanobacterial mats. Geobiology 10, 371-383.

DOI 10.1111/j.1472-4669.2012.00339.x

Kearsey, T., Twitchett, R.J. \& Newell, A.J. 2012. The origin and significance of pedogenic dolomite from the Upper Perm- ian of the South Urals of Russia. Geological Magazine 149, 291-307. DOI 10.1017/S0016756811000926

KeMPE, S. 1990. Alkalinity: the link between anaerobic basins and shallow water carbonates? Naturwissenschaften 77, 426-427. DOI 10.1007/BF01135940

Kempe, S. \& KAŹMIERCZAK, J. 1990. Calcium carbonate supersaturation and the formation of in situ calcified stromatolites, 255-278. In Ittekot, V., Kempe, S., Michaelis, W. \& Sitzzy, A. (eds) Facets of Modern Biogeochemistry. Springer-Verlag, Berlin. DOI 10.1007/978-3-642-73978-1_21

Kempe, S. \& KAŹMiercZAK, J. 1993. Satonda Crater Lake, Indonesia: Hydrogeochemistry and biocarbonates. Facies 28, 1-31. DOI 10.1007/BF02539726

Kempe, S. \& KAźmierCZAK, J. 1994. The role of alkalinity in the evolution of ocean chemistry, organization of living systems, and biocalcification processes. Bulletin de l'Institut océanographique, 61-117.

Khalaf, F., Al-Saleh, S., Al-Houty, F., Ansari, L. \& Shublaq, W. 1979. Mineralogy and grain size distribution of dust fallout in Kuwait. Atmospheric Environment (1967) 13, 1719-1723. DOI 10.1016/0004-6981(79)90334-2

KHAN, A.A. 1997. Quartz and dolomite content variations and climate changes in late Pleistocene sediments of the North Arabian Sea. Geological Bulletin, University of Peshawar 30, $1-11$.

KlaAs, C. \& ARCher, D.E. 2002. Association of sinking organic matter with various types of mineral ballast in the deep sea: Implications for the rain ratio. Global Biogeochemical Cycles 16, 63-1-63-14.

KLEYPAS, J. 1997. Modeled estimates of global reef habitat and carbonate production since the last glacial maximum. Paleoceanography 12, 533-545.

DOI 10.1029/97PA01134

KozŁowsKi, W. 2003. Age, sedimentary environment and palaeogeographical position of the Late Silurian oolitic beds in the Holy Cross Mountains (Central Poland). Acta Geologica Polonica 53, 341-357.

KozŁowsKi, W. 2008. Lithostratigraphy and Regional Significance of the Nowa Słupia Group (Upper Silurian) of the Łysogóry Region (Holy Cross Mountains, Central Poland). Acta Geologica Polonica 58, 43-74.

KozŁowski, W., Domańska-SiUdA, J. \& NAWRocki, J. 2014. Geochemistry and petrology of the upper Silurian greywackes from the Holy Cross Mountains (Central Poland): implications for the Caledonian history of the southern part of the Trans-European Suture Zone (TESZ). Geological Quarterly 58, 311-336. DOI 10.7306/gq.1160

KozŁowski, W. \& MunNeCKE, A. 2010. Stable carbon isotope development and sea-level changes during the Late Ludlow (Silurian) of the Łysogóry region (Rzepin section, Holy Cross Mountains, Poland). Facies 56, 615-633.

DOI 10.1007/s10347-010-0220-6

KozŁowski, W. \& Sobień, K. 2012. Mid-Ludfordian coeval carbon isotope, natural gamma ray and magnetic susceptibility excursions in the Mielnik IG-1 borehole (Eastern Poland) dustiness as a possible link between global climate and the $\mathrm{Si}$ lurian carbon isotope record. Palaeogeography, Palaeoclimatology, Palaeoecology 339, 74-97.

DOI 10.1016/j.palaeo.2012.04.024

Kremer, B. \& KażmierczaK, J. 2005. Cyanobacterial mats from Silurian black radiolarian cherts: phototrophic life at the edge 
of darkness? Journal of Sedimentary Research 75, 897-906. DOI 10.2110/jsr.2005.069

Ǩ̌iž, J. 1991. The Silurian of the Prague Basin (Bohemia) - tectonic, eustatic and volcanic controls on facies and faunal development, 179-203. In Bassett, M.G., LANE, P.D. \& EDwards, D. (eds) The Murchison Symposium: Proceedings of an International Conference on The Silurian System. Special Papers in Palaeontology 44.

Kump, L., Arthur, M., Patzkowsky, M., Gibbs, M., Pinkus, D. \& SHEEHAN, P. 1999. A weathering hypothesis for glaciation at high atmospheric $p \mathrm{CO}_{2}$ during the Late Ordovician. Palaeogeography, Palaeoclimatology, Palaeoecology 152, 173-187. DOI 10.1016/S0031-0182(99)00046-2

LaPorte, D., Holmden, C., Patterson, W., Loxton, J., Melchin, M., Mitchell, C., Finney, S. \& Sheets, H. 2009. Local and global perspectives on carbon and nitrogen cycling during the Hirnantian glaciation. Palaeogeography, Palaeoclimatology, Palaeoecology 276, 182-195.

DOI 10.1016/j.palaeo.2009.03.009

Lehnert, O., Eriksson, M., Calner, M., Joachimski, M. \& BugGisch, W. 2007a. Concurrent sedimentary and isotopic indications for global climatic cooling in the Late Silurian. Acta Palaeontologica Sinica 46, 249.

Lehnert, O., Frýda, J., Buggisch, W., Munnecke, A., Nützel, A., KŘižz, J. \& MANDA, S. 2007b. $\delta^{13}$ C records across the late Silurian Lau event: New data from middle palaeo-latitudes of northern peri-Gondwana (Prague Basin, Czech Republic). Palaeogeography, Palaeoclimatology, Palaeoecology 245, 227-244. DOI 10.1016/j.palaeo.2006.02.022

Li, W., Liu, L.-P., Zhou, P.-P., CaO, L., Yu, L.-J. \& Jiang, S.-Y. 2011. Calcite precipitation induced by bacteria and bacterially produced carbonic anhydrase. Current Science (Bangalore) $100,502-508$

Lipps, J. H., Stoeck, T., \& Dunthorn, M. 2013. Fossil tintinnids, 186-197. In Dolan, J.R., Montagnes, D.J.S., Agatha, S., CoAts, D.W. \& Stoecker, D.K. (eds) Biology and ecology of tintinnid ciliates: models for marine plankton. WileyBlackwell, West Sussex.

Loope, D.B. \& HaverLand, Z.E. 1988. Giant desiccation fissures filled with calcareous eolian sand, Hermosa Formation (Pennsylvanian), southeastern Utah. Sedimentary Geology 56, 403-413. DOI 10.1016/0037-0738(88)90063-2

LoydelL, D.K. 2007. Early Silurian positive $\delta^{13} \mathrm{C}$ excursions and their relationship to glaciations, sea-level changes and extinction events. Geological Journal 42, 531-546. DOI $10.1002 / \mathrm{gj} .1090$

LYDAL, J.R. 1985. Atokan (Pennsylvanian) Berlin Field: genesis of recycled detrital dolomite reservoir, deep Anadarko Basin, Oklahoma. American Association of Petroleum Geologists Bulletin 69, 1931-1949.

Lynch-Stieglitz, J., Stocker, T.F., Broecker, W.S. \& FairBANKS, R.G. 1995. The influence of air-sea exchange on the isotopic composition of oceanic carbon: Observations and modeling. Global Biogeochemical Cycles 9, 653-665. DOI 10.1029/95GB02574

Maher, B., Prospero, J., Mackie, D., Gaiero, D., Hesse, P. \& BALKANSKI, Y. 2010. Global connections between aeolian dust, climate and ocean biogeochemistry at the present day and at the last glacial maximum. Earth-Science Reviews 99, 61-97. DOI 10.1016/j.earscirev.2009.12.001

Martin, J.H. \& Fitzwater, S. 1988. Iron deficiency limits phytoplankton growth in the north-east Pacific subarctic. $\mathrm{Na}$ ture 331, 947-975. DOI 10.1038/331341a0

Martire, L., Bertok, C., D’atri, A., Perotti, E. \& Piana, F. 2014. Selective dolomitization by syntaxial overgrowth around detrital dolomite nuclei: a case from the Jurassic of the Ligurian Briançonnais (Ligurian Alps). Journal of Sedimentary Research 84, 40-50. DOI 10.2110/jsr.2014.2

Martma, T., Brazauskas, A., Kaljo, D., Kaminskas, D. \& Musteikis, P. 2010. The Wenlock-Ludlow carbon isotope trend in the Vidukle core, Lithuania, and its relations with oceanic events. Geological Quarterly 49, 223-234.

McFadden, L.D., McDonald, E.V., Wells, S.G., Anderson, K., QuADE, J. \& FoRMAN, S.L. 1998. The vesicular layer and carbonate collars of desert soils and pavements: formation, age and relation to climate change. Geomorphology 24, 101-145. DOI 10.1016/S0169-555X(97)00095-0

McLaughlin, P.I., Emsbo, P. \& BREtT, C.E. 2012. Beyond black shales: the sedimentary and stable isotope records of oceanic anoxic events in a dominantly oxic basin (Silurian; Appalachian Basin, USA). Palaeogeography, Palaeoclimatology, Palaeoecology 367, 153-177. DOI 10.1016/j.palaeo.2012.10.002

Melchin, M.J. \& Holmden, C. 2006. Carbon isotope chemostratigraphy in Arctic Canada: sea-level forcing of carbonate platform weathering and implications for Hirnantian global correlation. Palaeogeography, Palaeoclimatology, Palaeoecology 234, 186-200.

DOI 10.1016/j.palaeo.2005.10.009

MEYER, H. 1984. The influence of impurities on the growth rate of calcite. Journal of Crystal Growth 66, 639-646. DOI 10.1016/0022-0248(84)90164-7

Milliman, J.D., Freile, D., Steinen, R.P. \& Wilber, R.J. 1993. Great Bahama Bank aragonitic muds: mostly inorganically precipitated, mostly exported. Journal of Sedimentary Research 63.

Modzalevskaja, T. \& Wenzel, B. 1999. Biostratigraphy and geochemistry of Upper Silurian brachiopods from the Timan-Pechora region (Russia). Acta Geologica Polonica 49, $145-157$.

Morse, J.W., Gledhill, D.K. \& Millero, F.J. 2003. $\mathrm{CaCO}_{3}$ precipitation kinetics in waters from the great Bahama bank: Implications for the relationship between bank hydrochemistry and whitings. Geochimica et Cosmochimica Acta 67, 2819-2826. DOI 10.1016/S0016-7037(03)00103-0

Morse, J.W. \& He, S. 1993. Influences of $T, S$ and $P_{\mathrm{CO} 2}$ on the pseudo-homogeneous precipitation of $\mathrm{CaCO}_{3}$ from seawater: implications for whiting formation. Marine Chemistry 41, 291-297. DOI 10.1016/0304-4203(93)90261-L

Morse, J.W., Millero, F.J., Thurmond, V., Brown, E. \& OstLund, H. 1984. The carbonate chemistry of Grand Bahama Bank waters: after 18 years another look. Journal of Geophysical Research 89, 3604-3614. DOI 10.1029/JC089iC03p03604

Munnecke, A., Calner, M., Harper, D.A. \& Servais, T. 2010. Ordovician and Silurian sea-water chemistry, sea level, and climate: A synopsis. Palaeogeography, Palaeoclimatology, Palaeoecology 296, 389-413. DOI 10.1016/j.palaeo.2010.08.001

Munnecke, A., SAmtleben, C. \& Bickert, T. 2003. The Ireviken Event in the lower Silurian of Gotland, Sweden - relation to similar Palaeozoic and Proterozoic events. Palaeogeography, 
Palaeoclimatology, Palaeoecology 195, 99-124. DOI 10.1016/S0031-0182(03)00304-3

Murray, J. \& TAYLOR, F. 1965. Early calpionellids from the Upper Devonian of western Canada, with a note on pyrite inclusions. Bulletin of Canadian Petroleum Geology 13, 327-334.

Naiman, Z., Quade, J. \& PatchetT, P.J. 2000. Isotopic evidence for eolian recycling of pedogenic carbonate and variations in carbonate dust sources throughout the southwest United States. Geochimica et Cosmochimica Acta 64, 3099-3109. DOI 10.1016/S0016-7037(00)00410-5

Nakai, N., Wada, H., KiYosu, Y. \& Takimoto, M. 1975. Stable isotope studies on the origin and geological history of water and salts in the Lake Vanda area, Antarctica. Geochemical Journal 9, 7-24. DOI 10.2343/geochemj.9.7

Ова, T. \& Pedersen, T.F. 1999. Paleoclimatic significance of eolian carbonates supplied to the Japan Sea during the last glacial maximum. Paleoceanography 14, 34-41.

DOI 10.1029/98PA02507

Ohlendorf, C. \& Sturm, M. 2001. Precipitation and dissolution of calcite in a Swiss high alpine lake. Arctic, Antarctic, and Alpine Research 33, 410-417. DOI 10.2307/1552550

OnAC, B.P. 1997. Crystallography of speleothems, 230-235. In Hill, C. \& Forti CAve, P. (eds) Minerals of the World. $2^{\text {nd }}$ edition. National Speleological Society, Alabama, USA.

OPdYKe, B.N. \& WALKER, J.C. 1992. Return of the coral reef hypothesis: Basin to shelf partitioning of $\mathrm{CaCO}_{3}$ and its effect on atmospheric $\mathrm{CO}_{2}$. Geology 20, 733-736. DOI 10.1130/0091-7613(1992)020<0733:ROTCRH >2.3.CO;2

Peryt, T.M. \& Peryt, D. 2012. Geochemical and foraminiferal records of environmental changes during the Zechstein Limestone (Lopingian) deposition in Northern Poland. Geological Quarterly 56, 187-198.

PoręBSKi, S.J., Prugar, W. \& Zacharski, J. 2013. Silurian shales of the East European Platform in Poland - some exploration problems. Przeglad Geologiczny 61, 630-638.

Pytkowicz, R.M. 1965. Rates of inorganic calcium carbonate nucleation. The Journal of Geology 73, 196-199. DOI 10.1086/627056

Quade, J., Rech, J.A., Latorre, C., Betancourt, J.L., Gleeson, E. \& KALIN, M.T. 2007. Soils at the hyperarid margin: The isotopic composition of soil carbonate from the Atacama Desert, Northern Chile. Geochimica et Cosmochimica Acta 71, 3772-3795. DOI 10.1016/j.gca.2007.02.016

Raiswell, R. \& Berner, R.A. 1985. Pyrite formation in euxinic and semi-euxinic sediments. American Journal of Science 285, 710-724. DOI 10.2475/ajs.285.8.710

RaO, D.S., Al-Yamani, F. \& RaO, C.N. 1999. Eolian dust affects phytoplankton in the waters off Kuwait, the Arabian Gulf. Naturwissenschaften 86, 525-529.

DOI $10.1007 / \mathrm{s} 001140050667$

Ridgwell, A.J., Kennedy, M.J. \& CAldeira, K. 2003. Carbonate deposition, climate stability, and Neoproterozoic ice ages. Science 302(5646), 859-862.

DOI $10.1126 /$ science. 1088342

Ridgwell, A. \& ZEeBE, R.E. 2005. The role of the global carbonate cycle in the regulation and evolution of the Earth system. Earth and Planetary Science Letters 234, 299-315. DOI 10.1016/j.epsl.2005.03.006

RIDING, R. 2005. A Late Silurian extinction event and anachronistic period: Comment and reply. Geology 33, e91.

DOI 10.1130/0091-7613-33.1.e91
RIDING, R. 2006. Cyanobacterial calcification, carbon dioxide concentrating mechanisms, and Proterozoic-Cambrian changes in atmospheric composition. Geobiology 4, 299-316. DOI 10.1111/j.1472-4669.2006.00087.x

RidinG, R. \& LiANG, L. 2005a. Geobiology of microbial carbonates: metazoan and seawater saturation state influences on secular trends during the Phanerozoic. Palaeogeography, Palaeoclimatology, Palaeoecology 219, 101-115.

DOI 10.1016/j.palaeo.2004.11.018

RidinG, R. \& LiANG, L. 2005b. Seawater chemistry control of marine limestone accumulation over the past 550 million years. Revista Española de Micropaleontología 37, 1-11.

Robbins, L. \& Blackwelder, P. 1992. Biochemical and ultrastructural evidence for the origin of whitings: a biologically induced calcium carbonate precipitation mechanism. Geology 20, 464-468.

DOI 10.1130/0091-7613(1992)020<0464:BAUEFT>2.3.CO;2

Robins, L., TAO, Y. \& Evans, C. 1997. Temporal and spatial distribution of whitings on Great Bahama Bank and a new lime mud budget. Geology 25, 947-950.

DOI 10.1130/0091-7613(1997)025<0947:TASDOW >2.3.CO;2

Rosenbaum, J. \& Sheppard, S. 1986. An isotopic study of siderites, dolomites and ankerites at high temperatures. Geochimica et Cosmochimica Acta 50, 1147-1150.

DOI 10.1016/0016-7037(86)90396-0

Samtleben, C., Munnecke, A. \& Bickert, T. 2000. Development of facies and $\mathrm{C} / \mathrm{O}$-isotopes in transects through the Ludlow of Gotland: evidence for global and local influences on a shallow-marine environment. Facies 43, 1-38.

DOI 10.1007/BF02536983

Samtleben, C., Munnecke, A., Bickert, T. \& Pätzold, J. 1996. The Silurian of Gotland (Sweden): facies interpretation based on stable isotopes in brachiopod shells. Geologische Rundschau 85, 278-292. DOI 10.1007/BF02422234

SANDBERG, P.A. 1983. An oscillating trend in Phanerozoic nonskeletal carbonate mineralogy. Nature 305, 19-22. DOI 10.1038/305019a0

SchÖNLAUB, H.P. 1986. Significant geological events in the Paleozoic record of the Southern Alps (Austrian part), 161-167. In WALliser, O.H. (ed.) Global bio-events. Springer-Verlag, Berlin \& Heidelberg. DOI 10.1007/BFb0010201

Shinn, E.A., Steinen, R.P., Lidz, B.H. \& Swart, P.K. 1989. Whitings, a sedimentologic dilemma. Journal of Sedimentary Research 59, 147-161.

DOI 10.1306/212f8f3a-2b24-11d7-8648000102c1865d

SorEghAN, G.S. 1992. Preservation and paleoclimatic significance of eolian dust in the Ancestral Rocky Mountains province. Geology 20, 1111-1114.

DOI 10.1130/0091-7613(1992)020<1111:PAPSOE >2.3.CO;2

Soreghan, G.S. \& Soreghan, M.J. 2002. Atmospheric dust and algal dominance in the late Paleozoic: a hypothesis. Journal of Sedimentary Research 72, 457-461.

DOI 10.1306/011102720457

Stabel, H.H. 1986. Calcite precipitation in Lake Constance: Chemical equilibrium, sedimentation, and nucleation by algae1. Limnology and Oceanography 31, 1081-1094. DOI 10.4319/lo.1986.31.5.1081

Stel, J.H. \& DE Coo, J.C. 1977. The Silurian Upper Burgsvik and Lower Hamra-Sundre Beds, Gotland. Scripta Geologica 44, $1-43$.

Stricanne, L., Munnecke, A. \& Pross, J. 2006. Assessing mech- 
anisms of environmental change: Palynological signals across the Late Ludlow (Silurian) positive isotope excursion $\left(\delta^{13} \mathrm{C}\right.$, $\left.\delta^{18} \mathrm{O}\right)$ on Gotland, Sweden. Palaeogeography, Palaeoclimatology, Palaeoecology 230, 1-31. DOI 10.1016/j.palaeo.2005.07.003

Strong, A.E. \& Eadie, B.J. 1978. Satellite observations of calcium carbonate precipitations in the Great Lakes. Limnology and Oceanography 23, 877-887. DOI 10.4319/lo.1978.23.5.0877

StuUt, J.-B.W. 2014. Subaquatic Dust Deposits, 443-462. In KnipPertz, P. \& StuUt, J.-B.W. (eds) Mineral Dust. Springer, Netherlands. DOI 10.1007/978-94-017-8978-3_17

Sumner, D.Y. \& Grotzinger, J.P. 1996. Were kinetics of Archean calcium carbonate precipitation related to oxygen concentration? Geology 24, 119-122.

DOI 10.1130/0091-7613(1996)024<0119:WKOACC >2.3.CO;2

Swart, P., Oehlert, A., Mackenzie, G., Eberli, G. \& Reijmer, J. 2014. The fertilization of the Bahamas by Saharan dust: A trigger for carbonate precipitation? Geology 42, 671-674. DOI 10.1130/G35744.1

SwART, P.K. 2008. Global synchronous changes in the carbon isotopic composition of carbonate sediments unrelated to changes in the global carbon cycle. Proceedings of the $\mathrm{Na}$ tional Academy of Sciences 105, 13741-13745. DOI 10.1073/pnas.0802841105

Talent, J.A., Mawson, R., Andrew, A.S., Hamilton, P.J. \& Whitford, D.J. 1993. Middle Palaeozoic extinction events: faunal and isotopic data. Palaeogeography, Palaeoclimatology, Palaeoecology 104, 139-152.

DOI 10.1016/0031-0182(93)90126-4

Taylor, M., Drysdale, R. \& CARTHEw, K. 2004. The formation and environmental significance of calcite rafts in tropical tufa - depositing rivers of northern Australia. Sedimentology 51, 1089-1101. DOI 10.1111/j.1365-3091.2004.00661.x

Thompson, J.B. 2000. Microbial whitings, 250-260. In Riding, R.E. \& AwramiK, S.M. (eds) Microbial Sediments. SpringerVerlag, Berlin \& Heidelberg.

DOI 10.1007/978-3-662-04036-2_27

ThOMpson, J.B. \& Ferris, F. 1990. Cyanobacterial precipitation of gypsum, calcite, and magnesite from natural alkaline lake water. Geology 18, 995-998.

DOI 10.1130/0091-7613(1990)018<0995:CPOGCA >2.3.CO;2

Thompson, J.B., Schultze-Lam, S., Beveridge, T.J. \& Des MaraIs, D.J. 1997. Whiting events: biogenic origin due to the photosynthetic activity of cyanobacterial picoplankton. Limnology and Oceanography 42, 133-141.

DOI 10.4319/lo.1997.42.1.0133
URbanek, A. 1970. Neocucullograptinae n. subfam. (Graptolithina) - their evolutionary and stratigraphic bearing. Acta Palaeontologica Polonica 15, 163-388.

UrbaneK, A. 1993. Biotic crises in the history of Upper Silurian graptoloids: a palaeobiological model. Historical Biology 7, 29-50. DOI 10.1080/10292389309380442

Urbanek, A. 1997. Late Ludfordian and early Pridoli monograptids from the Polish Lowland. Acta Palaeontologica Polonica 56, 87-231.

Valero-Garcés, B.L., Delgado-Huertas, A., Ratto, N. \& Navas, A. 1999. Large ${ }^{13} \mathrm{C}$ enrichment in primary carbonates from Andean Altiplano lakes, northwest Argentina. Earth and Planetary Science Letters 171, 253-266.

DOI 10.1016/S0012-821X(99)00150-8

WAINRIGHT, S.C. 1987. Stimulation of heterotrophic microplankton production by resuspended marine sediments. Science $238,1710-1712$. DOI 10.1126/science.238.4834.1710

WARREN, J. 2000. Dolomite: occurrence, evolution and economically important associations. Earth-Science Reviews 52, 1-81. DOI 10.1016/S0012-8252(00)00022-2

Wells, A. \& Illing, L. 1964. Present day precipitation of calcium carbonate in the Persian Gulf, 429-435. In Van StraAten, L.M.J.U. (ed.) Developments in Sedimentology 1, Deltaic and Shallow Marine Deposits. Elsevier, Amsterdam. DOI 10.1016/S0070-4571(08)70517-X

Wigforss-Lange, J. 1999. Carbon isotope ${ }^{13} \mathrm{C}$ enrichment in Upper Silurian (Whitcliffian) marine calcareous rocks in Scania, Sweden. GFF 121, 273-279.

DOI 10.1080/11035899901214273

Wigforss-Lange, J. 2007. Tidal facies in the Upper Silurian Öved-Ramsåsa Group of Scania, Sweden: Linkages of radial and cerebroid ooids and evaporite tracers to subtidal, lagoonal environment. GFF 129, 7-16.

DOI 10.1080/11035890701291007

Wignall, P. \& Newton, R. 1998. Pyrite framboid diameter as a measure of oxygen deficiency in ancient mudrocks. American Journal of Science 298, 537-552. DOI 10.2475/ajs.298.7.537

Wilkin, R.T., BARNes, H.L. \& BRANTLEy, S.L. 1996. The size distribution of framboidal pyrite in modern sediments: An indicator of redox conditions. Geochimica et Cosmochimica Acta 60, 3897-3912. DOI 10.1016/0016-7037(96)00209-8

YAN, D., ChEN, D., WANG, Q., WANG, J. \& WANG, Z. 2009. Carbon and sulfur isotopic anomalies across the Ordovician-Silurian boundary on the Yangtze Platform, South China. Palaeogeography, Palaeoclimatology, Palaeoecology 274, 32-39. DOI 10.1016/j.palaeo.2008.12.016 